$$
\begin{aligned}
& \text { 楛 }
\end{aligned}
$$

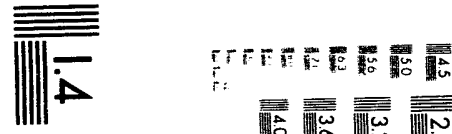

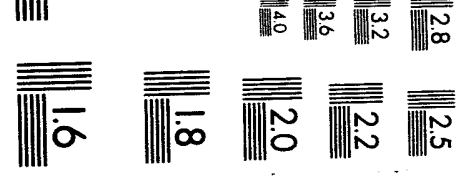



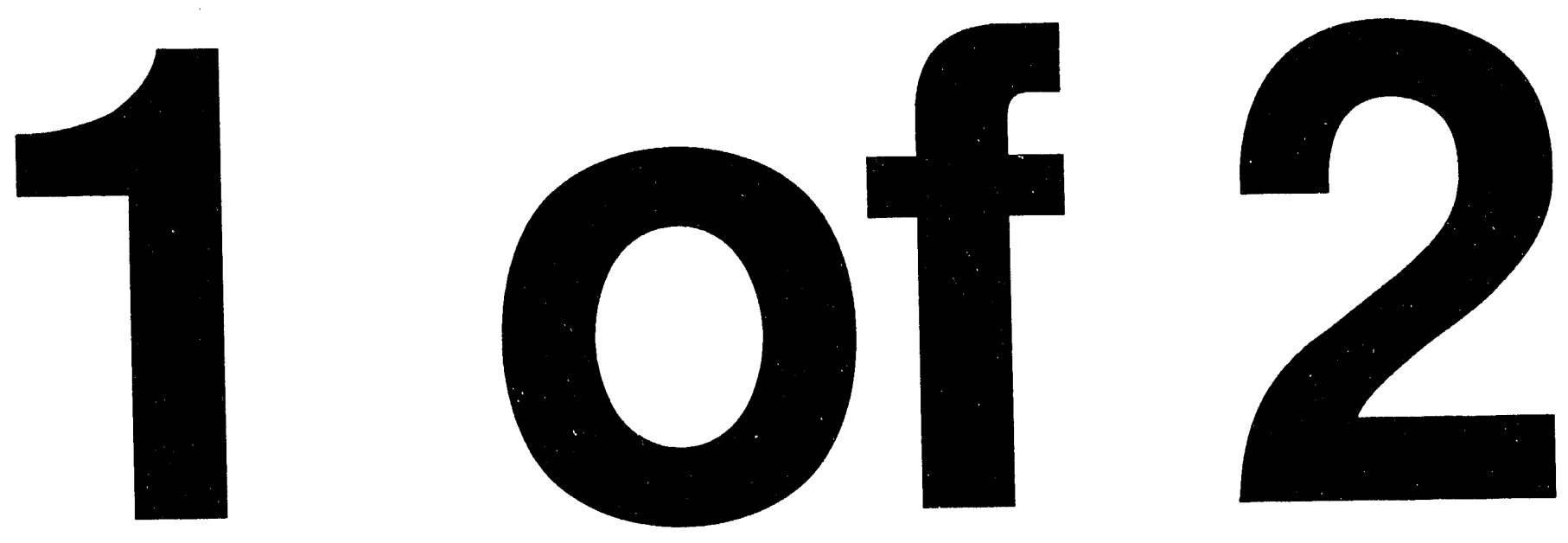
Distribution

Category UC-814

SAND92-2248

Unlimited Release

Printed December 1993

\title{
Estimations of the Extent of Migration of Surficially Applied Water for Various Surface Conditions Near the Potential Repository Perimeter
}

\author{
Steven R. Sobolik \\ YMP Performance Assessment Applications Department 6313 \\ Merton E. Fewell \\ WIPP Performance Assessment Department 6342 \\ Sandia National Laboratories \\ Albuquerque, New Mexico 87185
}

\begin{abstract}
The Yucca Mountain Site Characterization Project is studying Yucca Mountain in southwestern Nevada as a potential site for a high-level nuclear waste repository. Site characterization includes surface-based and underground testing. Analyses have been performed to support the design of site characterization activities so to have minimal impact on the ability of the site to isolate waste, and on tests performed as part of the characterization process. Two examples of site characterization activities are the construction of an Exploratory Studies Facility, which may include underground shafts, drifts, and ramps, and surface-based testing activities, which may require borehole drilling, excavation of test pits, and road watering for dust control. The information in this report pertains to two-dimensional numerical calculations modeling the movement of surficially applied water and the potential effects of that water on repository performance and underground experiments. This document contains information that has been used in preparing recommendations for two Yucca Mountain Site Characterization Project documents: Appendix I of the Exploratory Studies Facility Design Requirements document, and the Surface-Based Testing Field Requirements Document.
\end{abstract}

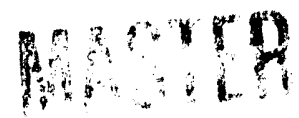


This report was prepared under Yucca Mountain Project WBS number 1.2.5.4.7. The information in this report was developed subject to QA controls in QAGR S12147A; the information is qualified and can be used for licensing.

\section{ACKNOWLEDGMENTS}

The authors would like to acknowledge the work of Jack Gauthier, Roger Eaton, and Larry Costin, who reviewed this document and the work contained herein, and Corinne Taylor, who provided valuable assistance in preparing the figures in this report. 


\section{CONTENTS}

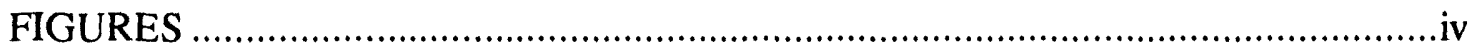

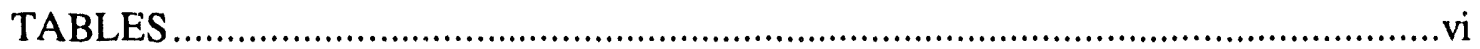

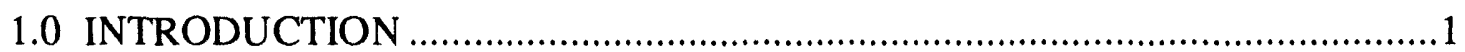

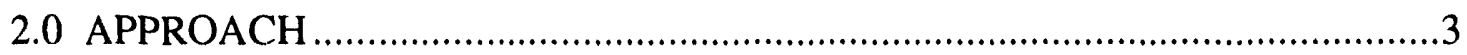

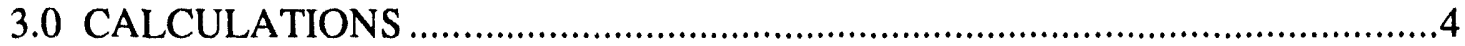

3.1 Case \#1: Road Watering Near the North Portal of the ESF ...........................5

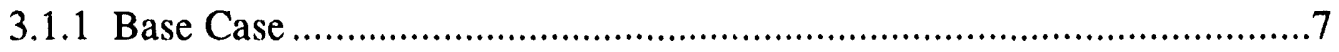

3.1.2 Sensitivity of Results to Grid Dimensions ........................................17

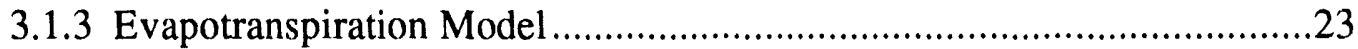

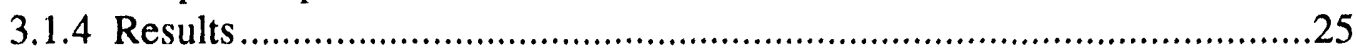

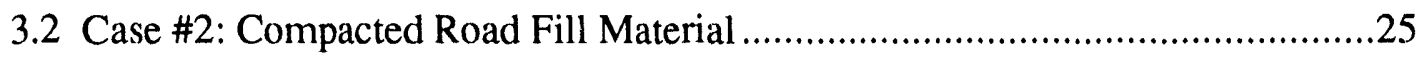

3.3 Case \#3: Water Movement in the Vicinity of UZ-16 ...................................41

3.4 Case \#4: Water Movement in the Vicinity of UZ-16 Considering the Expected Imbricate Faulting ............................................................................50

3.5 Case \#5: Water Movement Near USW H-5 Using a Horizontal Stratigraphic

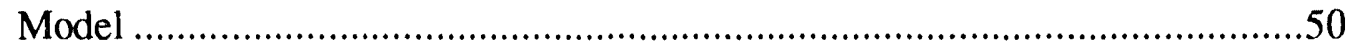

3.6 Case \#6: Water Movement Near USW H-5 Using a Stratigraphic Model with Natural Gradient ..............................................................................59

3.7 Case \#6U: Water Movement Near USW H-5 Considering the Natural Gradient and a Thin Alluvium Layer ...........................................................................68

4.0 IMPLEMENTATION OF THE RESULTS OF THIS ANALYSIS ....................73

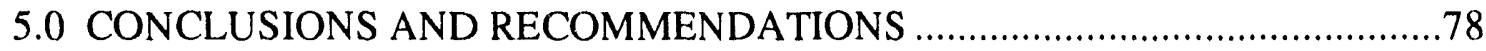

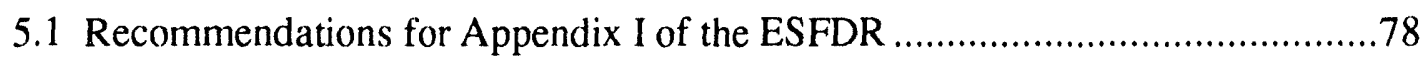

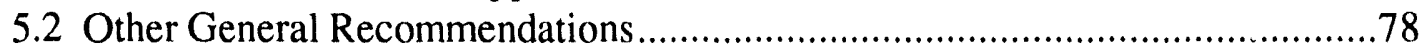

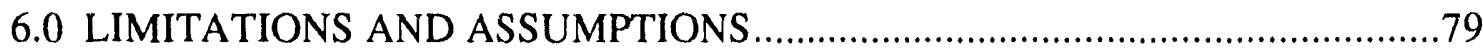

6.1 Surface Phenomena (Evapotranspiration and Surficial Water Application) .......79

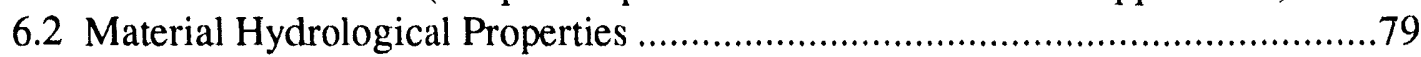

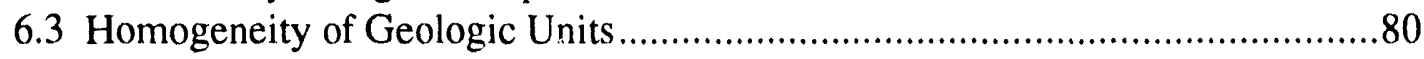

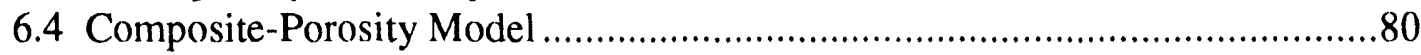

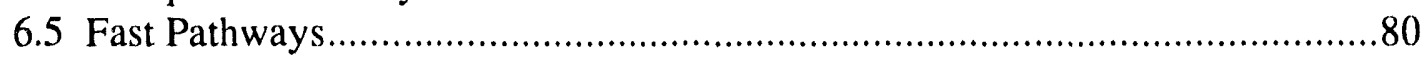

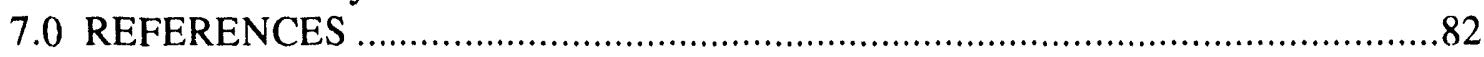

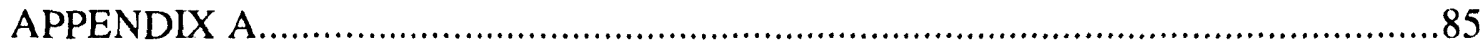

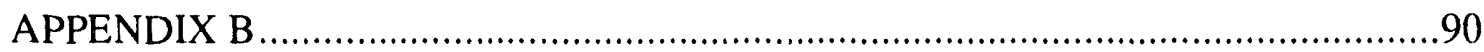

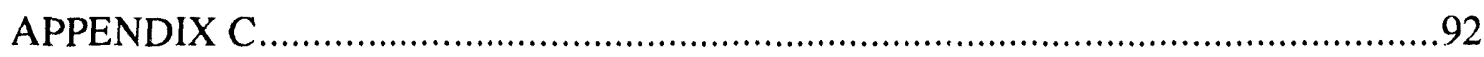




\section{FIGURES}

Figure 1: Selected Borehole Locations for Surficial Watering Analyses............................. 6

Figure 2: Case \#1 - Computational Grid .................................................................... 8

Figure 3: Case \#1 - Steady-State Saturation Profile ………......................................... 9

Figure 4: Case \#1 - Saturation After 1 Year of Surficial Watering..................................... 10

Figure 5: Case \#1 - Saturation After 5 Years of Surficial Watering .................................. 11

Figure 6: Case \#1 - Change in Saturation from Steady-State Conditions After 5 Years of

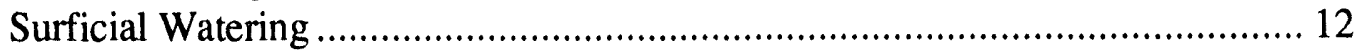

Figure 7: Case \#1 - Change in Saturation from Steady-State Conditions After 15 Years Resulting from 5 Years of Surficial Watering ................................................ 13

Figure 8: Case \#1 - Change in Saturation from Steady-State Conditions After 25 Years

Resulting from 5 Years of Surficial Watering ............................................... 14

Figure 9: Case \#1 - Change in Saturation from Steady-State Conditions After 10,000 Years Resulting from 5 Years of Surficial Watering ............................................ 15

Figure 10: Case \#1 - Saturation Profiles at 0, 5, and 10,000 Years................................. 16

Figure 11a: Case \#1 - Base Case Computational Grid (Alluvium, TCw, and PTn)............ 18

Figure 11b: Case \#1 - Finer Computational Grid (Alluvium, TCw, and PTn)................... 19

Figure 12: Case \#1 - Saturation After 1 Year of Surficial Watering (Finer Grid) ................ 20

Figure 13: Case \#1 - Saturation After 5 Years of Surficial Watering (Finer Grid) .............. 21

Figure 14: Case \#1 - Change in Saturation from Steady-State Conditions After 10,000 Years Resulting from 5 Years of Surficial Watering (Finer Grid) .............................. 22

Figure 15: Case \#1 - Saturation After 5 Years of Surficial Watering (with Evapotranspiration

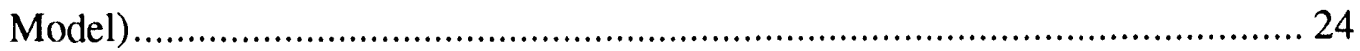

Figure 16: Case \#2 - Steady-State Saturation Profile in the Compacted Fill Road and the

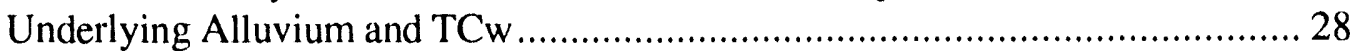

Figure 17: Case \#2 - Saturation After 1 Year of Surficial Watering.................................. 29

Figure 18: Case \#2 - Saturation After 2 Years of Surficial Watering ............................... 30

Figure 19: Case \#2 - Saturation After 5 Years of Surficial Watering ............................... 31

Figure 20: Case \#2 - Change in Saturation from Steady-State Conditions After 10,000 Years

Resulting from 5 Years of Surficial Watering ……………............................. 32

Figure 21: Case \#2 - Saturation After 8 Years of Surficial Watering ................................. 33

Figure 22: Case \#2 - Saturation After 10 Years of Surficial Watering .............................. 34

Figure 23: Case \#2 - Change in Saturation from Steady-State Conditions After 10,000 Years

Resulting from 10 Years of Surficial Watering............................................... 35

Figure 24: Case \#2 - Saturation After 15 Years of Surficial Watering .............................. 36

Figure 25: Case \#2 - Change in Saturation from Steady-State Conditions After 10,000 Years

Resulting from 15 Years of Surficial Watering................................................. 37

Figure 26: Case \#2 - Saturation Profiles at 0, 5, 10, and 15 Years of Surficial Watering... 38

Figure 27: Case \#2 - Saturation Profiles at 0 Years, and at 10,000 Years Resulting from 5-,

10-, and 15-Year Elevated Saturation Periods....

Figure 28: Results of Cases \#1 and \#2- Cumulative Net Flux Through the Wetted Surface 40

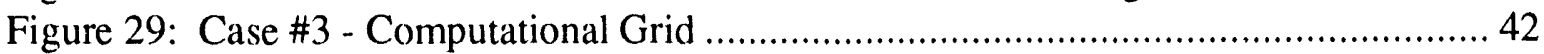

Figure 30: Case \#3 - Steady-State Saturation Profile ………………………….............. 43

Figure 31: Case \#3 - Saturation After 1 Year of Surficial Watering................................... 44 
Figure 32: Case \#3 - Saturation After 5 Years of Surficial Watering 45

Figure 33: Case \#3 - Change in Saturation from Steady-State Conditions After 5 Years of Surficial Watering....

Figure 34: Case \#3 - Change in Saturation from Steady-State Conditions After 10 Years

Resulting from 5 Years of Surficial Watering

Figure 35: Case \#3 - Change in Saturation from Steady-State Conditions After 15 Years Resulting from 5 Years of Surficial Watering 48

Figure 36: Case \#3 - Saturation Profiles for 0, 5, and 10,000 Years ................................ 49

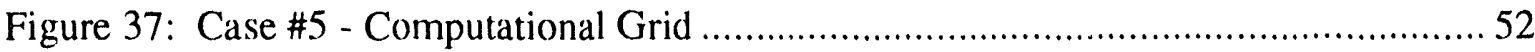

Figure 38: Case \#5 - Steady-State Saturation Profile …………....................................... 53

Figure 39: Case \#5 - Saturation After 5 Years of Surficial Watering ................................ 54

Figure 40: Case \#5 - Change in Saturation from Steady-State Conditions After 5 Years of

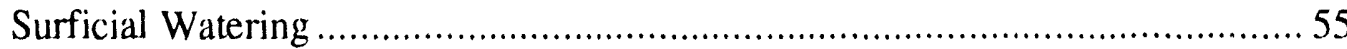

Figure 41: Case \#5 - Saturation After 15 Years of Surficial Watering .............................. 56

Figure 42: Case \#5 - Change in Saturation from Steady-State Conditions After 15 Years of

Surficial Watering

Figure 43: Case \#5 - Change in Saturation from Steady-State Conditions After 10,000 Years

Resulting from 15 Years of Surficial Watering.............................................. 58

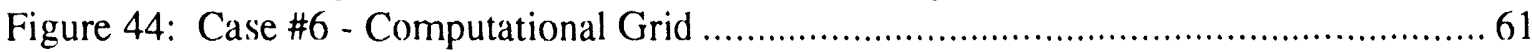

Figure 45: Case \#6 - Saturation After 5 Years of Surficial Watering ............................... 62

Figure 46: Case \#6 - Change in Saturation from Steady-State Conditions After 5 Years of Surficial Watering

Figure 47: Case \#6 - Change in Saturation from Steady-State Conditions After 15 Years of Surficial Watering

Figure 48: Case \#6 - Change in Saturation from Steady-State Conditions After 25 Years Resulting from 15 Years of Surficial Watering.

Figure 49: Case \#6 - Change in Saturation from Steady-State Conditions After 1000 Years

Resulting from 15 Years of Surficial Watering.

Figure 50: Case \#6 - Change in Saturation from Steady-State Conditions After 10,000 Years Resulting from 15 Years of Surficial Watering...

Figure 51: Case \#6U - Change in Saturation from Steady-State Conditions After 5 Years of

Surficial Watering

Figure 52: Case \#6U - Change in Saturation from Steady-State Conditions After 15 Years Resulting from 5 Years of Surficial Watering 70

Figure 53: Case \#6U - Change in Saturation from Steady-State Conditions After 100 Years Resulting from 5 Years of Surficial Watering 71

Figure 54: Case \#6U - Change in Saturation from Steady-State Conditions After 10,000 Years Resulting from 5 Years of Surficial Watering.

Figure 55: Comparison of NORIA-SP Calculations to Equation 1 Regarding Area Affected by Five Years of Surficial Watering..... 


\section{TABLES}

Table 1. Calculational Cases for ESF PA Analysis \#12 ................................................

Table 2: Evaluation of the Grid Sensitivity of Case \#1 Based on Infiltrated Water........17

Table 3: Compacted Fill Properties for Case \#2 ……................................................26

Table 4: Amount of Infiltrated Water for Selected Analytical Cases Evaluating Water Infiltration from Roads and Ponds............................................................74

Table 5: Estimations for Size of Wetted Area from NORIA-SP Calculations and from

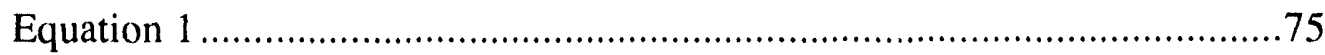

Table A.1. Definition of Input Parameters: Water Properties .....................................86

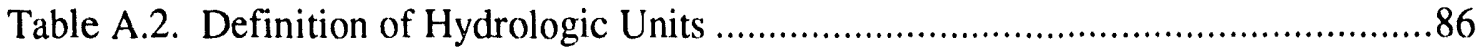

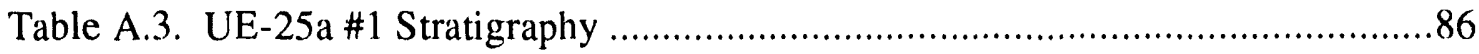

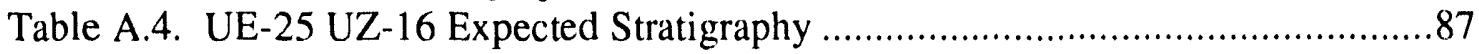

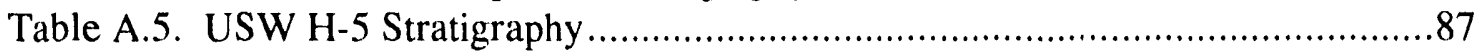

Table A.6. USW G-4 Stratigraphy and Hydrogeologic Properties ................................88

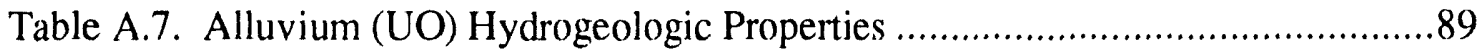

Table A.8. Compacted Road Fill Hydrogeologic Properties ..........................................89

Table B.1. Yucca Mountain Meteorological Data and the Resulting Monthly Evaporation Rate According to the Meyer Equation 89 


\subsection{INTRODUCTION}

The Yucca Mountain Site Characterization Project (YMP) is studying Yucca Mountain in southwestern Nevada as a potential site for a high-level nuclear waste repository. Site characterization includes underground and surface-based testing. Underground testing will be facilitated by the construction of an Exploratory Studies Facility (ESF). Surface-based testing will require boreholes, test pits, and other similar surface activities. Water will be used for compaction of fill material and for dust control during construction of roads and pads for the ESF and for surface-based testing. Water will also be used for such daily operations as dust control and sewage disposal; waste water could be stored in surface ponds. During these surface activities, there could also be accidental ipills. There is some potential for this water to affect repository performance, the proposed ex jeriments in the ESF, and surface-based testing locations, such as boreholes. Previous calculations have been performed to estimate the maximum amount of water that can infiltrate the surface above the potential repository during the proposed five-year ESF construction period without affecting repository performance (Fewell et al., 1992). These calculations are the basis for the current control for surface water application both inside and outside the perimeter of the potential repository. Current guidelines specify a maximum of 2 gallons per square yard per day averaged over any 6-month period for any pad or section of road. This restriction, which has been implemented in the Exploratory Studies Facility Design Requirements document (ESFDR) (DOE-YMP, 1992) and the Surface-Based Testing Field Requirements Document (SBTFRD) (DOE-YMP, 1993), is believed to be overly conservative in the limitations it places on field activities outside the repository perimeter. Additional analysis is required to determine whether a less conservative restriction is warranted. Also, the potential effects of road water on experiments in the ESF and in boreholes must be further evaluated. This report describes calculations performed to estimate the movement of surficially applied water at various locations and surface conditions both within and outside the perimeter of the potential repository in Yucca Mountain. The results of these calculations will be used to support ESF design and will be incorporated into the ESFDR and SBTFRD.

These calculations constituted one of several ESF analyses being performed in support of the ESFDR. The analysis described in this report is ESF Performance Assessment (PA) Analysis \#12, and it is intended to provide a basis for the evaluation of the movement of surficially applied water and the potential effects of that water on experiments and repository performance. The calculations and analyses performed for ESF PA Analysis \#12 were conducted as a quality-related activity in accordance with Sandia National Laboratories' (SNL's) implementation of the Yucca Mountain Project Quality Assurance Plan, and were controlled by Problem Definition Memo (PDM) 72-32 (PDM, 1992).

These calculations are based on available data and on the present conceptual understanding of the processes and mechanisms perceived to be active at Yucca Mountain. Because of limited knowledge of Yucca Mountain prior to site characterization, the hydrogeological conceptual model, other existing conceptual models of the physical processes, and the mathematical models used in these analyses are not validated. Recommendations based on the results of these analyses are intended to provide guidance for applying engineering judgment during the design, construction, and operation of the ESF and the conduct of surface-based activites. Therefore, 
they must provide relevant results to the architects and engineers who design the ESF. Refinement of the results is an ongoing and iterative process, which must complement site characterization. These calculations may be refined as better understanding evolves through site characterization and through additional analyses, which will address uncertainties and the sensitivity of the results to alternate conceptual models. 


\subsection{APPROACH}

The analyses defined for ESF PA Analysis \#12 estimate the movement of surficially applied water at various locations both within and outside the perimeter of the potential repository in Yucca Mountain and its potential effects on repository performance and on proposed experiments in the ESF, boreholes, and the near-surface. Seven separate cases were defined for analysis; these cases are listed in Table 1. One case was not evaluated due to a lack of information. The abbreviations used for the hydrologic units are from Ortiz et al. (1985), and are listed in Appendix A.

Table 1. Calculational Cases for ESF PA Analysis \#12

\begin{tabular}{|c|c|c|c|c|c|}
\hline \multirow{2}{*}{ Case } & \multirow[b]{2}{*}{ Stratigraphy. } & \multicolumn{3}{|c|}{ Wetted.Sufface Area (MRoad") } & \multirow{2}{*}{ Ilit or } \\
\hline & & Material: & Thickness & Width & \\
\hline 1 & UE-25a \#1 & Alluvium & $0.1 \mathrm{~m}$ & $12 \mathrm{~m}$ & Flat \\
\hline 2 & UE-25a \#1 & Road fill & $0.3 \mathrm{~m}$ & $12 \mathrm{~m}$ & Flat \\
\hline 3 & UE-25 UZ-16 & Alluvium & $0.1 \mathrm{~m}$ & $12 \mathrm{~m}$ & Flat \\
\hline 4 & UE-25 UZ-16 & $\begin{array}{l}\text { Case \#4 was } \\
\text { information in } \\
\text { substantially d }\end{array}$ & $\begin{array}{r}\text { ot perform } \\
\text { cating sub } \\
\text { ferent from }\end{array}$ & $\begin{array}{l}\text { ee to a } 1 \\
\text { ce imbri } \\
\text { assume }\end{array}$ & $\begin{array}{l}\text { viable } \\
\text { acturing } \\
\text { the other }\end{array}$ \\
\hline 5 & USW H-5 & $\mathrm{TCw}$ & $0.1 \mathrm{~m}$ & $12 \mathrm{~m}$ & Flat \\
\hline 6 & USW H-5 & $\mathrm{TCw}$ & $0.1 \mathrm{~m}$ & $12 \mathrm{~m}$ & Dip \\
\hline $6 \mathrm{U}$ & $\begin{array}{l}\text { USW H-5 } \\
\text { plus alluvium }\end{array}$ & $\begin{array}{c}\text { Alluvium (1 m } \\
\text { thick) }\end{array}$ & $0.1 \mathrm{~m}$ & $12 \mathrm{~m}$ & Dip \\
\hline
\end{tabular}

Calculations of water movement in layered, fractured, unsaturated porous media using the currently accepted mathematical models are complex and require sophisticated computer codes. The computer program NORIA-SP (Hopkins et al., 1991) was used to perform the calculations presented in this report. NORIA-SP numerically solves the two-dimensional Richards' equation for single-phase flow (liquid water) in porous media using the composite fracture/matrix porosity model (Peters and Klavetter, 1988). The van Genuchten model (van Genuchten, 1980) was used to describe the moisture characteristic curves for the matrix and fractures. Multi-phase and nonisothermal effects were assumed to be negligible. NORIA-SP has met the requirements of SNL's implementation of the YMP's criteria for software quality assurance. For these reasons, NORIA-SP was chosen to perform the two-dimensional calculations.

Because only the water that enters the mountain can affect potential repository performance and underground tests, these calculations were posed in terms of the amount of water that may infiltrate the ground through a continuously saturated road surface. For most of the calculations reported herein, the effects of evapotranspiration were disregarded. The physics associated with water transport at the surface is complicated and includes such unpredictable variables as the weather and surface topography. For these calculations, the rate of water infiltration into the surface beneath the road surface is a function of the in situ saturation and material properties of the road surface and underlying layers, and it is assumed that water entering the surface cannot leave the mountain. 


\subsection{CALCUlations}

The problem is conceptualized as follows. Prior to the addition of water, the mountain is at the steady-state saturation conditions that correspond to a uniform infiltration of $0.01 \mathrm{~mm} / \mathrm{yr}$ through the surface. ${ }^{1}$ These steady-state solutions were used as the initial conditions for the transient calculations. At "time zero," a portion of the surface (wetted surface, or "road") was suddenly saturated, and continuously maintained at saturation for a period of time (elevated saturation period), while water continued to infiltrate the remainder of the surface at $0.01 \mathrm{~mm} / \mathrm{yr}$. A saturated boundary condition was imposed at the water table. After the elevated saturation period, water infiltrated the entire surface at $0.01 \mathrm{~mm} / \mathrm{yr}$. For selected calculations, an alternate model for the flux rate through the non-wetted surface was used; this flux was either evaporative or infiltrating, depending on the saturation level at the surface. (This evapotranspiration model will be described in Section 3.2.) The movement of the surficial water was followed for 10,000 years. This conceptual model assumes no surficial ponding of water.

Calculations based on the conceptual model described above were made at three locations: near the North Ramp Portal of the ESF (Cases \#1 and \#2), near the location of borehole UE-25 UZ-16 (Cases \#3 and \#4), and "up-dip" of the repository perimeter (Cases \#5, \#6, and \#6U). The sensitivity of surficial water movement to road fill material was investigated at the North Portal location by performing calculations using two different road materials, the naturally-occurring alluvium (Case \#1) and a compacted road fill (Case \#2). The North Portal is approximately 1430 $m$ from the potential repository block at its closest point. The effects of highly fractured zones were to be investigated at the UZ-16 location by performing calculations with two sets of hydrogeological properties: one with the same properties as Cases \#1 and \#2 (Case \#3); and the other with hydrogeological properties indicative of the highly fractured imbricate fault zone (Case \#4). Calculations for Case \#4 were not conducted because the only viable information regarding the expected magnitude of fracturing at the UZ-16 site indicated little if any difference from the model used for Case \#3. The sensitivity to stratigraphic dip was investigated at the "up-dip" location (borehole USW H-5) by performing calculations without (Case \#5) and with (Case \#6) stratigraphic dip. Additional calculations to evaluate the effects of dip on water flow through a thin layer of alluvium were performed at the USW H-5 location (Case \#6U). For Cases \#2, \#5, and \#6, calculations were made for three different elevated saturation periods of 5,10 , and 15 years, which correspond to possible periods of surface activities at Yucca Mountain. Calculations for Cases \#1, \#3, and \#6U were performed only for a 5-year elevated saturation period. Figure 1 shows the three borehole locations with respect to the potential repository block.

The borehole UE-25a \#1 was selected as a model for the North Portal area. The stratigraphies for boreholes UE-25a \#1 and USW H-5 were obtained from the Reference Information Base (RIB), Version 2.002. The stratigraphy that was used for the UZ-16 location is the anticipated

\footnotetext{
1 Montazer and Wilson (1984) estimate the percolation rate through the tuff matrix in the Topopah Spring unit to be between $10^{-4} 1010^{-7} \mathrm{~mm} / \mathrm{yr}$. Weeks and Wilson (1984) estimate the rate to be between 0.003 and $0.2 \mathrm{~mm} / \mathrm{yr}$. Based on these estimates, $0.01 \mathrm{~mm} / \mathrm{yr}$ was chosen as a representative value for the steady-state surface infiltration. Also, saturation values obtained by the steady-state calculations at $0.01 \mathrm{~mm} / \mathrm{yr}$ are within the range of saturation values that presently reside in the Reference Information Base (RIB), with the exception of those reported for the nonwelded Paintbrush Tuff layer PTn. (See the explanation in Section 6.2.)
} 
stratigraphy for UE-25 UZ-16 (Hayes and Chaney, 1991), for which construction began in early 1992. These stratigraphies are listed in Appendix A. The material hydrogeologic properties that were used are the current best available data from USW G-4 and USW GU-3 (Peters et al., 1984). The selected values for the hydrogeological properties for both the USW G-4/GU-3 units and the alluvium layer are listed in Appendix A. Values for the compacted road fill material are also listed in Appendix A; the rationale for selecting those values is discussed in Section 3.2.

The problem domain for each case was two-dimensional and cartesian, extending from the water table to the surface. For Cases \#1-\#5, the stratigraphic units were horizontal and parallel; for Case \#6, the stratigraphic units were parallel and dipped approximately $4^{\circ}$ to the east. The width of a typical road $(12 \mathrm{~m}$ ) was used for the wetted surface area. Symmetry allowed a no-flow boundary to be placed at the road centerline for Cases \#1-\#5. The other vertical boundary was also defined as a no-flow boundary and placed at a distance far enough away such that road water was not expected to migrate there during the 10,000-year period. (The selection of the distance between vertical boundaries did not always have the desired effect, as discussed in later sections.) For Cases \#6 and \#6U, the locations of the vertical no-flow boundaries were placed such that no flow reached either vertical boundary during the elevated saturation period.

\subsection{Case \#l: Road Watering Near the North Portal of the ESF}

The calculations for Case \#1 are used here as the base case to which all other cases will be compared. This case models the underground movement of surficial water applied to a road consisting of virgin alluvium, on a section of road near the North Portal. Three sets of calculations were performed using the Case \#1 scenario: a base case for which the in situ infiltration rate of $0.01 \mathrm{~mm} / \mathrm{yr}$ was used as the steady-state infiltration rate; a repeat of the base case using a finer grid to test for sensitivity of the results to the choice of grid; and a repeat of the base case utilizing a simple evapotranspiration model for elevated saturation levels at the surface. 


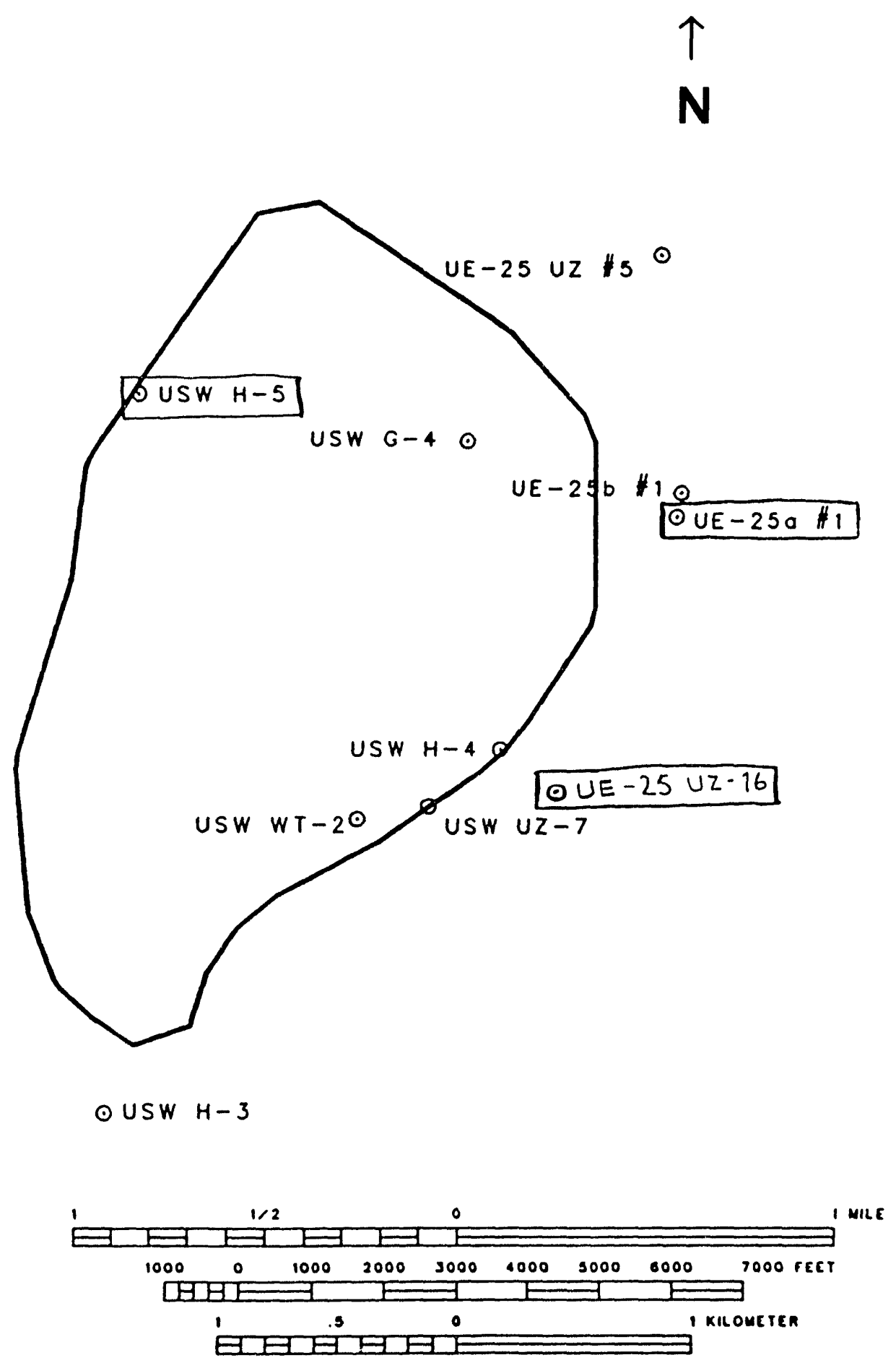

Figure 1: Selected Borehole Locations for Surficial Watering Analyses 


\subsubsection{Base Case}

The calculations for Case \#1 employed a computational grid containing 30 columns and 38 rows of elements, for a total of 1140 finite elements (see Figure 2). The computational domain was $90 \mathrm{~m}$ wide, and the centerline of the road formed the vertical boundary at the origin (left side). The bottom boundary was the water table level at the UE-25a \#1 location, and the ground surface formed the top boundary. The alluvium was divided into two parts. The top $0.1 \mathrm{~m}$ of the alluvium formed the top row of elements and was designated as the row that contained the road. This road layer was made to be thin to minimize the artificial addition of water (i.e., resulting from the numerical modeling of the problem) to the alluvium as a result of forcing the top row of nodal points in the road section to $100 \%$ saturation. Figure 3 illustrates the in situ saturation levels throughout the stratigraphy resulting from the steady-state infiltration rate of $0.01 \mathrm{~mm} / \mathrm{yr}$. (Please refer to Section 6.2 for a discussion of the assumptions used regarding material properties and the resulting in situ conditions calculated for PTn.)

After the application of the surficial boundary condition, the alluvium directly beneath the road became saturated after about 1 year (see Figure 4). ${ }^{2}$ Approximately $9.6 \mathrm{~m}$ of water had infiltrated through the road surface by this time. ${ }^{3}$ As only about $2 \mathrm{~m}$ of water would be required to saturate the alluvium directly beneath the road, much of this water has spread laterally in the alluvium. Because of the relatively low conductivity of the underlying Tiva Canyon welded (TCW) unit, movement of water in the alluvium along the alluvium-TCw interface is much more significant than infiltration of the water into the TCw and underlying stratigraphy. At 5 years, the calculations indicated that approximately $24 \mathrm{~m}$ of water had infiltrated the alluvium through the wetted alluvium road, and water had moved to nearly $54 \mathrm{~m}$ away from the edge of the road. Figure 5 shows the saturation in the top three hydrologic units after 5 years, and Figure 6 shows the change in saturation from in situ conditions (i.e., $\Delta$ sat) after 5 years. At this point, road watering was discontinued and the steady-state infiltration of $0.01 \mathrm{~mm} / \mathrm{yr}$ was restored to the entire surface. The plots of $\Delta$ sat in Figures 7 and 8 show that water was nearing the edge of the computational domain after 15 years of activity, and had reached the edge after 25 years. Therefore, lateral water movement was artificially restrained, and the vertical movement was exaggerated, for the remainder of the calculations as a result of the no-flow vertical boundary conditions. A plot of $\Delta$ sat throughout the stratigraphy at 10,000 years (Figure 9) indicates that a significant change in saturation comes no closer than about $100 \mathrm{~m}$ from the Topopah Spring welded unit (TSw2) in which the potential repository may be located. A comparison of the saturation along the road centerline for in situ conditions and at 5 and 10,000 years (Figure 10) shows no change in in situ conditions below $200 \mathrm{~m}$ above the water table, or about $30 \mathrm{~m}$ above the elevation of the closest portion of the proposed repository horizon.

\footnotetext{
2 The "road" that has been superimposed on Figure 4 and many other figures in this paper is intended to show the width of the road in the context of the problem. The road may look raised in the figures, but in the analyses the top of the road was always at grade with the surrounding surface.

3 The amount of infiltrated water is reported throughout this paper in the unit of meters. For example, $9.6 \mathrm{~m}$ of water means that 9.6 cubic meters infiltrates through each square meter of road surface.
} 


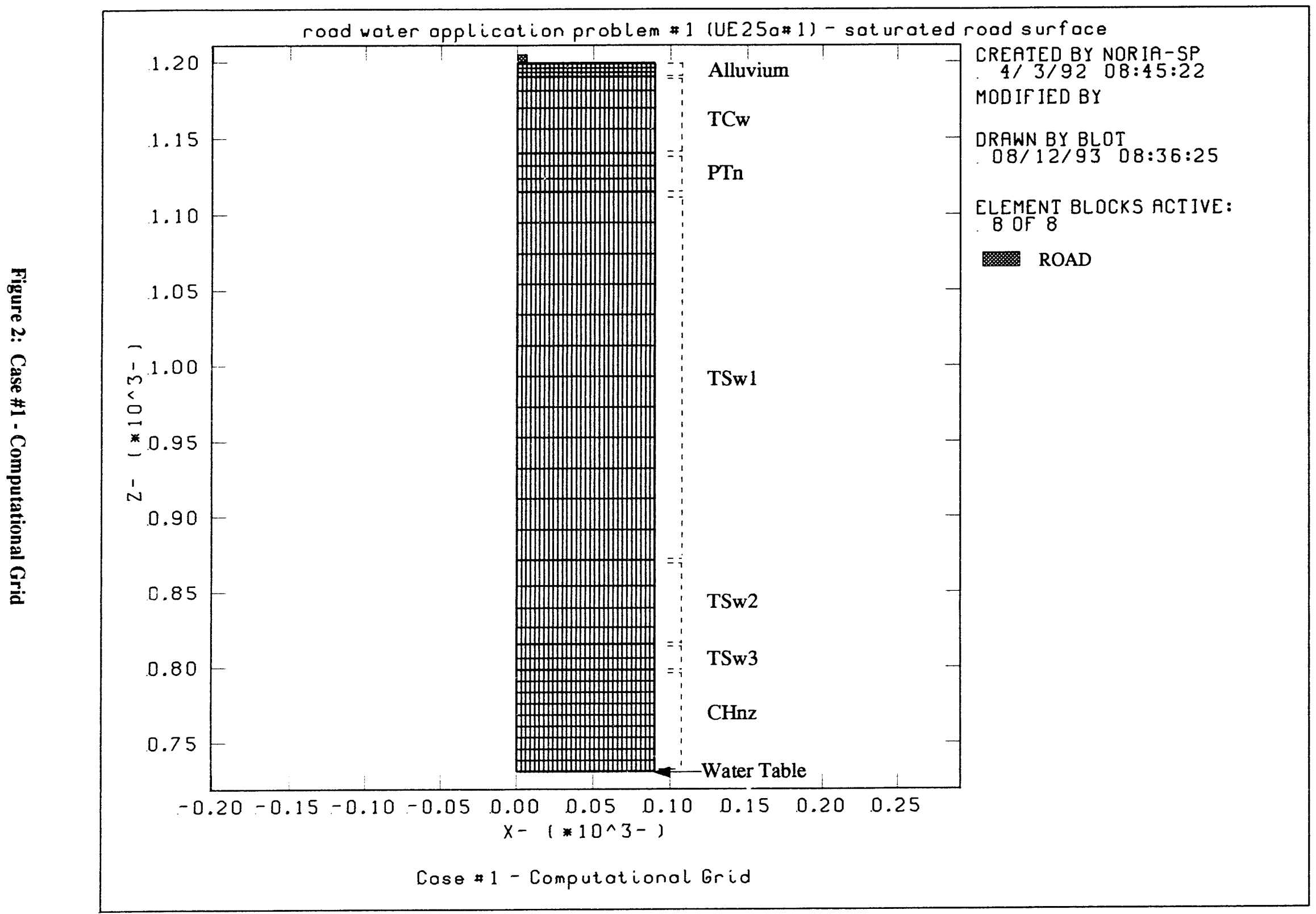




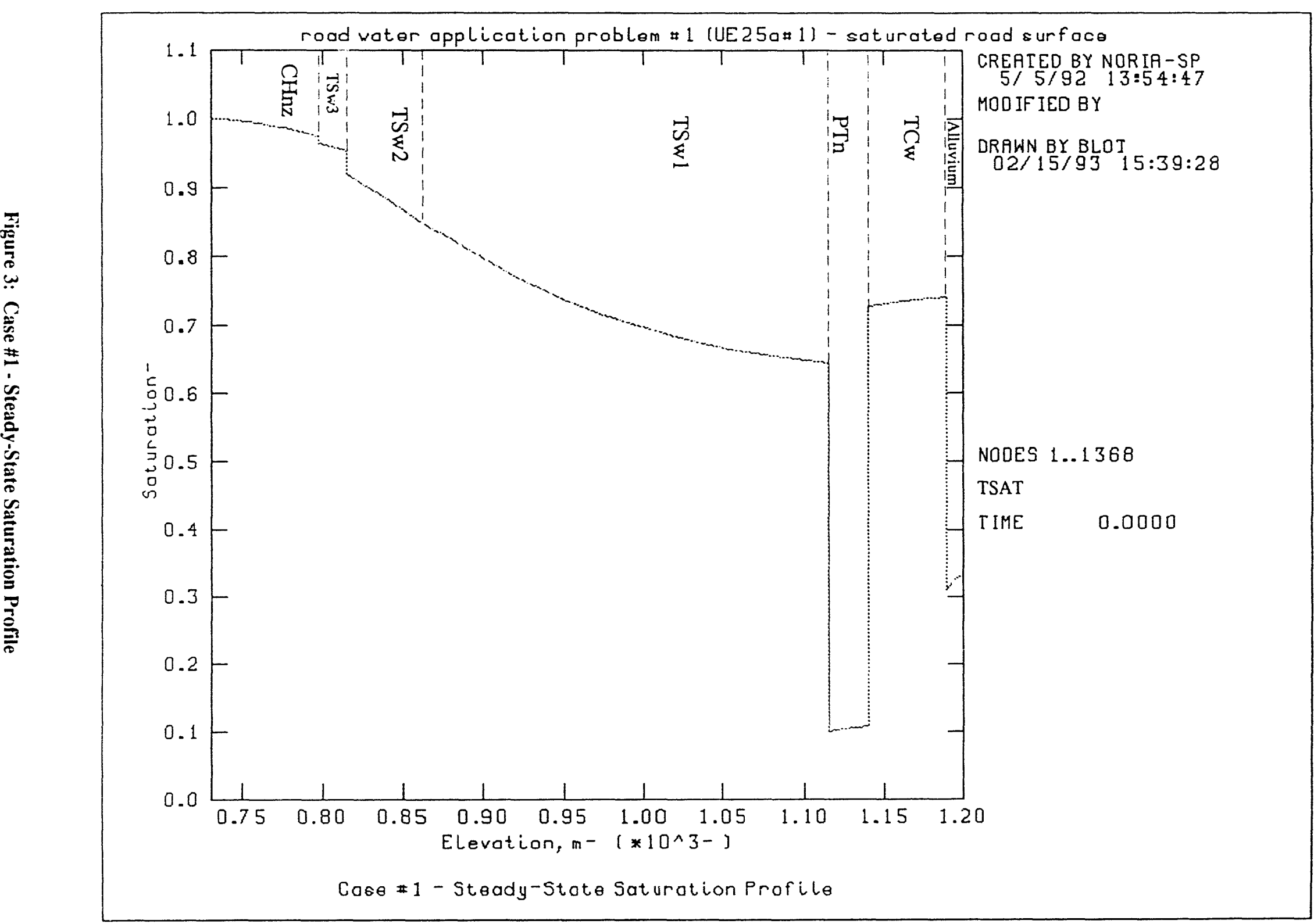




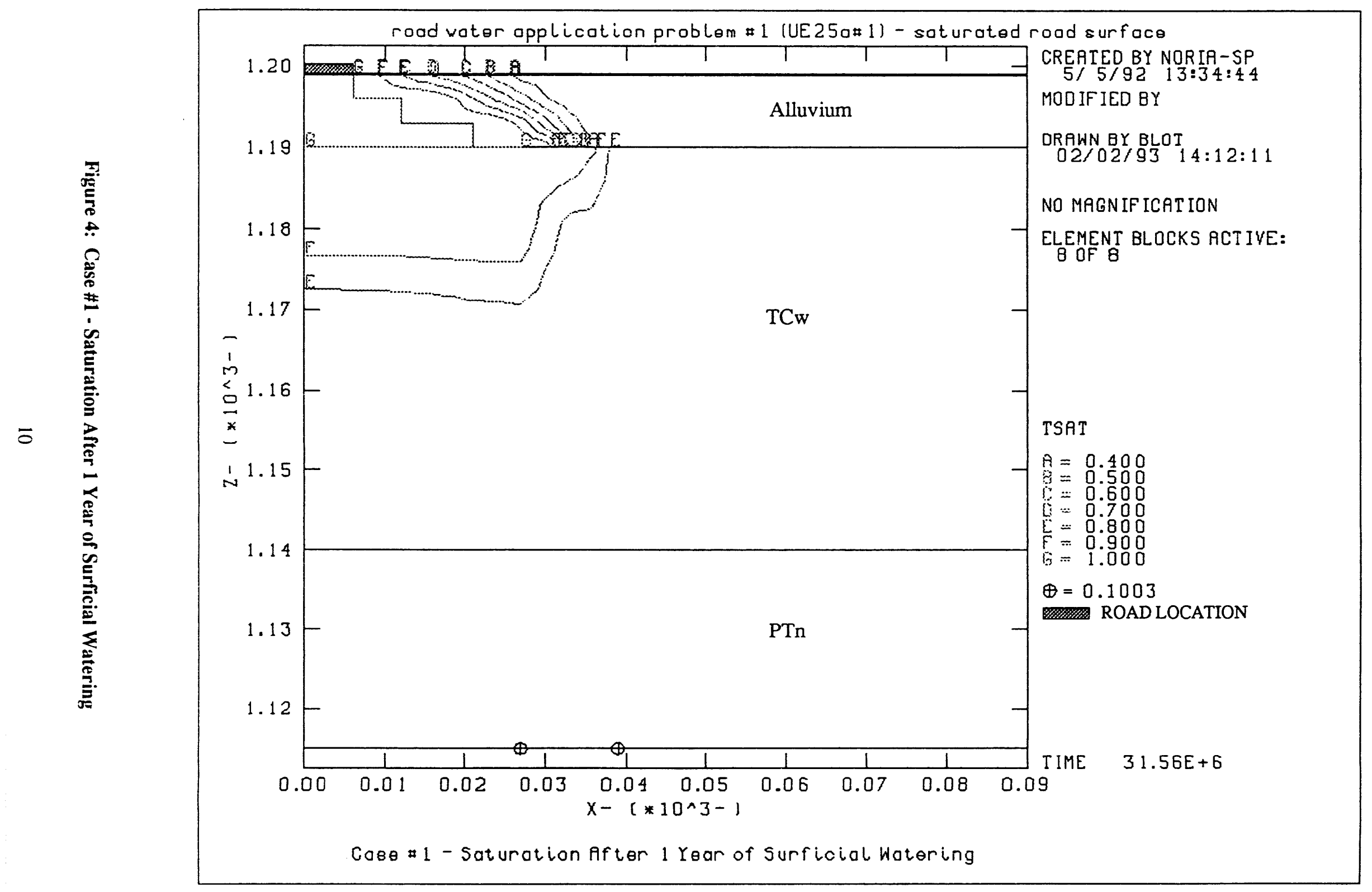




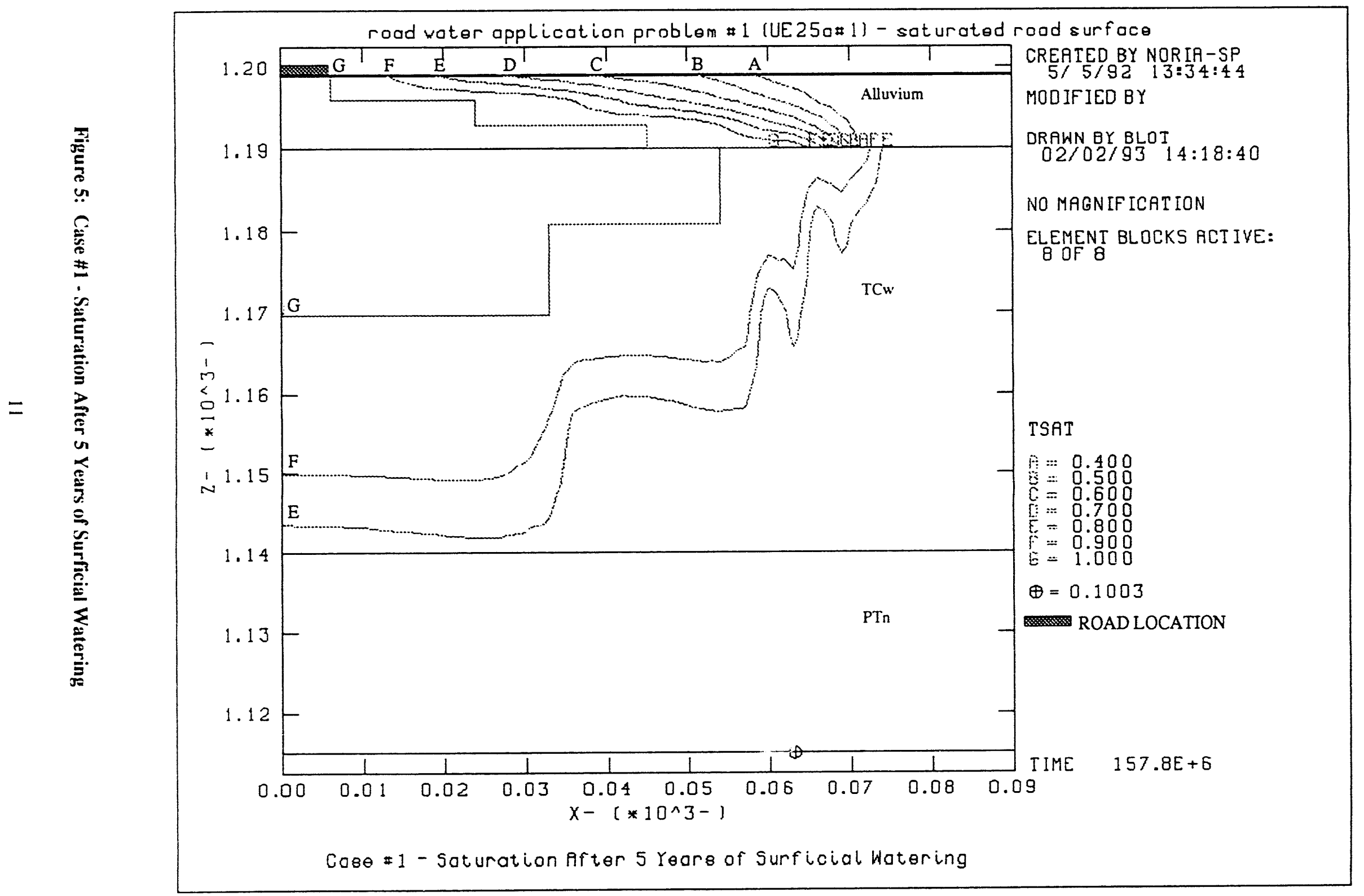




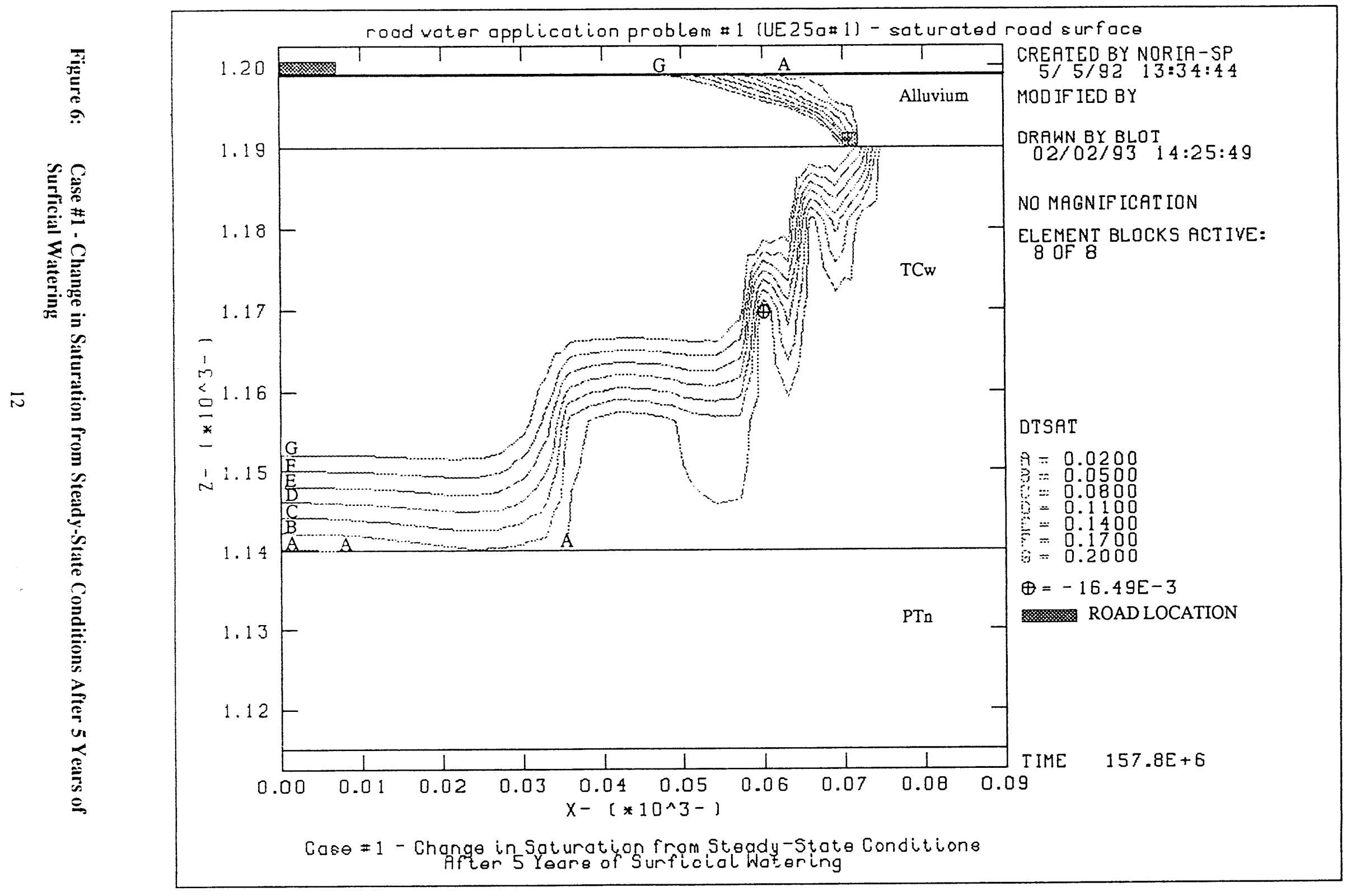




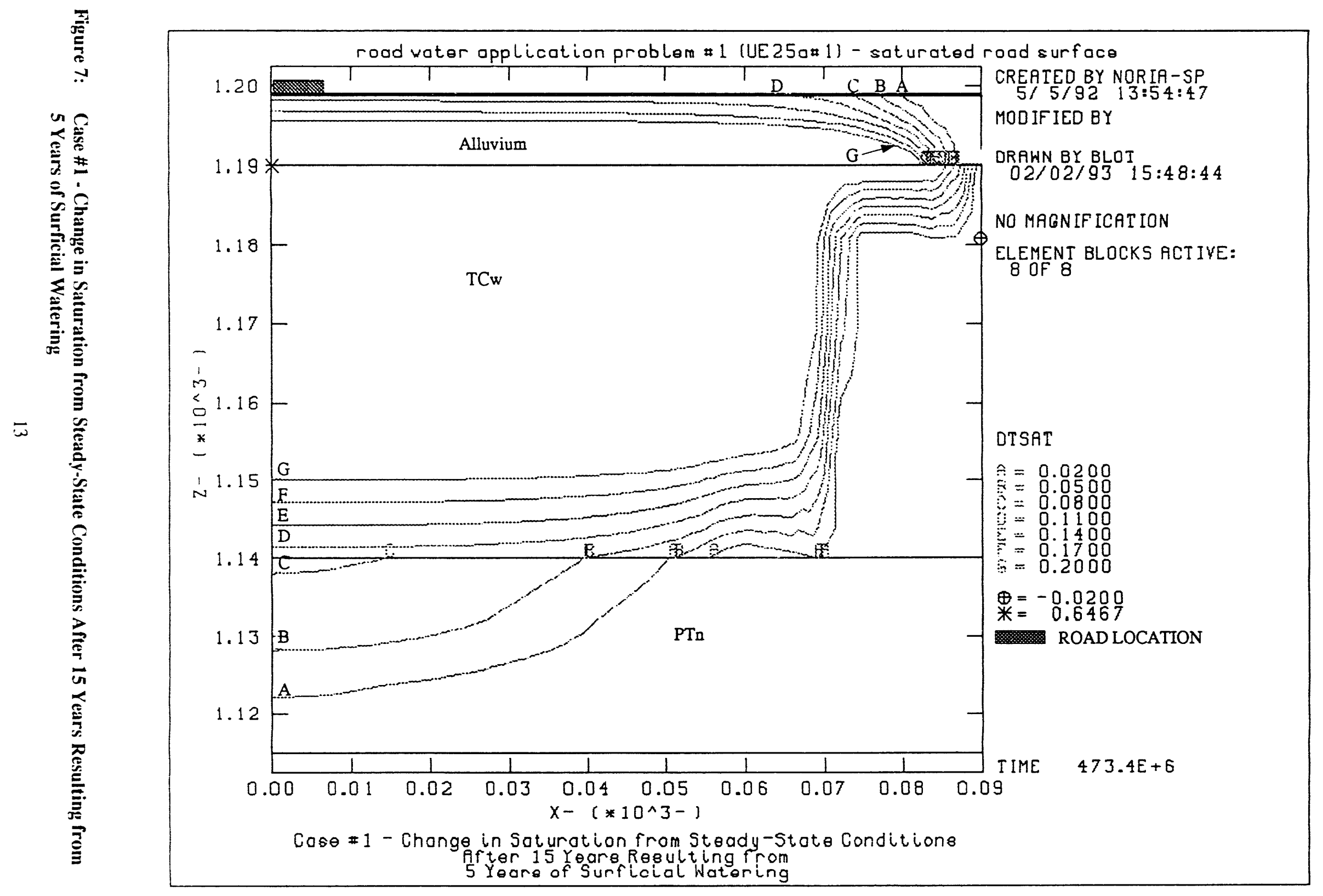




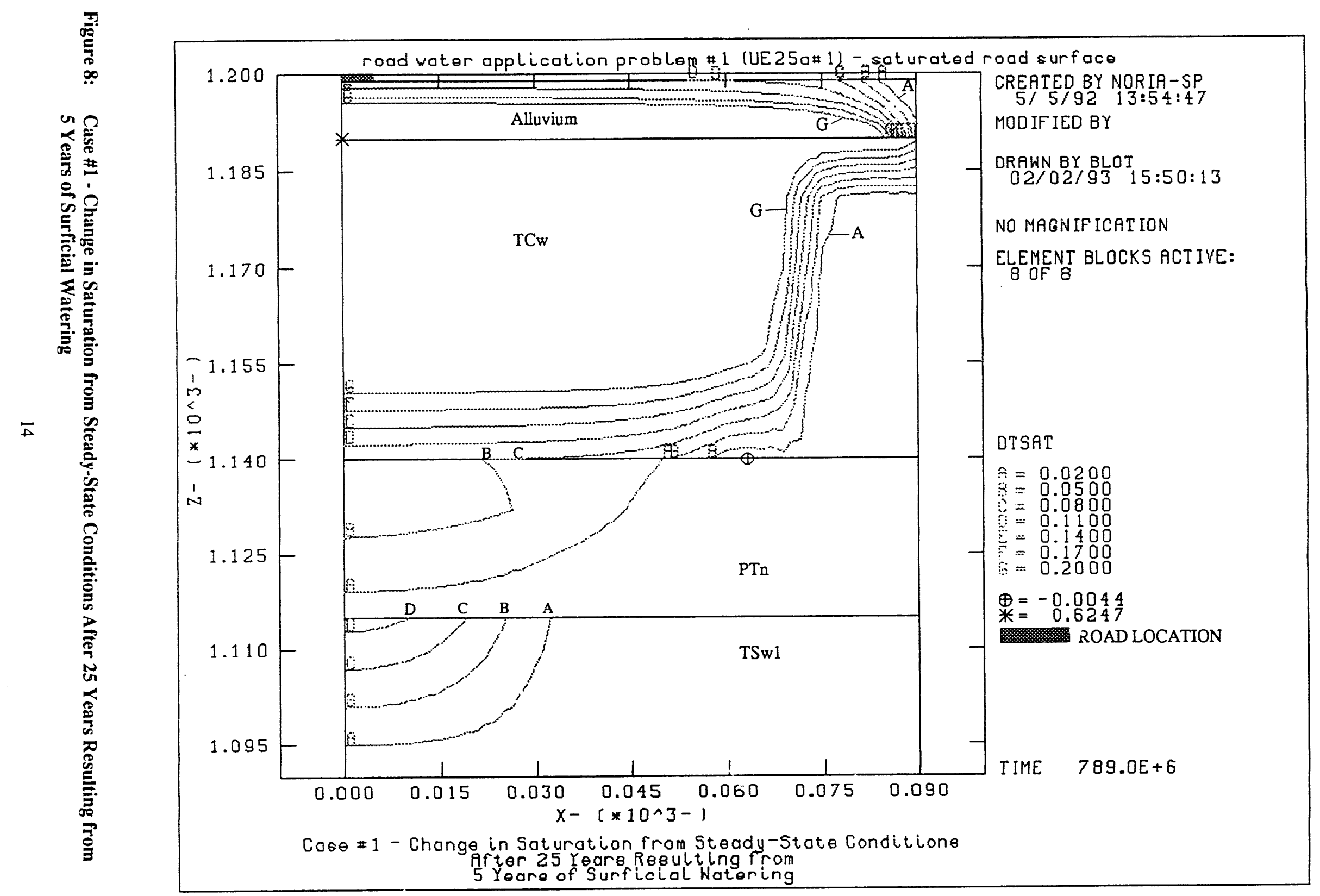




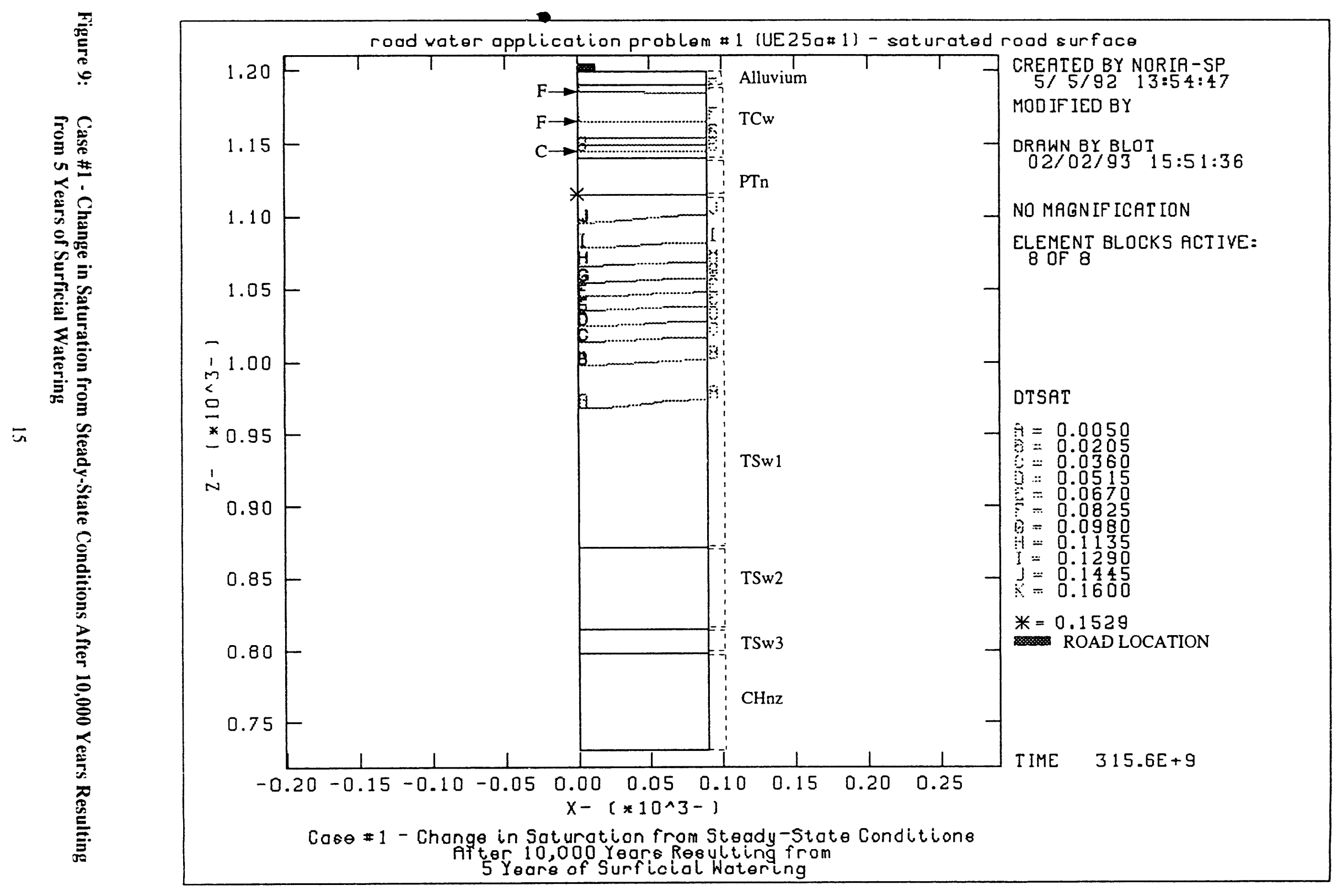




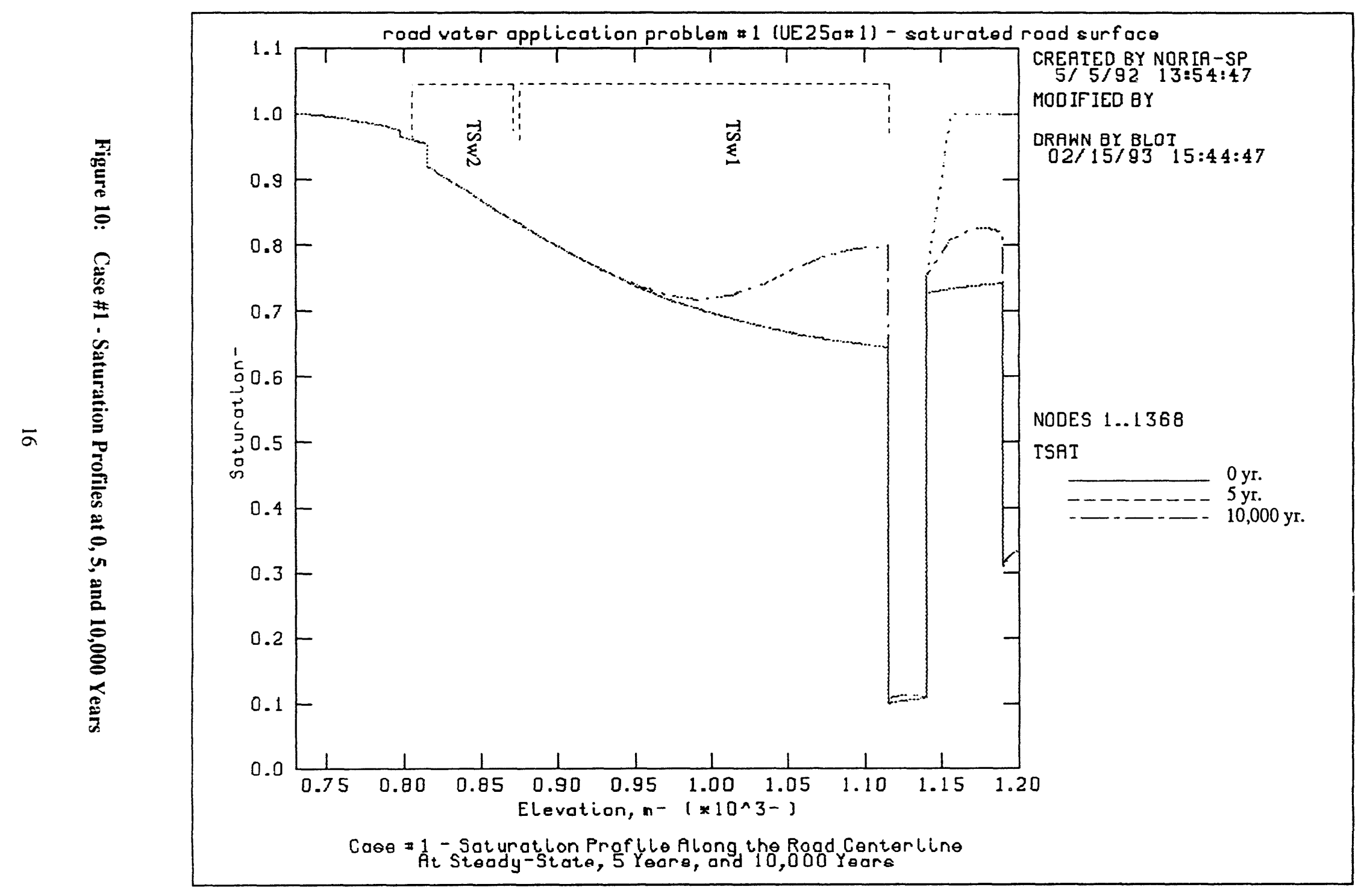




\subsubsection{Sensitivity of Results to Grid Dimensions}

An appropriate step in any numerical analysis is to estimate the discretization error inherent to the calculations. Such an estimate has been determined for Case \#1 by re-running the base case with a different calculational mesh employing closer node spacing and reduced aspect ratios. The results are compared graphically and by computing predictions of infiltration amounts at various times.

The new grid remained at a width of $90 \mathrm{~m}$, but the number of evenly-spaced elemental columns was increased from 30 to 45 , making each element $2 \mathrm{~m}$ wide. Two rows of elements were added to each of the top three stratigraphic layers under the road; this gave the alluvium 5 rows, TCw 6 rows, and the nonwelded Paintbrush Tuff unit (PTn) 5 rows in the new grid. Figure 11a shows the original grid in the top three stratigraphic layers for Case \#1, and Figure 11b shows the same for the finer grid. The rows in the affected units had the same row-to-row thickness ratio within each unit as in the original grid. The aspect ratios (i.e., width-to-height ratios of individual finite element cells) in alluvium, TCw, and PTn remained approximately the same $(1.01,0.18-0.33$, and 0.36 for alluvium, TCw, and PTn, respectively, in the original grid versus $1.12,0.16-0.41$, and 0.4 respectively, in the finer grid). The thin road layer was maintained at one row of elements; therefore, the increase in the number of columns reduced the aspect ratio in this layer from 30 to 20. To minimize the run time by limiting the number of elements, the Calico Hills unit and the bottommost Topopah Spring unit were eliminated from the grid. The boundary condition for the bottom boundary was a constant pressure equal to the steady-state pressure at the TSw2-TSw3 interface calculated for the original grid.

As in the original calculations for Case \#1, the road surface was maintained at $100 \%$ saturation for 5 years, after which the steady-state infiltration rate of $0.01 \mathrm{~mm} / \mathrm{yr}$ was applied over the entire surface. Figures 12 and 13 are plots of saturation at 1 and 5 years using the finer grid, and Figure 14 is a plot of $\Delta$ sat after 10,000 years. Examination of the graphs and comparison to Figures 4,5 , and 9, reveal some minor differences, especially in the $\mathrm{TCw}$ unit during the first five years, but the results from the finer grid support the results from the original grid. Table 2 compares the amount of infiltrated water at various times up to 5 years for both grids; the results of the two calculations are essentially the same. The same conclusions that were drawn from the calculations with the original grid can be drawn from those with the finer grid.

Table 2: Evaluation of the Grid Sensitivity of Case \#1 Based on Infiltrated Water

\begin{tabular}{|l|c|c|}
\hline Time (yr) & $\begin{array}{c}\text { Amount of Infiltrated Water, } \\
\text { Original Grid }(\mathrm{m})\end{array}$ & $\begin{array}{c}\text { Amount of Infiltrated Water, } \\
\text { Finer Grid }(\mathrm{m})\end{array}$ \\
\hline 1 & 9.58 & 9.38 \\
\hline 2 & 14.05 & 13.87 \\
\hline 3 & 17.63 & 17.65 \\
\hline 4 & 20.97 & 20.98 \\
\hline 5 & 23.80 & 24.00 \\
\hline
\end{tabular}




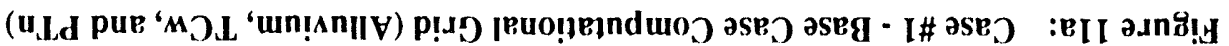

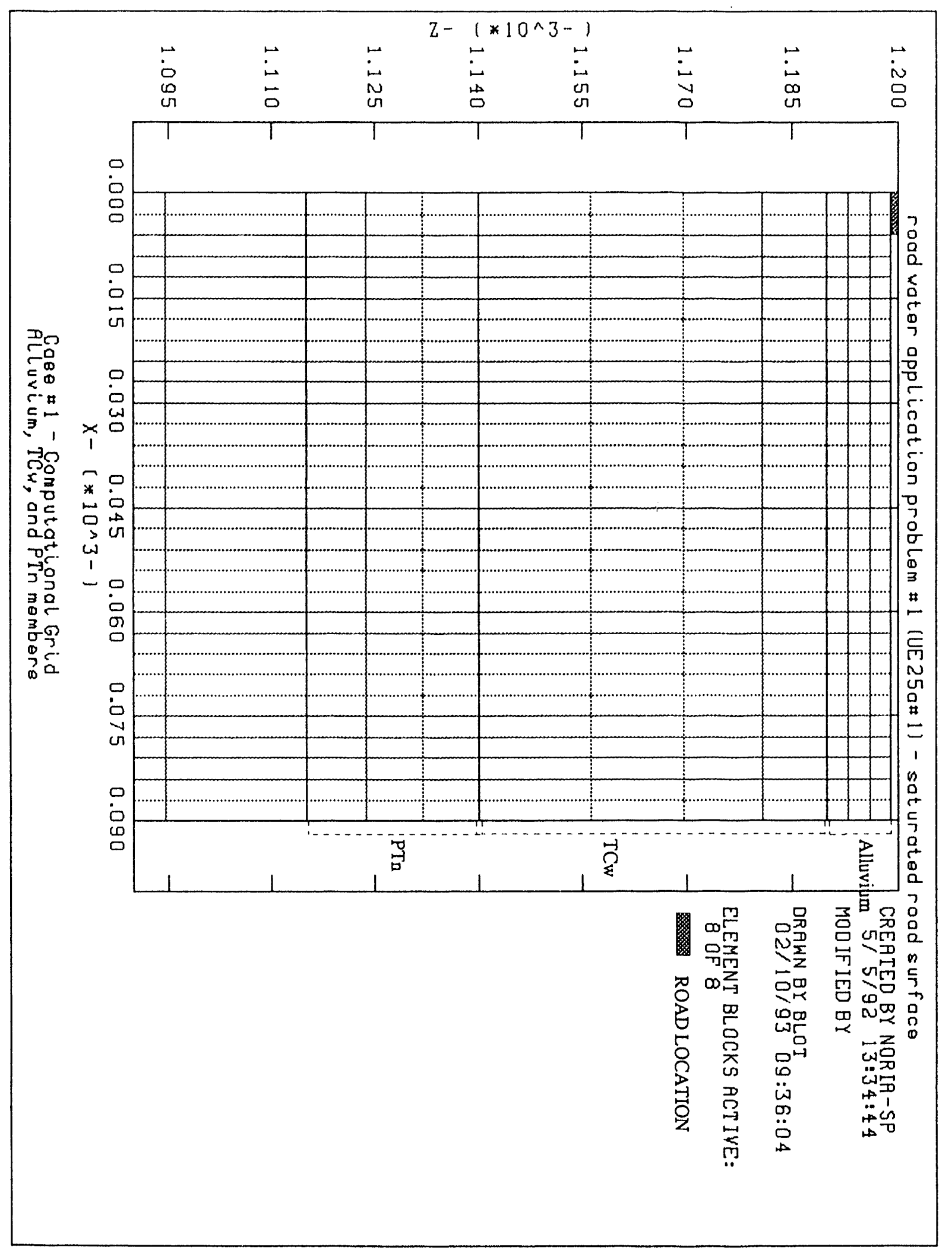




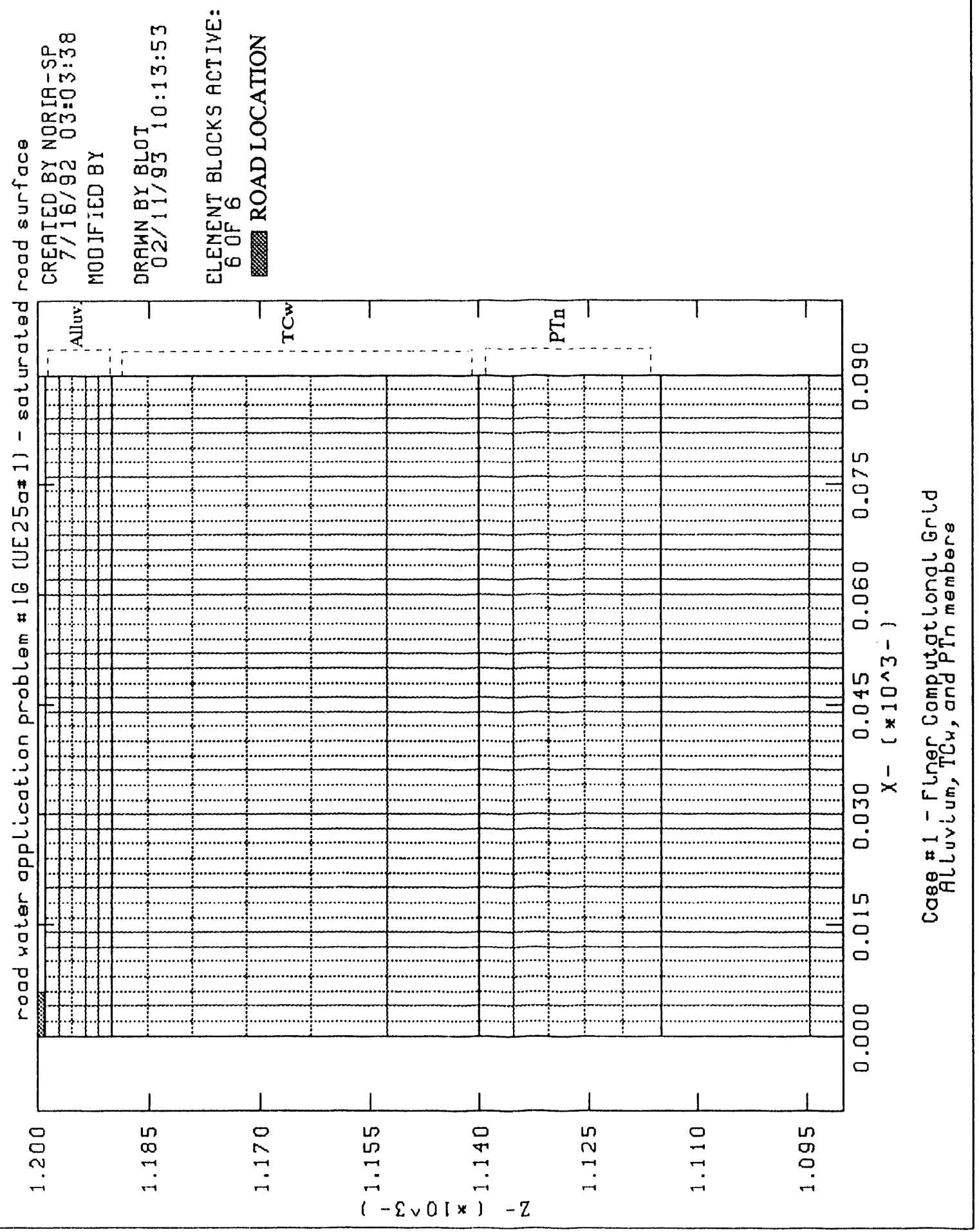

Figure 11b: Case \#1 - Finer Computational (Grid (Alluvium, $\mathrm{TCw}$, and PTn) 


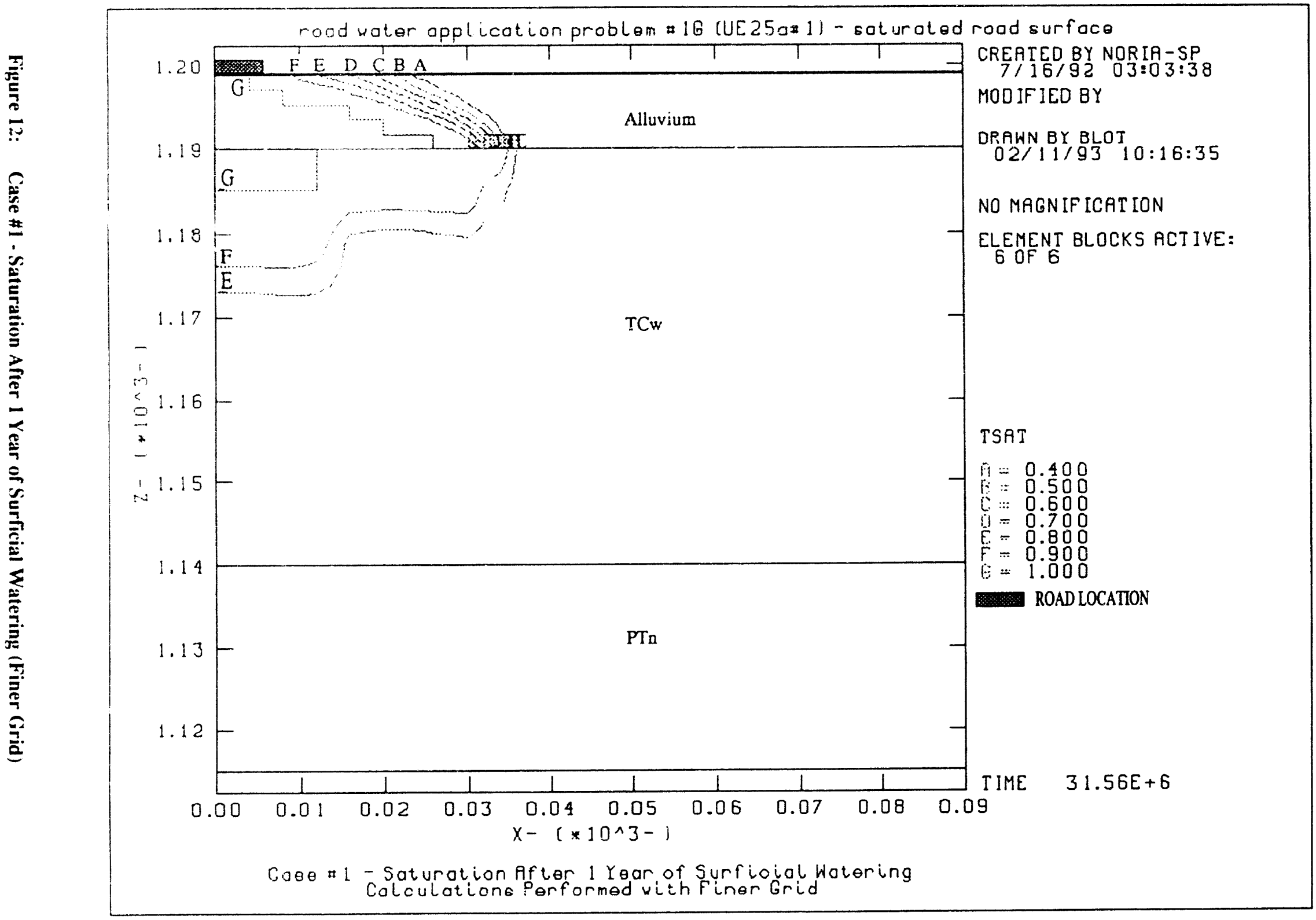




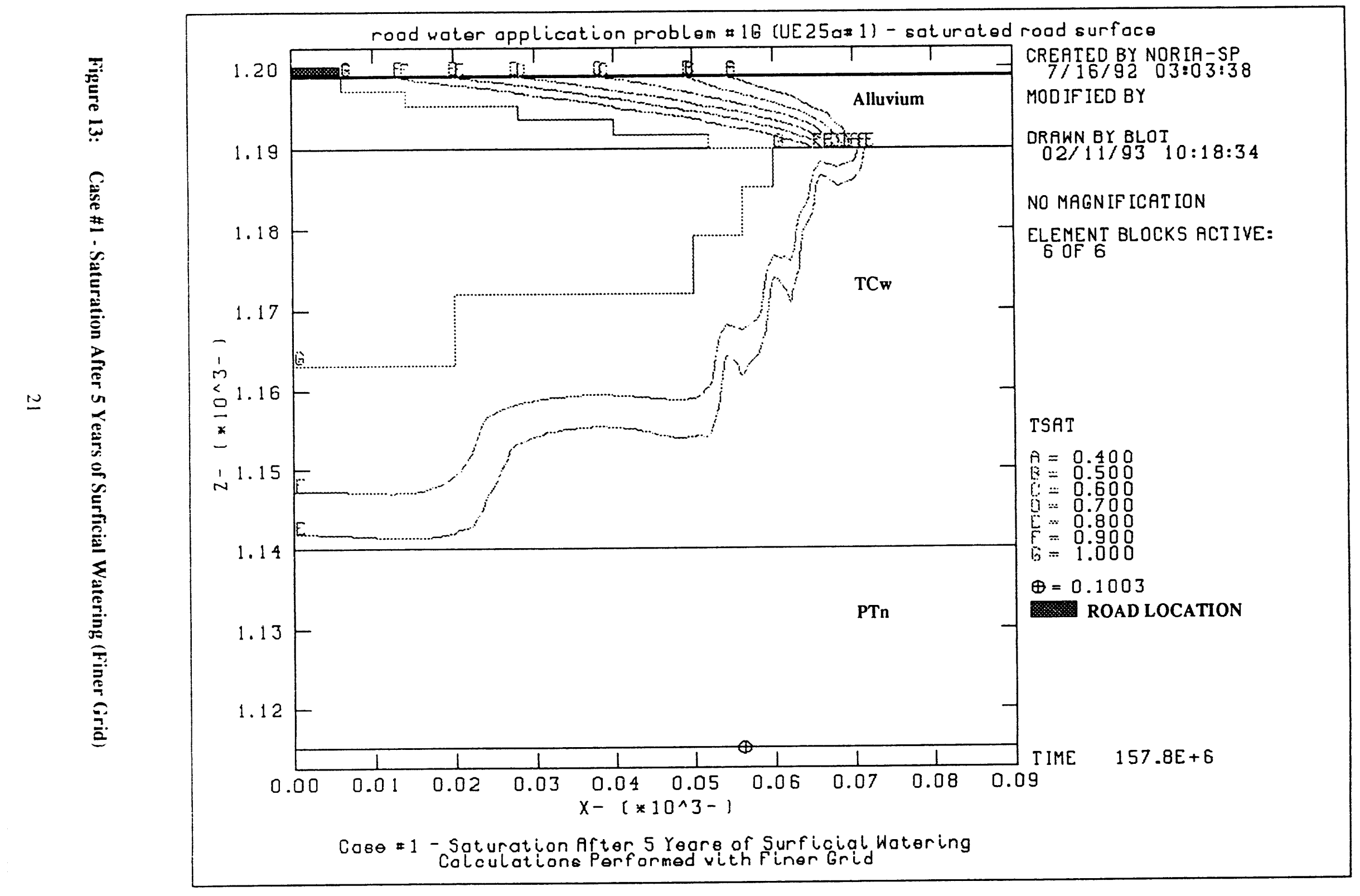




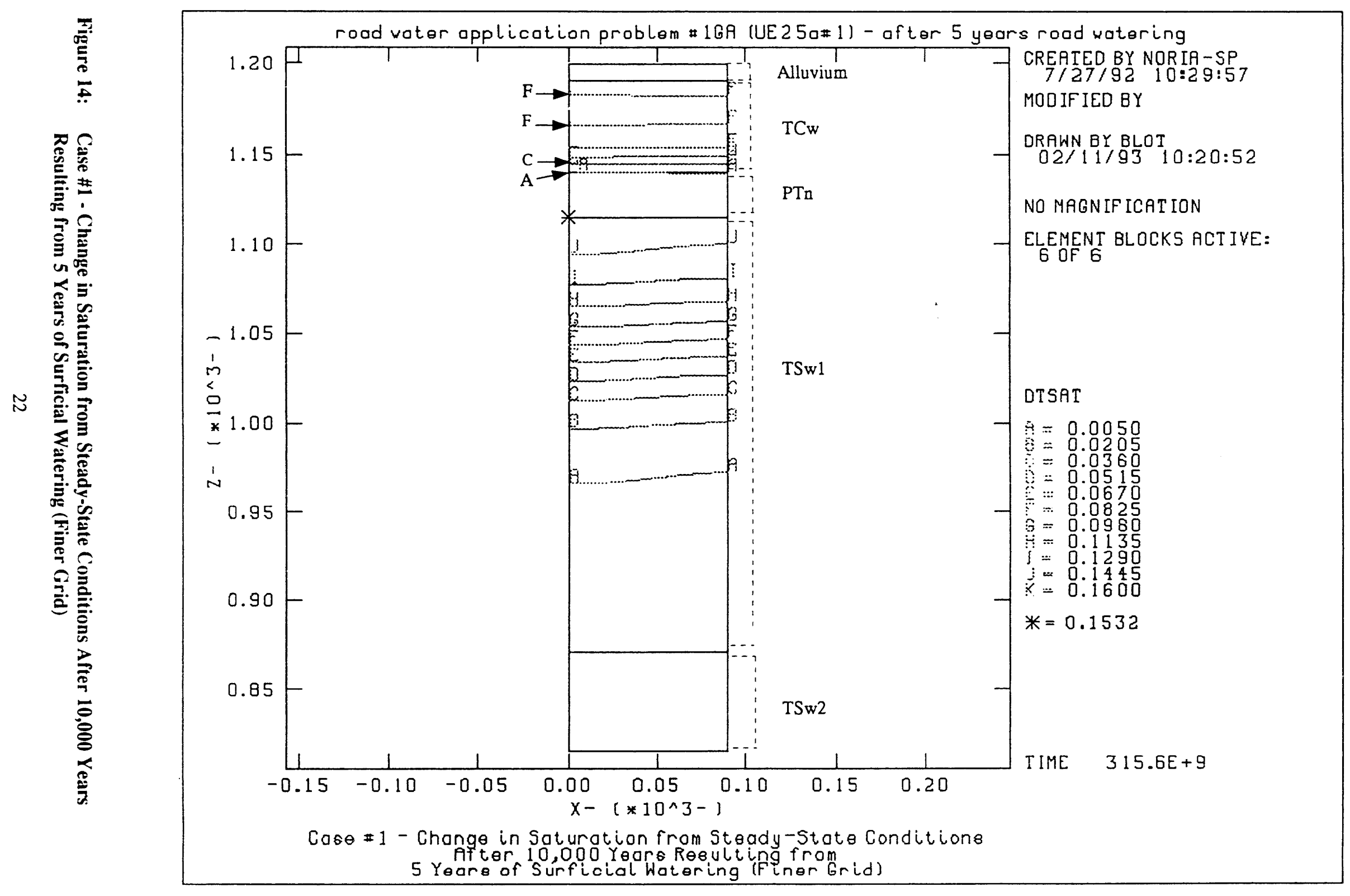




\subsubsection{Evapotranspiration Model}

The original boundary conditions imposed on the wetted and non-wetted surfaces for Case \#1 did not allow any evaporation of the additional water from the alluvial surface. The assumption of no evaporation may be extremely conservative, and when implemented in the calculations for Case \#1, might result in overly restrictive requirements regarding the standoff distances between experiments in boreholes and access roads. An initial attempt was made to impose an evapotranspiration (ET) model on the non-wetted surface based on the local level of saturation. The model is described more extensively in Appendix B. In essence, the flux of water from the non-wetted surface is a function of the local saturation level. If the local saturation $s=s_{\text {in }}$ situ the local flux was assumed to equal the steady-state infiltration. If lateral migration of road water has created a locally saturated condition at the surface $(s=100 \%)$, then the flux was set equal to the evaporation rate for a small shallow pond (see Appendix B). For saturation $s_{\text {in situ }} \leq s \leq 100 \%$, an asymptotic function between these two values is used.

This ET model was implemented for the Case \# 1 calculations starting with the original solution at 6 months. Figure 15 plots saturation in the top three stratigraphic layers after 5 years. The only visible differences with the original calculations (see Figure 5) are in the extent of the region of $100 \%$ saturation. The ET model slows down the lateral movement of surficial water, but not very much. This might indicate that for surficial water applications for which the wetted area is maintained at constant saturation for a long period of time (such as a waste water pond), ignoring ET is not extremely conservative in predicting migration. The amount of water that infiltrated the road surface after 5 years for the ET model calculations was $23.40 \mathrm{~m}$, compared with $23.80 \mathrm{~m}$ for the original calculations. Therefore, the application of this ET model had little effect on the infiltration and dispersion of surficial water. Because this ET model is unvalidated, and because the results obtained by using this model were effectively unchanged from the base case, these results were not used to derive conclusions regarding the use of surficial water near Yucca Mountain. 


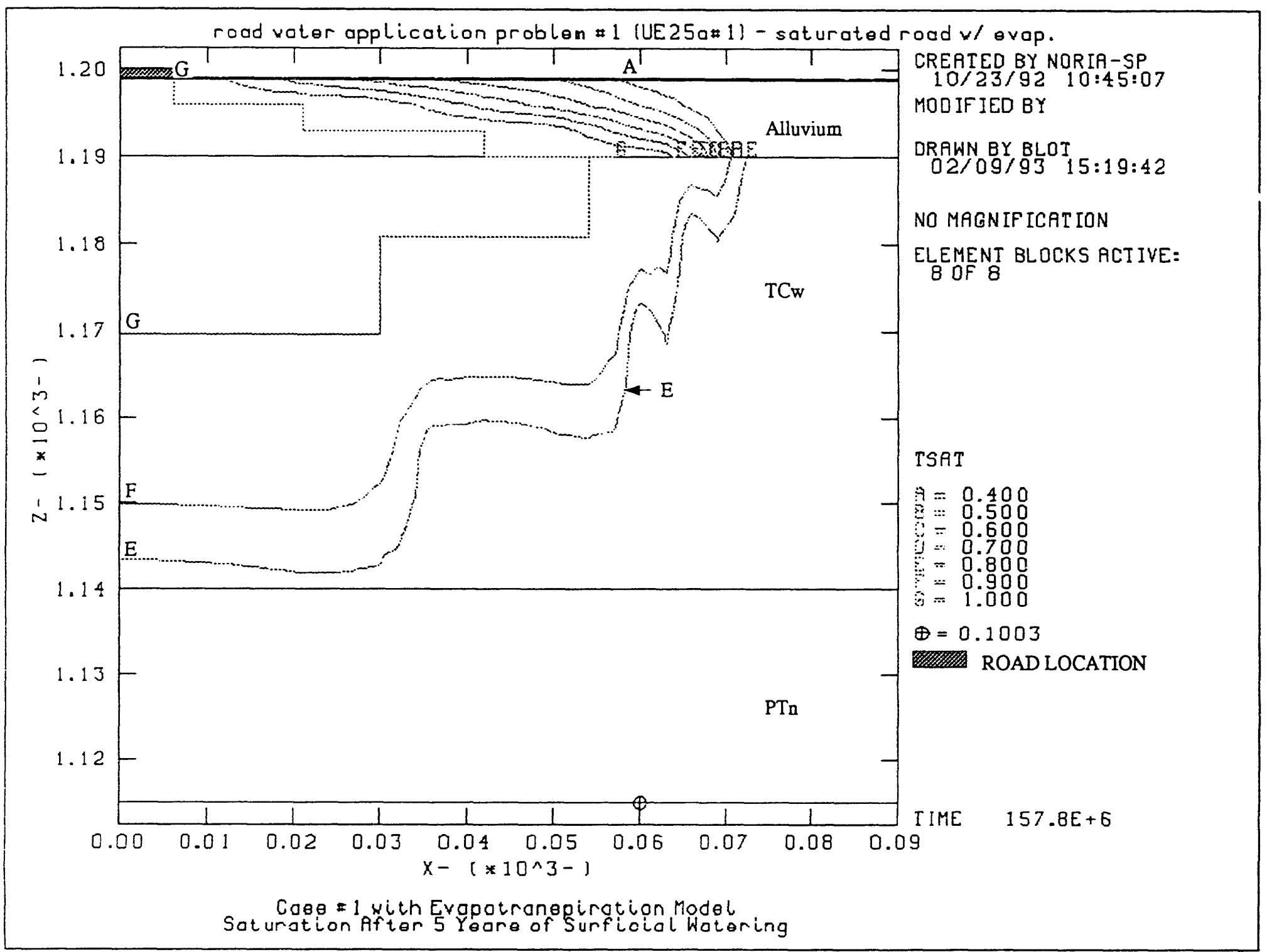




\subsubsection{Results}

An analysis of the results of Case \#1 indicates that there is little or no likelihood that surficial water applied near the North Portal will impact potential repository performance, but tests conducted in the near-surface and in neighboring boreholes may be affected. These results show that the alluvium soaks up a lot of water and distributes it over a large area. Therefore, it may be important to construct a road such that its watering requirements are small and its permeability to water is relatively low; this premise forms the basis of the investigation described in Section 3.2 of the effects of compacted road material on the migration of surface water.

It is worthwhile to comment on a phenomenon that is particularly apparent in Figures 5 and 13. These solutions at 5 years show a flow pattern that could be misinterpreted as fingering, which is a process characterized by flow along fractures. These "fingers" are actually a numerical idiosyncrasy of NORIA-SP that has been observed in this and other analyses, particularly in the $\mathrm{TCw}$ unit. As the water front moves through the $\mathrm{TCw}$, the large pressure gradient near the leading edge induces a quasi-sinusoidal pulse ahead of the front. This pulse is in the direction of the pressure gradient; i.e., for the horizontal movement of water, the gradient occurs primarily in the horizontal direction $(\partial \mathrm{P} / \partial \mathrm{x})$, and the quasi-sinusoidal pressure pulse is a function of only the horizontal spatial variable $|\mathrm{P}(\mathrm{x})|$. The sinusoidal nature of the pulse is apparent in the leading edge of the front as well. Calculations from the NORIA-SP results of the total change in water volume at various times after the five-year road watering scenario indicate that this numerical oscillation has no significant effect on the mass balance of the simulated system. As can be seen in Figures 5 and 13, the effect diminishes with increasingly finer meshes. There is no analytical siginficance to this numerical phenomenon, and this small oscillation does not affect the conclusions drawn from the results of these calculations.

\subsection{Case \#2: Compacted Road Fill Material}

While much data exists regarding the hydrogeological properties of a number of soils and clays, very little information exists regarding compacted fill materials. The authors obtained information about compacted roads that are built in locales such as southwestern Nevada. ${ }^{4}$ Roads built of compacted fill are generally 6-in. to 12-in.-thick plates of soil and clay material at $95 \%$ compaction. All the material in the fill must pass through a 1 -in. screen before compaction. After compaction, the road material typically has a moisture content of $10 \%$ to $12 \%$.

An effective compacted road fill material must be less permeable to water than alluvium and other similar soils. Therefore, it was decided to select a value for the saturated hydraulic conductivity of the compacted fill equal to $5.0 \times 10^{-8} \mathrm{~m} / \mathrm{s}$. This value is one order of magnitude less than that used for alluvium, and nearly four orders greater than that used for TC' $w$. A value of $15 \%$ was chosen for the porosity; this value is slightly higher than the moisture content, which implies that

\footnotetext{
4 The information regarding typical fill materials, compaction me thods, and moisture content of compacted roads was obtained in a personal communication with Joe Catorti of Reynolds Electrical and Engincering (omprany (REEC O), Las Vequas. Nevadda, on May 19, 1992. He later sent us some additional information on compacted fill that supported the information he gave us previously. Records of this information can be found in the analysis fite for PIDM 72-32 in the SNL YMP Local Records Center.
} 
the fill is not entirely saturated when compacted. The values for residual saturation and for the van Genuchten curve-fitting parameters were those for silty clay (Carsel and Parrish, 1988), whose composition is much like the expected road material and whose saturated hydraulic conductivity is approximately equal to the selected value. These values are summarized in Table 3 and in Appendix A. In addition, the road thickness was changed from $0.1 \mathrm{~m}$ to $0.3 \mathrm{~m}$ (roughly 12 in., to be consistent with the information previously cited).

Table 3: Compacted Fill Properties for Case \#2

\begin{tabular}{|c|c|c|c|c|c|c|}
\hline & $\begin{array}{c}\text { Saturated } \\
\text { Hydraulic } \\
\text { Conductivity } \\
(\mathrm{m} / \mathrm{s})\end{array}$ & $\begin{array}{c}\text { Residual } \\
\text { Saturation }\end{array}$ & $\begin{array}{r}\alpha \\
(1 / \mathrm{m})\end{array}$ & $\beta$ & $\begin{array}{c}\text { Bulk-Rock } \\
\text { Compressibility } \\
(1 / \mathrm{m})\end{array}$ & Fracture \\
Porosity & $\begin{array}{c}\alpha \\
\text { Porosity }\end{array}$ \\
\hline $0.15^{\mathrm{a}}$ & $5.00 \times 10^{-8 \mathrm{a}}$ & $0.07^{\mathrm{b}}$ & $0.500^{\mathrm{b}}$ & $1.09^{\mathrm{b}}$ & 0 & 0 \\
\hline
\end{tabular}

aparameters selected by the principal investigator.

bParameters based on those for silty clay from Carsel and Parrish (1988).

The calculational grid for Case \#2 was the same as that for the base case for Case \#1, except the road was made two element rows thick: the top row is $0.1 \mathrm{~m}$ thick, and the second row is $0.2 \mathrm{~m}$ thick. In situ saturation values were calculated with the alluvium in place where the road is located. After the steady-state calculations, the road was "installed"; it is $12 \mathrm{~m}$ wide with an additional 3-m-wide "shoulder." The road's centerline formed one vertical boundary across which there is no flow. The boundary condition for the 6- $\mathrm{m}$ road section during the elevated saturation period was $100 \%$ saturation. The boundary condition for the shoulder and for the remaining alluvial surface was the ET model described earlier. The last assumption is that after the compacted fill material is installed, the total in situ pressure head in the fill material and in the undisturbed alluvium are assumed equal. When the compacted road material was then put in place of the alluvium at the road, without changing the total pressure head, a calculated value for in situ saturation in the compacted fill was $77 \%$; this saturation correlates to an in situ moisture content of $11.6 \%$, within the expected range as observed by Reynolds Electrical and Engineering Company (REECO) personnel.

The results of the calculations for Case \#2 indicate that a compacted road fill material can substantially impede the movement of surficially-applied water into and through the alluvium. Figure 16 shows the in situ saturation in the road, alluvium, and the top portion of the TCw; the only difference between this profile and the one for Case \#l is the saturation level in the compacted fill road. Figures 17 through 19 show the movement of water resulting from 1, 2, and 5 years of road watering, respectively. The amount of water infiltrating the compacted road after 5 years is about $3.15 \mathrm{~m}$, or about $14 \%$ of that which infiltrates when the water is applied directly to the alluvium in Case \#1. Figure 20 shows the resulting change in saturation after 10,000) years. For water addition over a 10-year period, a similar pattern to that in Case \#1 develops, in that the water sinks to the alluvium-TCw interface and spreads out laterally; Figures 21 through 23 show the results of 8 and 10 years of water, and the change in saturation resulting from that water through 10,000 years, respectively. For water addition over a 15 -year period, the total amount 
that has infiltrated the compacted road is $9.7 \mathrm{~m}$, still only $40 \%$ of the amount that infiltrates the alluvium in Case \#1 in 5 years. Figures 24 and 25 show this water at 15 and 10,000 years, respectively. Figure 26 compares the saturation along the road centerline at $0,5,10$, and 15 years of watering; note that the water just begins to enter the PTn unit after 15 years. Figure 27 shows the vertical extent of the water movement through 10,000 years resulting from each elevated saturation period. No significant change in saturation occurs below $100 \mathrm{~m}$ above TSw 2 for 15 years of surficial watering; for 5 years, the depth of water movement is less extensive, to about $150 \mathrm{~m}$ above TSw2. A comparison of the cumulative net flux of water for Case \#1 both with and without the ET model and for Case \#2 is illustrated in Figure 28. The compacted fill modeled here effectively reduces the amount of infiltration by an order of magnitude. From all the figures shown, it is apparent that the storage and transport of water through the subsurface can be greatly diminished by constructing roads and pads of a compacted fill material characterized by lower porosity and hydraulic conductivity than alluvium. 


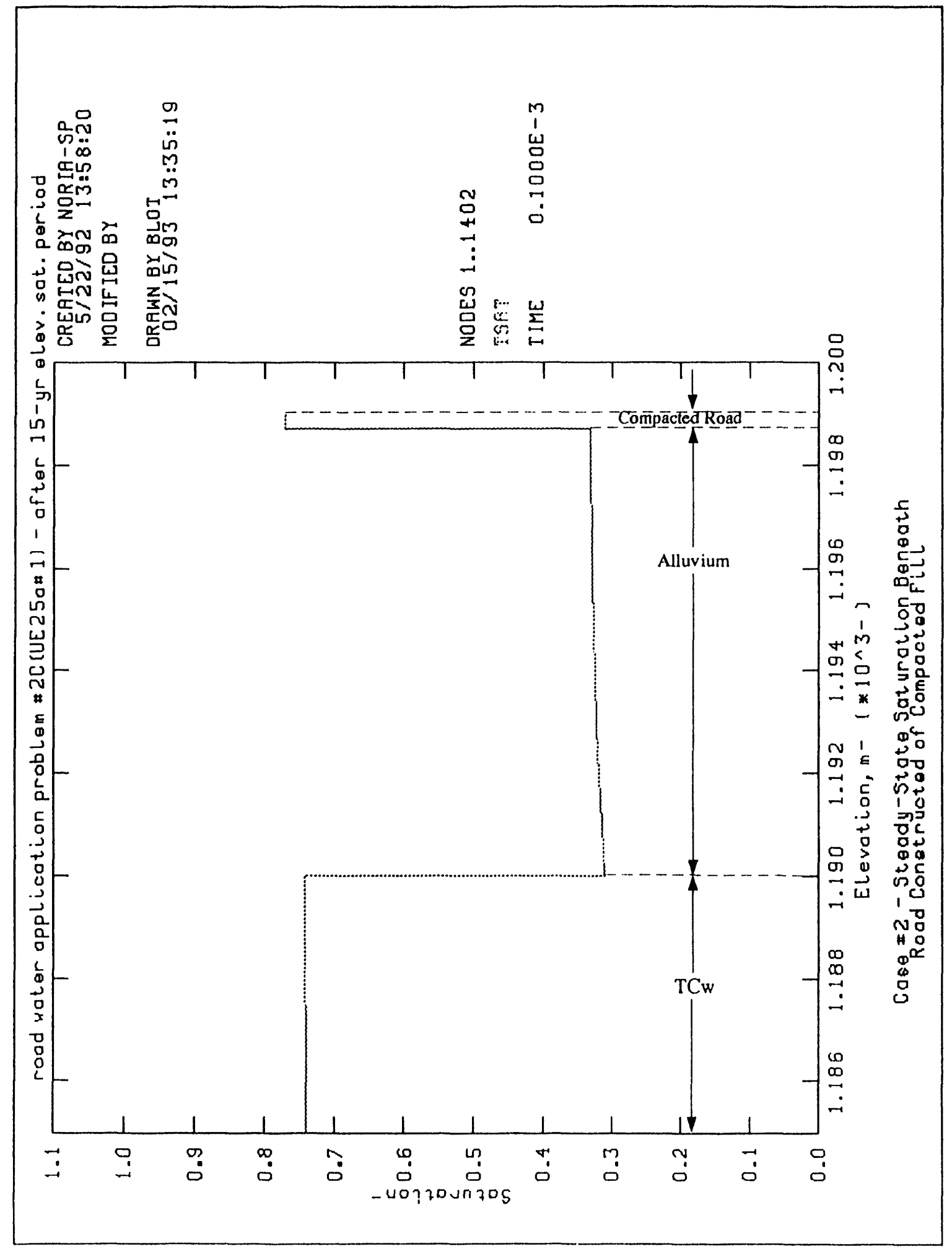

Figure 16: Case \#2 - Steady-State Saturation Profile in the Compacted Fill Road and the Underlying Alluvium and TCw 


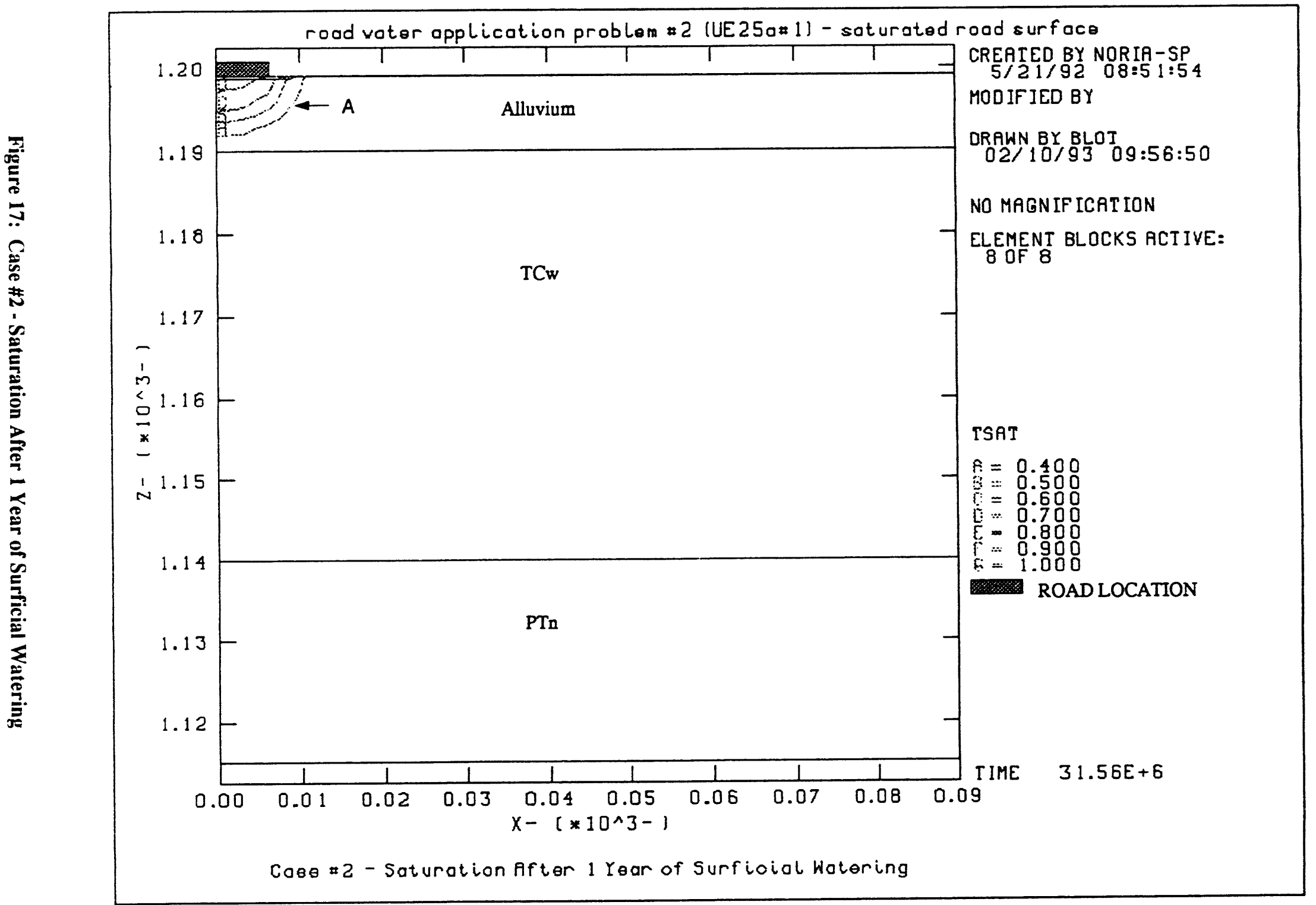




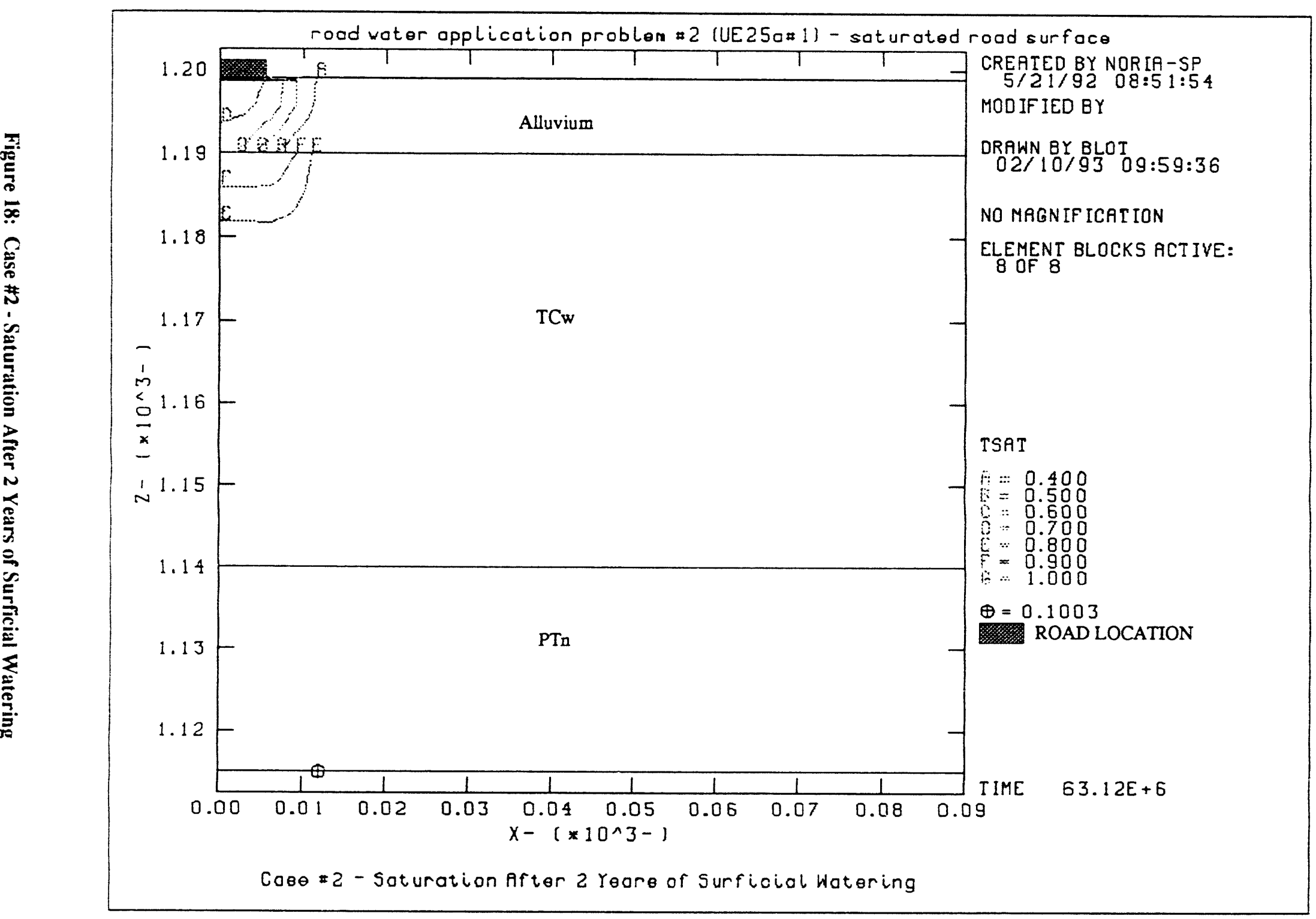




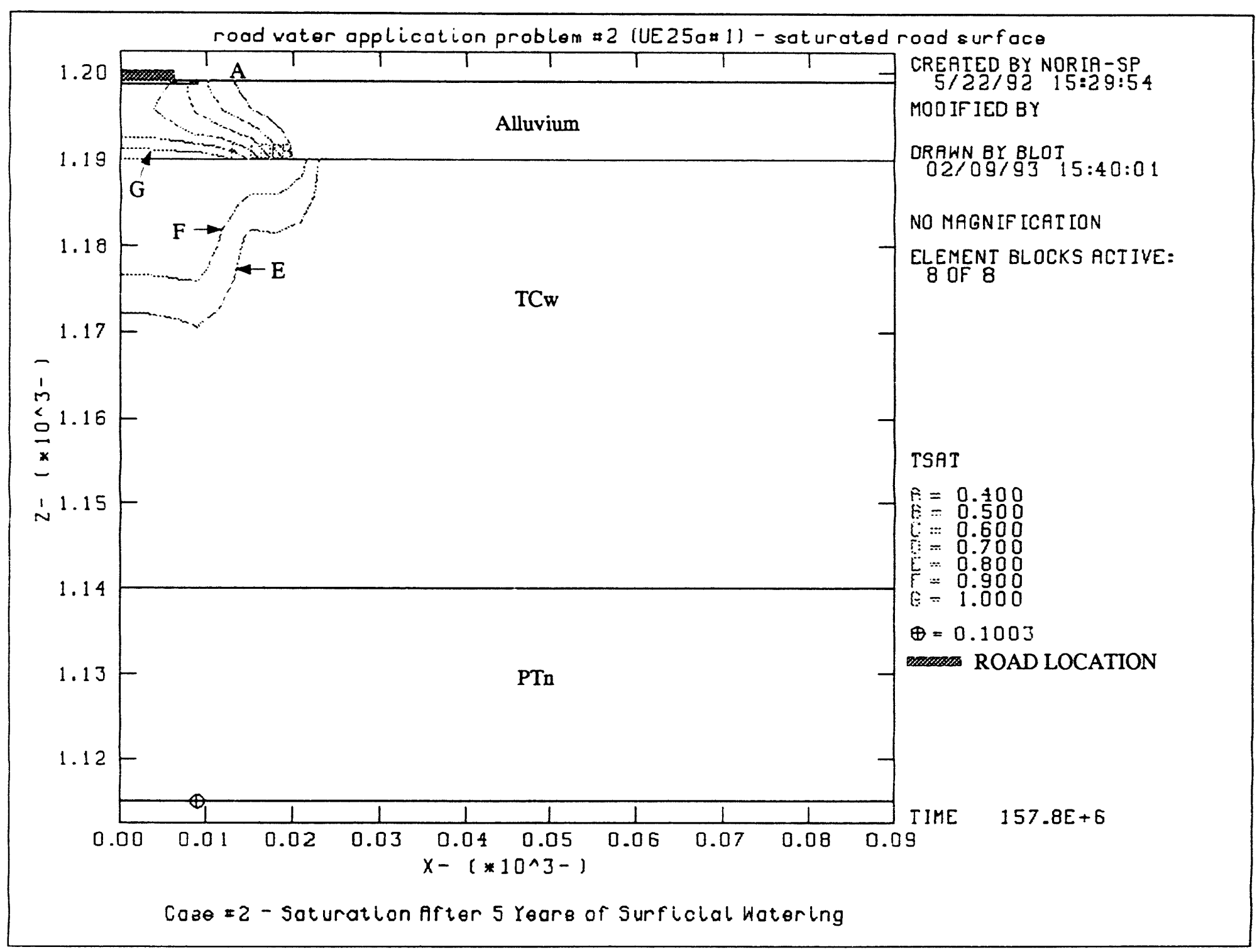




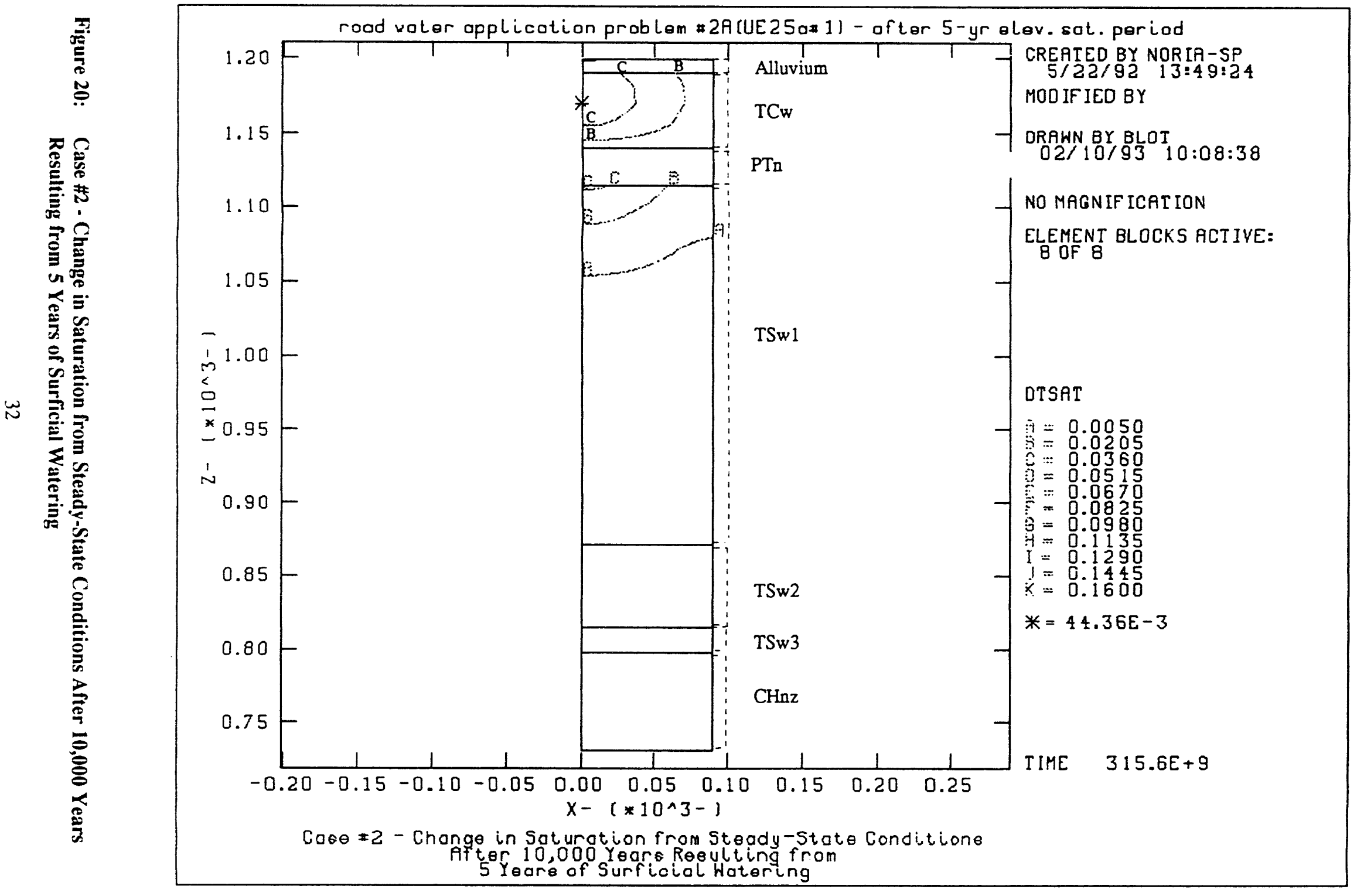




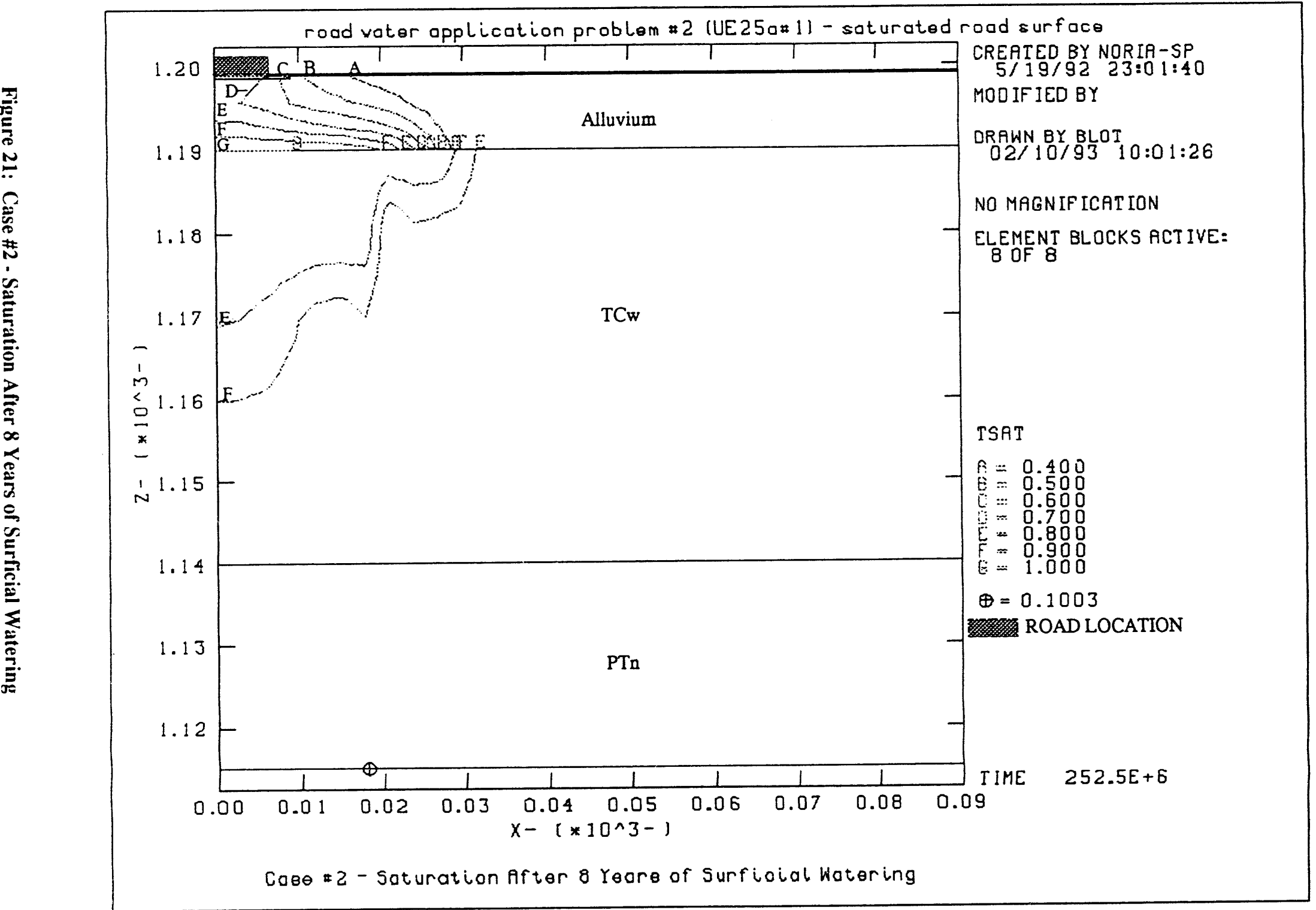




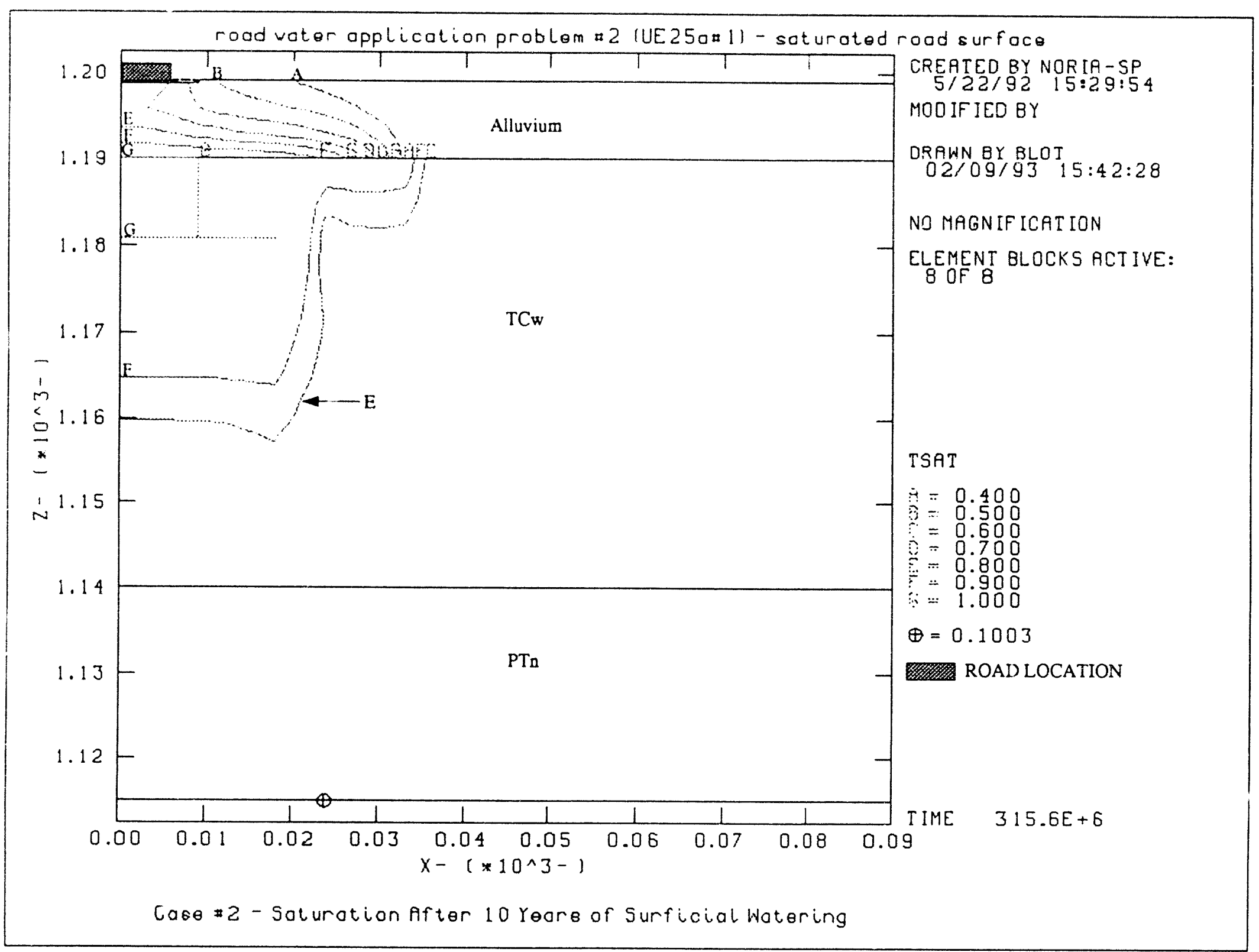




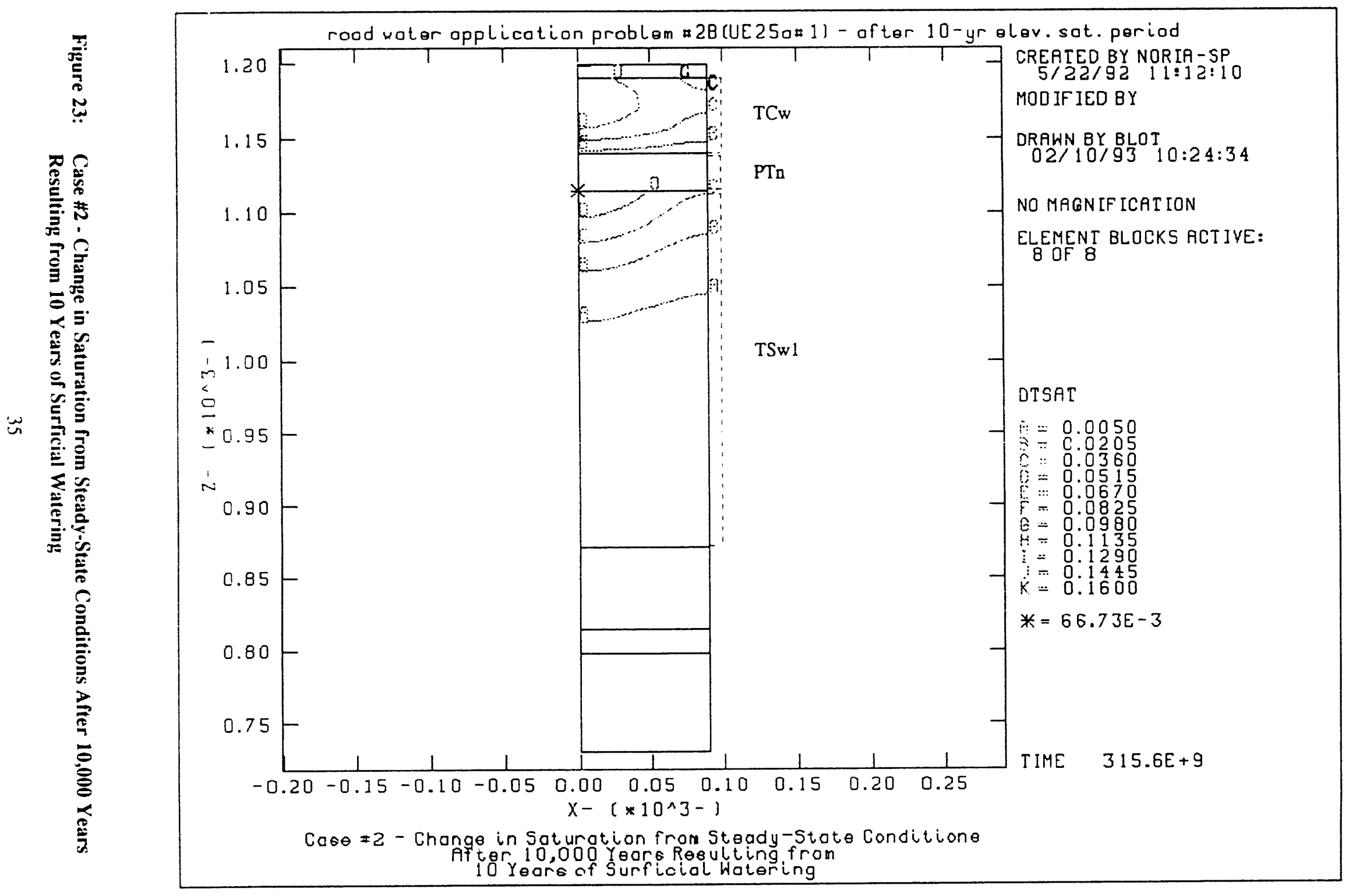




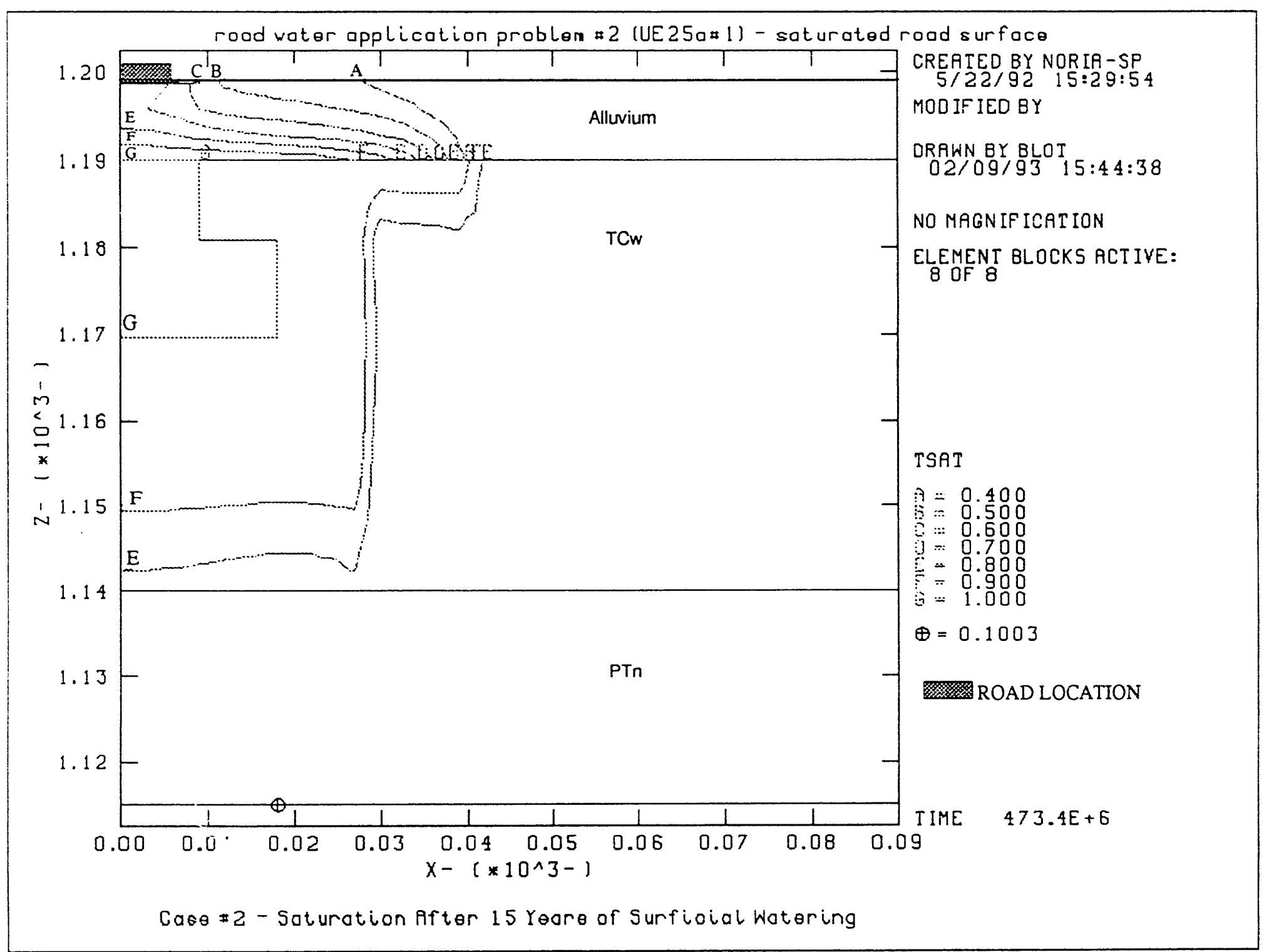




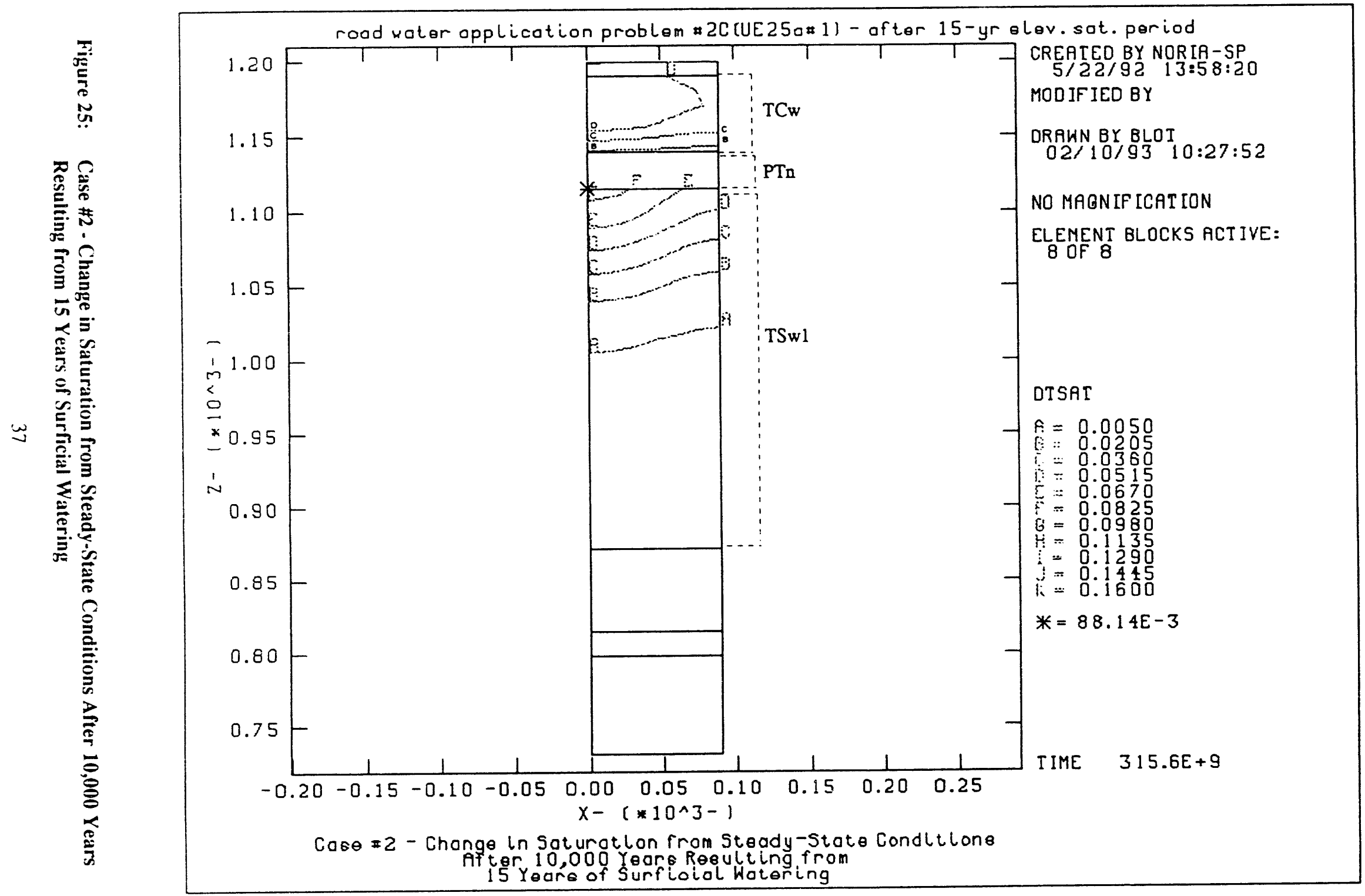




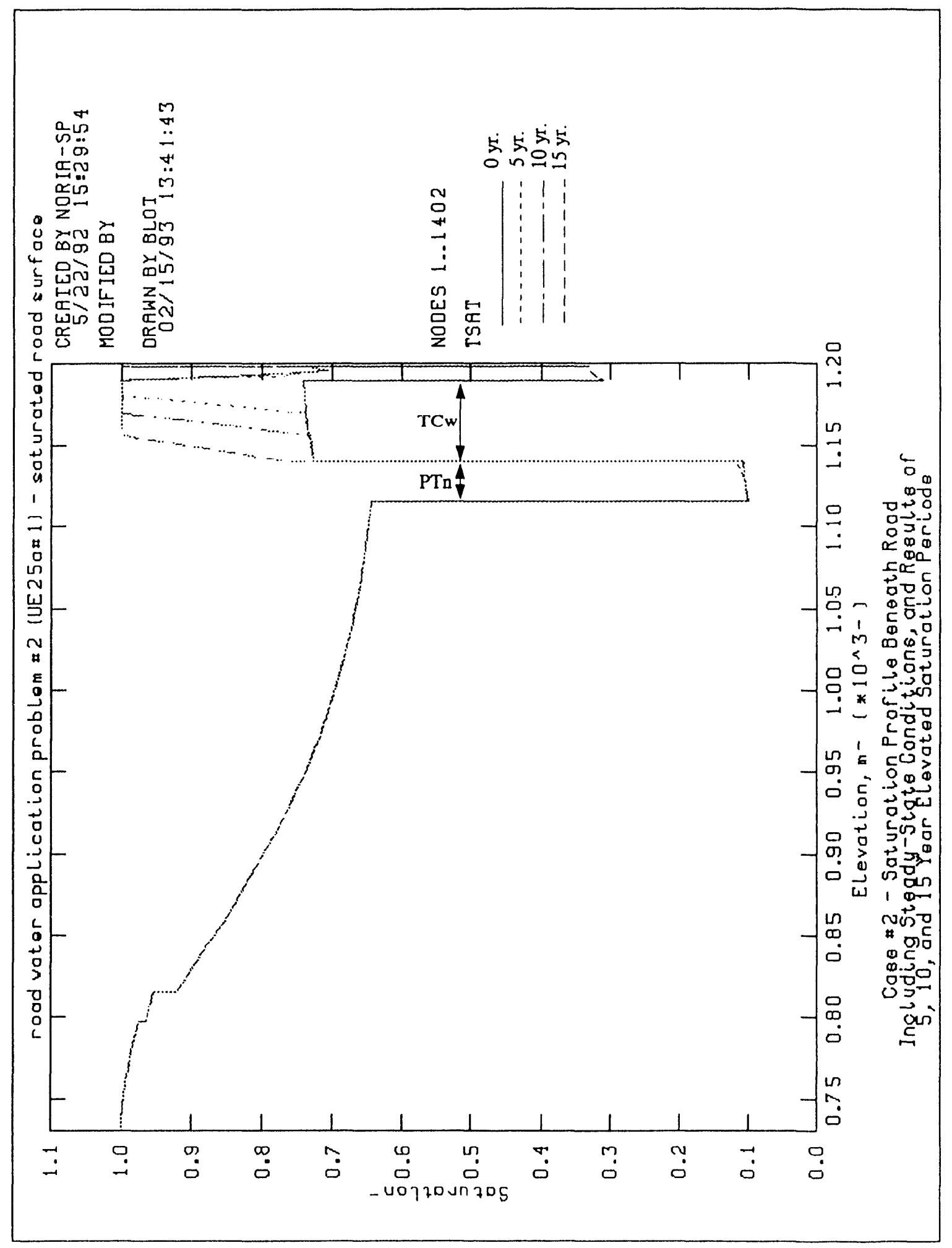

Figure 26: Case \#2 - Saturation Profiles at 0, 5, 10, and 15 Years of Surficial Watering 


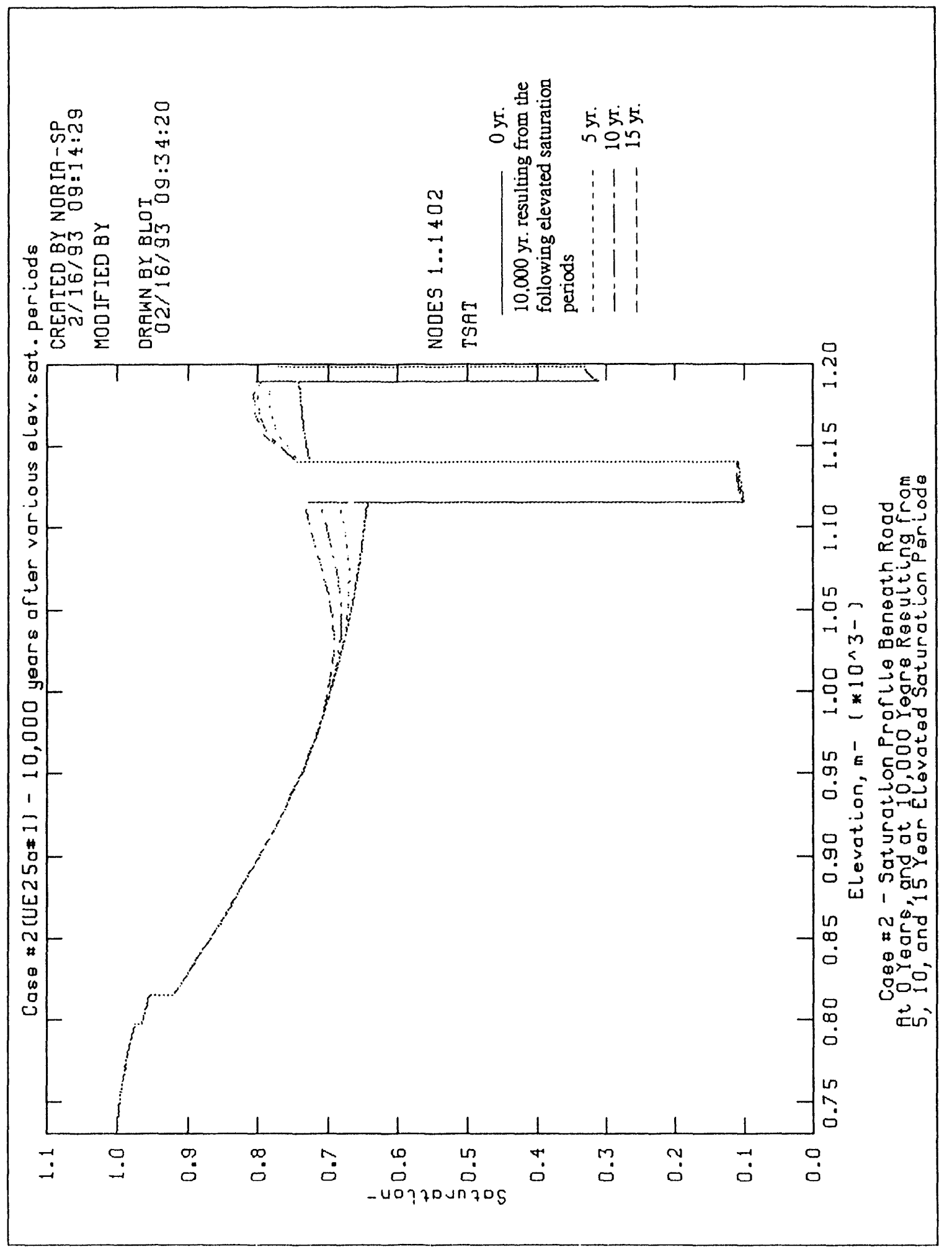

Figure 27: Case \#2 - Saturation Profiles at 0 Years, and at 10,000 Years Resulting from 5-, 10-, and 15-Year Elevated Saturation Periods 

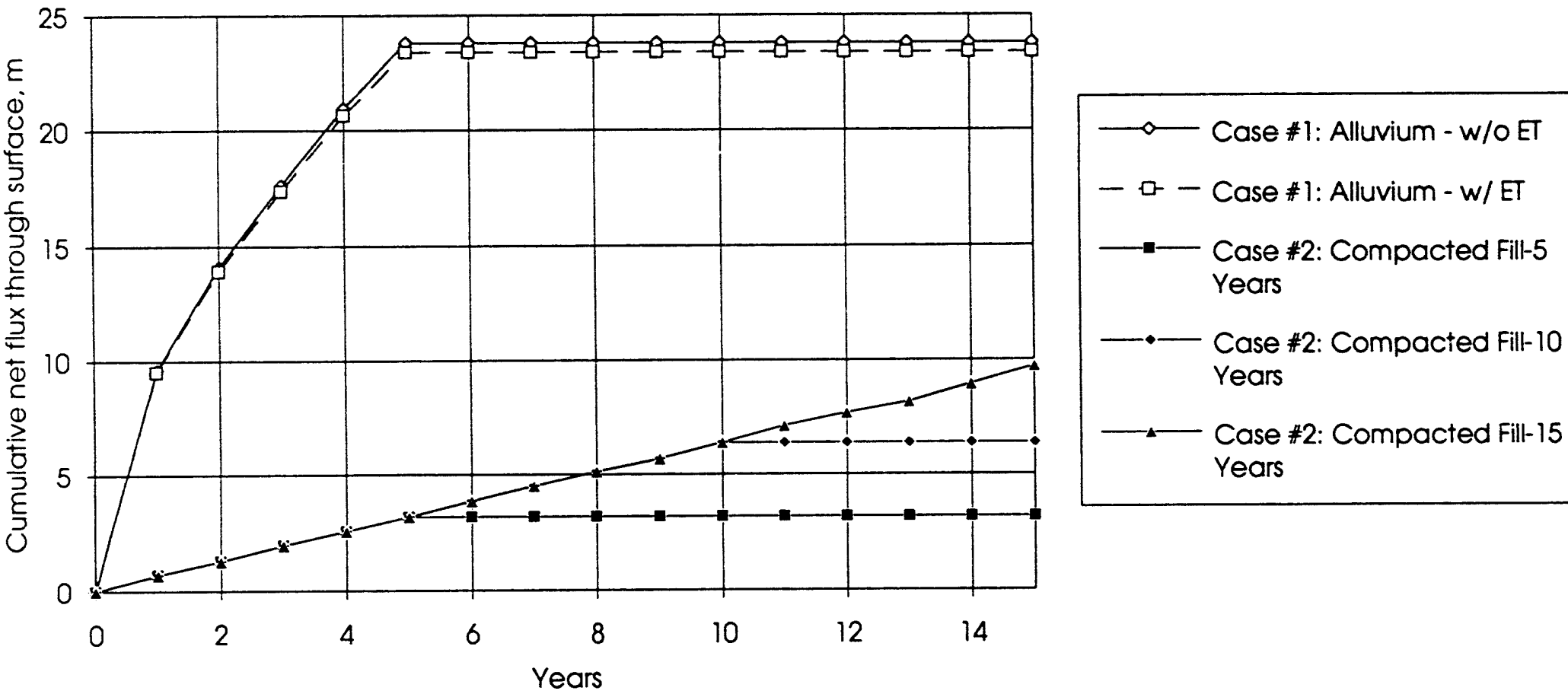


\subsection{Case \#3: Water Movement in the Vicinity of UZ-16}

The calculations for Case \#3 were similar in nature to those for Case \#1. The major difference between the two cases is the stratigraphy; Case \#3 uses the expected stratigraphy of the borehole UE-25 UZ-16 (see Appendix A for the stratigraphy). The UZ-16 stratigraphy has $10 \mathrm{~m}$ of alluvium at the surface and $61 \mathrm{~m}$ of TCw, compared with $9 \mathrm{~m}$ of alluvium and $50 \mathrm{~m}$ of TCw for the UE-25a \#1 stratigraphy used for Case \#1. The calculations for Case \#3 employed a computational grid containing 30 columns and 42 rows of elements, for a total of 1260 finite elements (see Figure 29). The computational domain was $90 \mathrm{~m}$ wide, and the centerline of the road formed the vertical boundary at the origin (left side). The bottom boundary was the water table level near the UE-25 UZ-16 location (Robison, et al., 1988), and the ground surface formed the top boundary. The alluvium was divided into two parts. The top $0.1 \mathrm{~m}$ of the alluvium formed the top row of elements, and was designated as the row that contained the road. This road layer is thin to minimize the artificial addition of water to the alluvium as a result of forcing the top row of nodal points in the road section to $100 \%$ saturation.

Figure 30 illustrates the in situ saturation levels throughout the stratigraphy resulting from the steady-state infiltration rate of $0.01 \mathrm{~mm} / \mathrm{yr}$.. The alluvium directly beneath the road was saturated after about 1 year (Figure 31). During this time, approximately $10.7 \mathrm{~m}$ of water had infiltrated through the road surface. Because of the relatively low conductivity of the underlying Tiva Canyon unit, movement of water along the alluvium- $\mathrm{TCw}$ interface was much more significant than infiltration of the water into the TCw and underlying stratigraphy. At 5 years, the calculations indicated that approximately $27 \mathrm{~m}$ of water (areally averaged) had infiltrated the alluvium through the wetted alluvium road, and water had moved to nearly $70 \mathrm{~m}$ away from the edge of the road. Figure 32 shows the saturation in the top three hydrologic units after 5 years, and Figure 33 shows $\Delta$ sat after 5 years. At this point, road watering was discontinued and the steady-state infiltration of $0.01 \mathrm{~mm} / \mathrm{yr}$ was restored to the entire surface. The plots of $\Delta$ sat in Figures 34 and 35 show that water is nearing the edge of the computational domain after 10 years of activity, and had reached the edge after 15 years. Therefore, lateral water movement was artificially restrained, and vertical migration was exaggerated, for the remainder of the calculations. A comparison of the saturation throughout the stratigraphy along the road's centerline between in situ conditions and those conditions at 5 and 10,000 years (Figure 36) shows no change in in situ conditions below $240 \mathrm{~m}$ above the water table, or about $20 \mathrm{~m}$ above the elevation of the closest portion of the proposed repository horizon.

The results of Case \#3 are similar to those for Case \#1; alluvium acts as an effective storage and transport medium for water. The thicker alluvium layer used in Case \#3 absorbed more water and more quickly spread it laterally than the layer used in Case \#1. A more quantitative evaluation of this phenomenon is discussed in Section 4.0. 


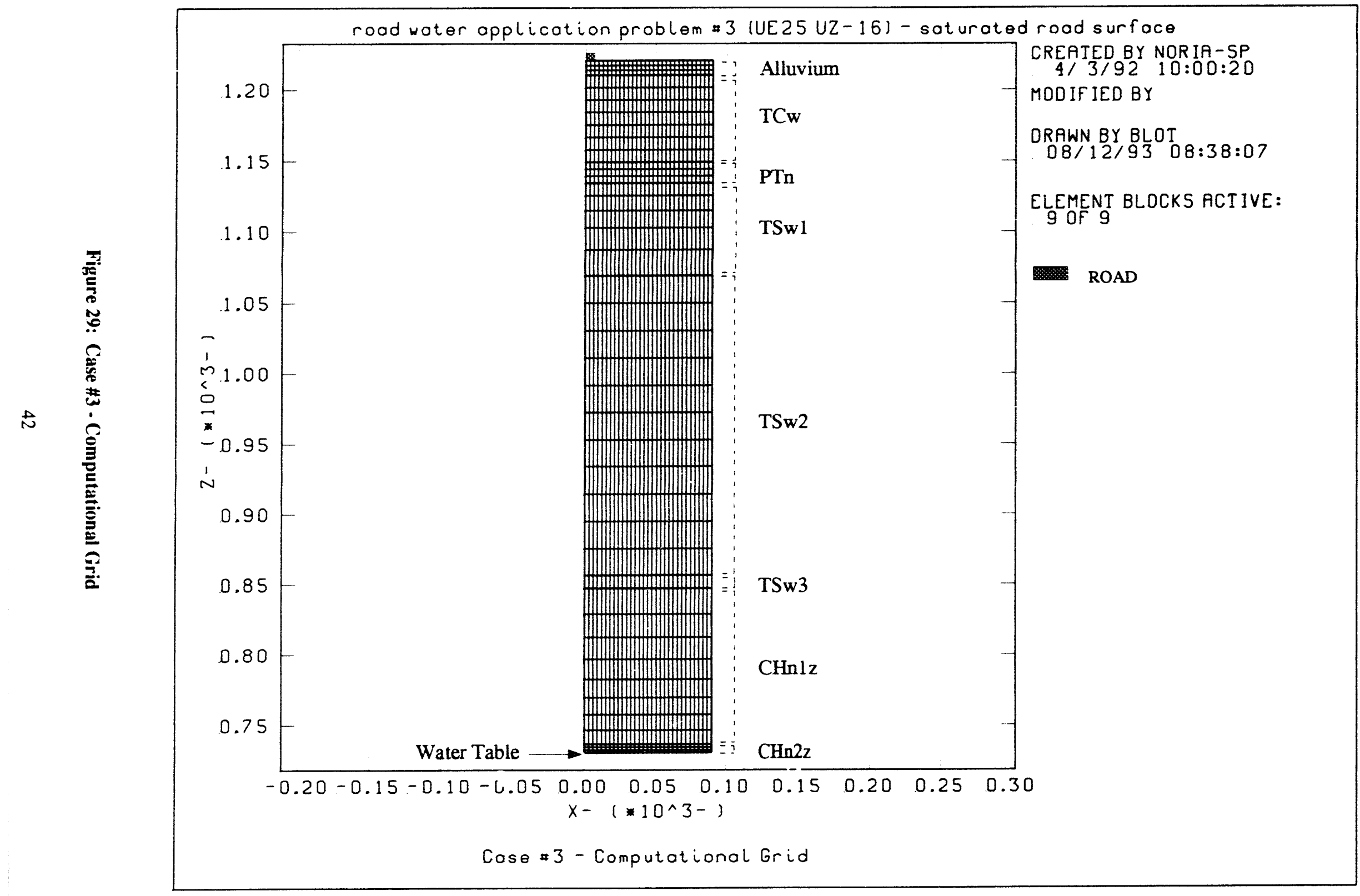




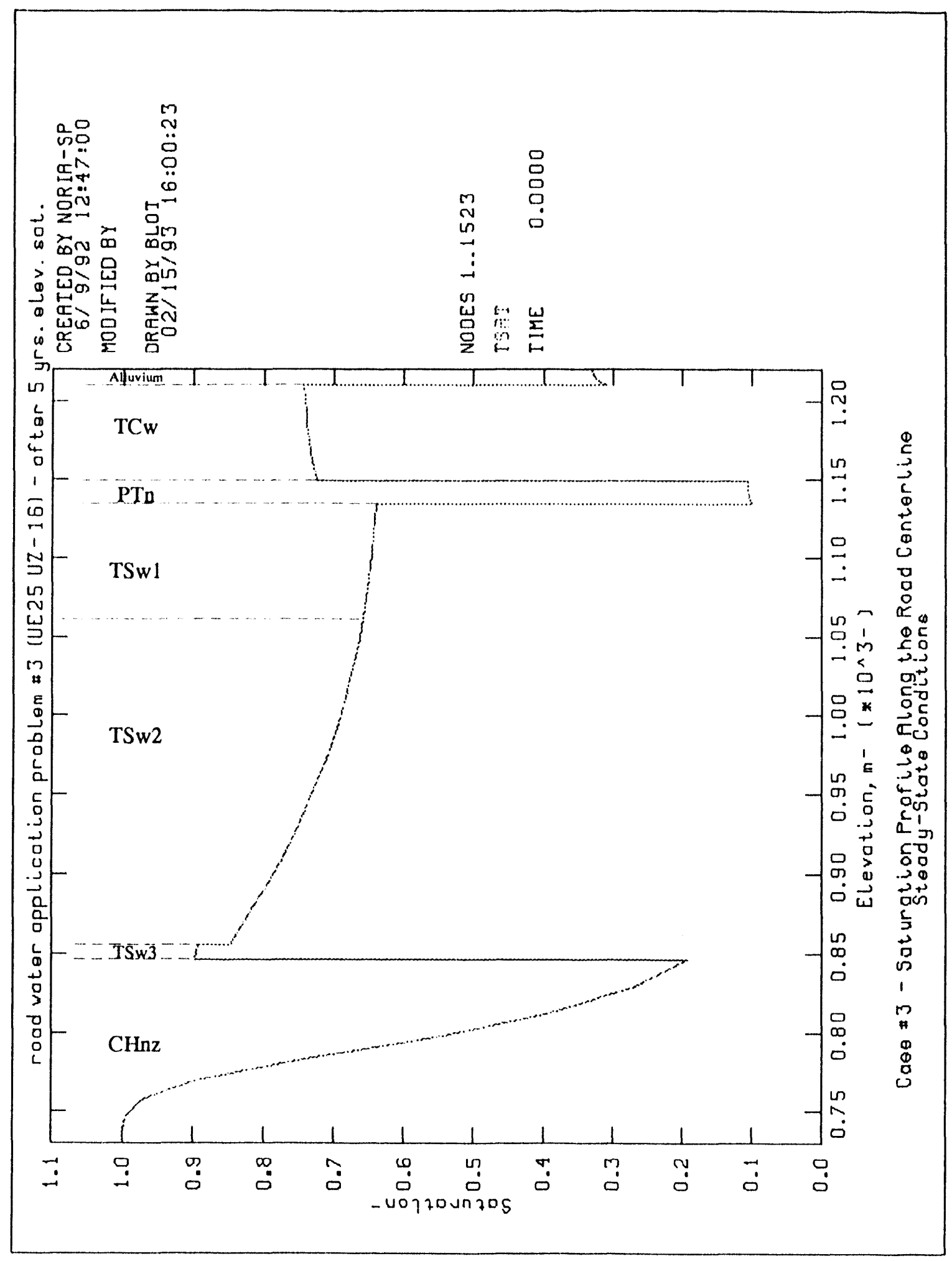

Figure 30: Case \#3 - Steady-State Saturation Profile 


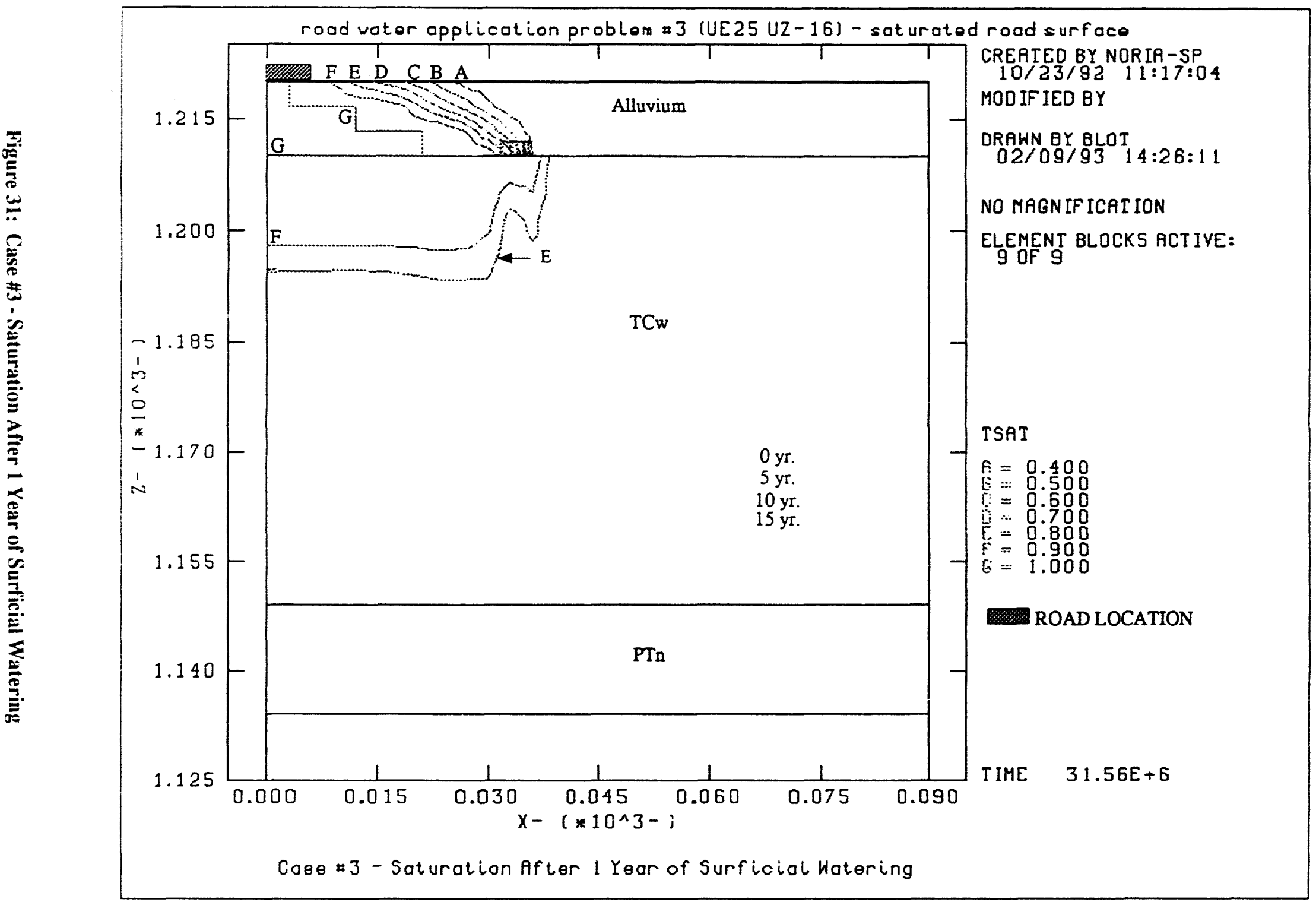




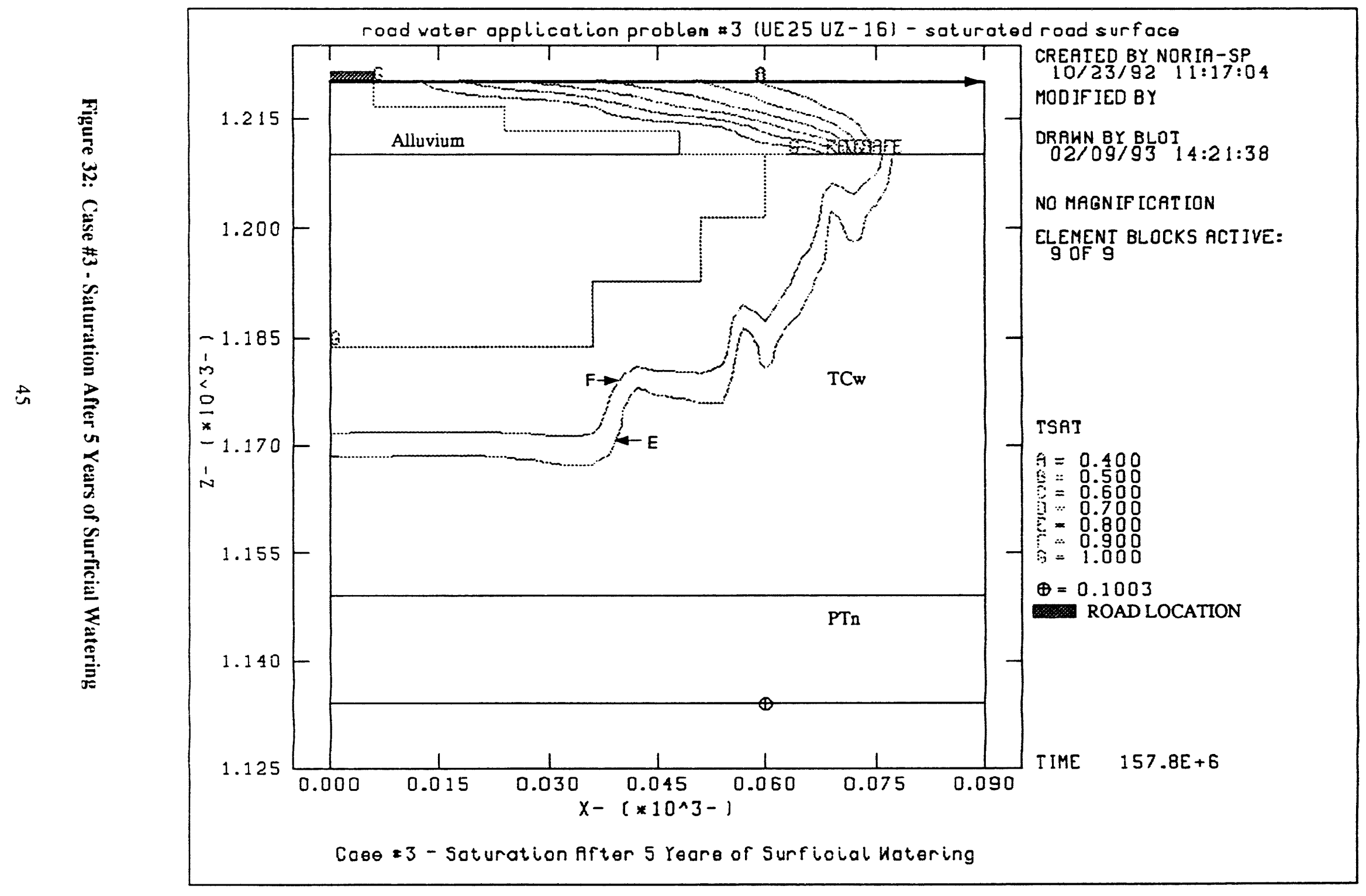




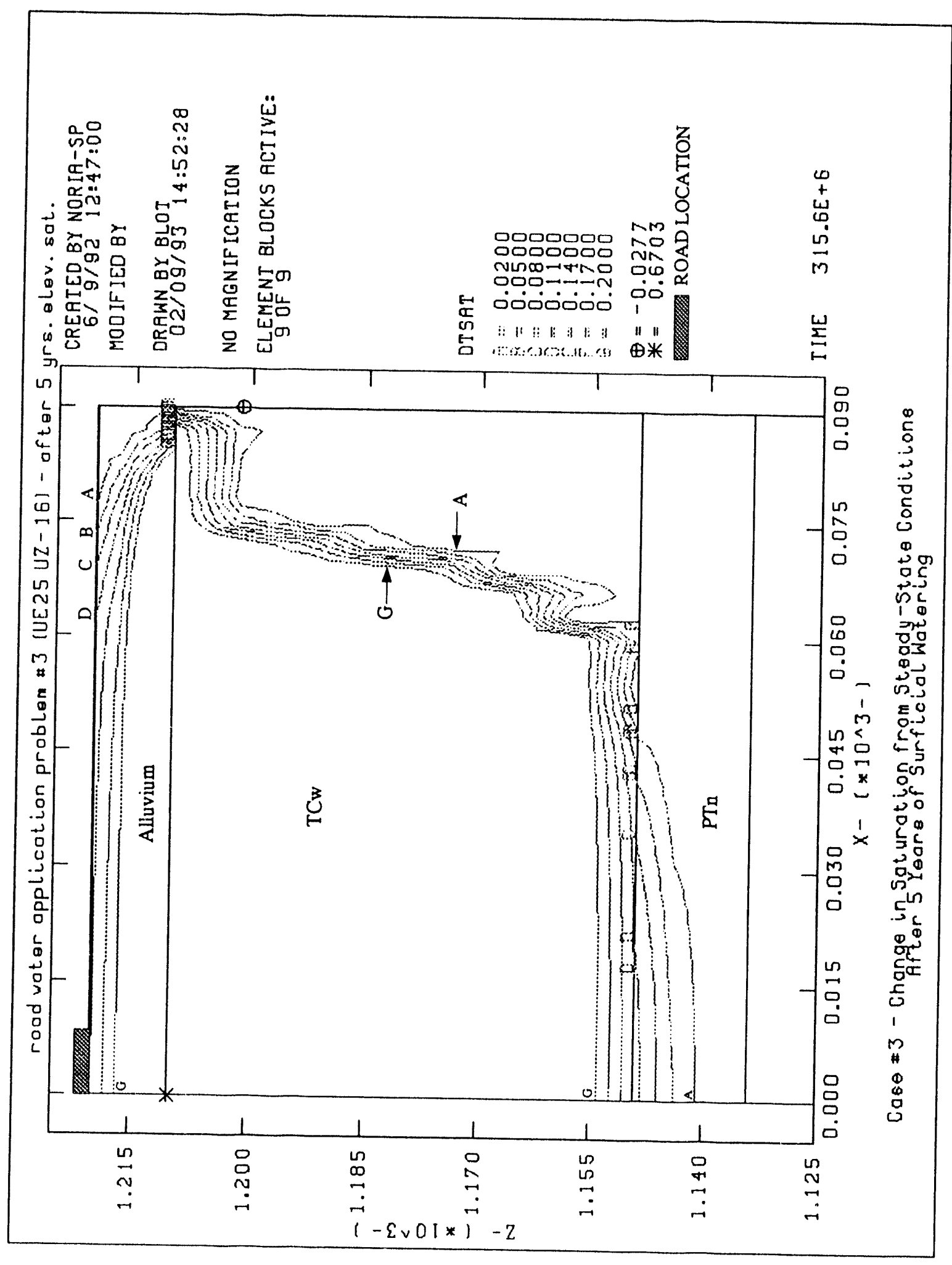

Figure 33: Case \#3 - Change in Saturation f: om Steady-State Conditions After 5 Years of Surficial Watering 


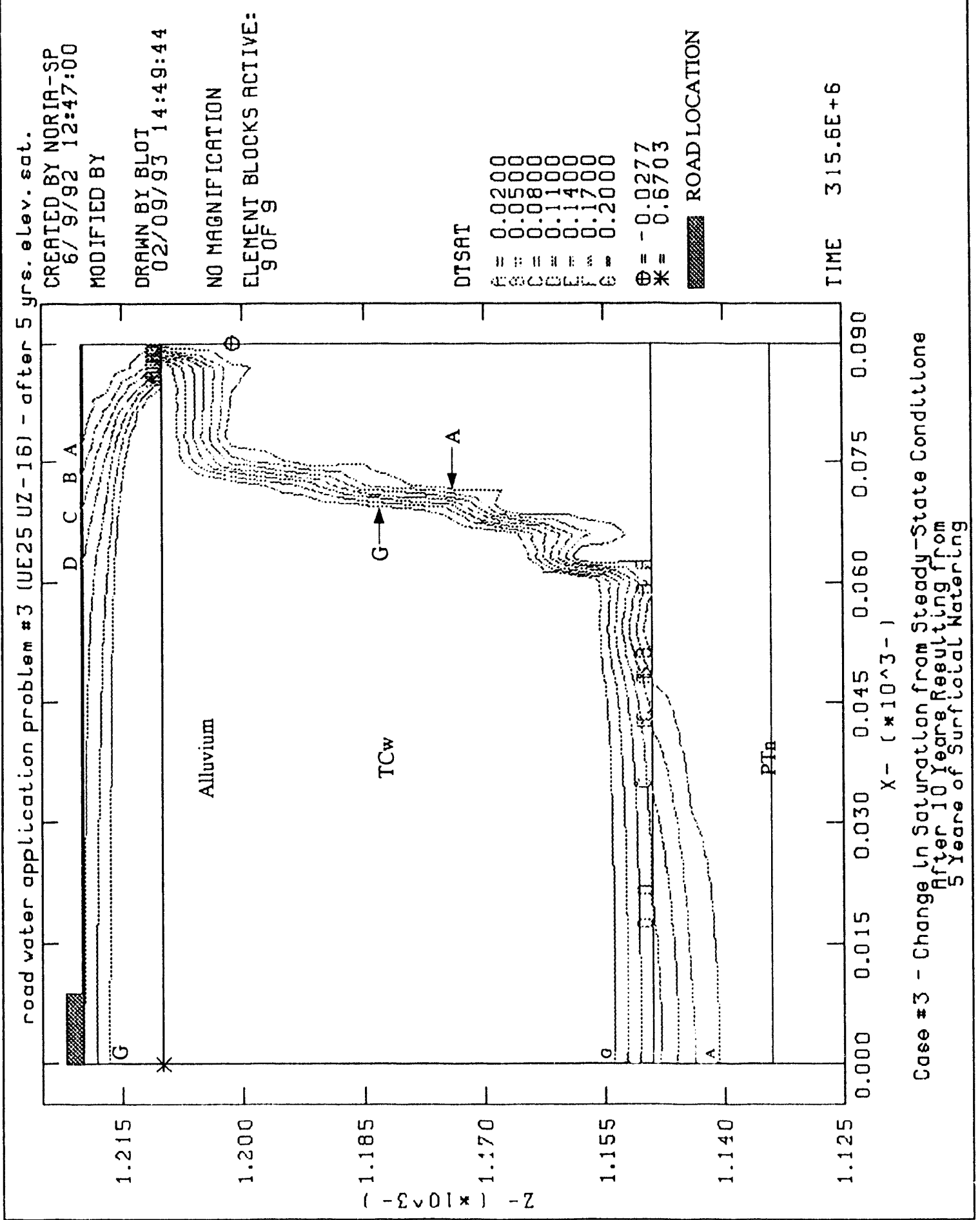

Figure 34: Case \#3 - Change in Saturation from Steady-State Conditions After 10 Years Resulting from 5 Years of Surficial Watering 


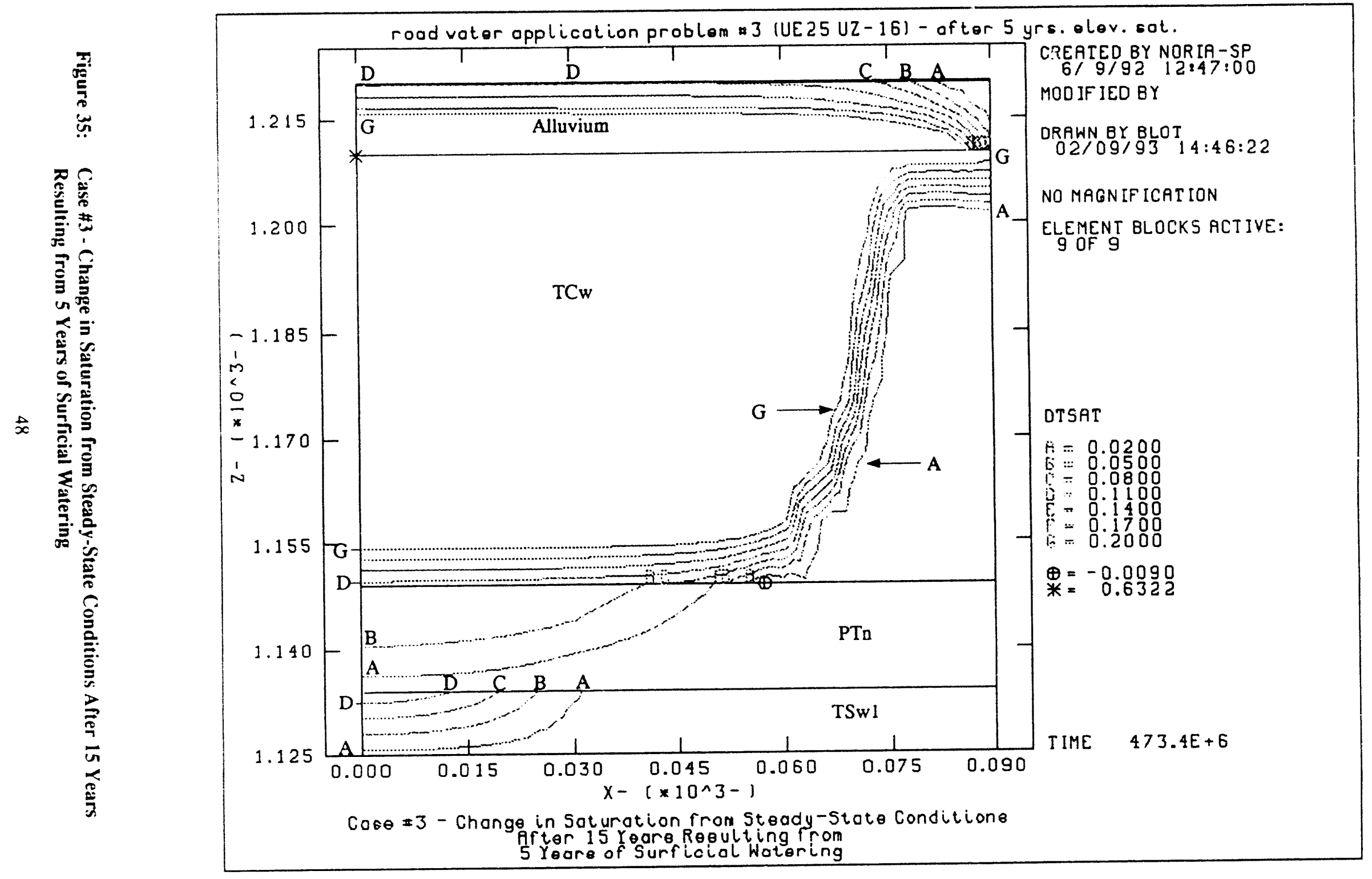




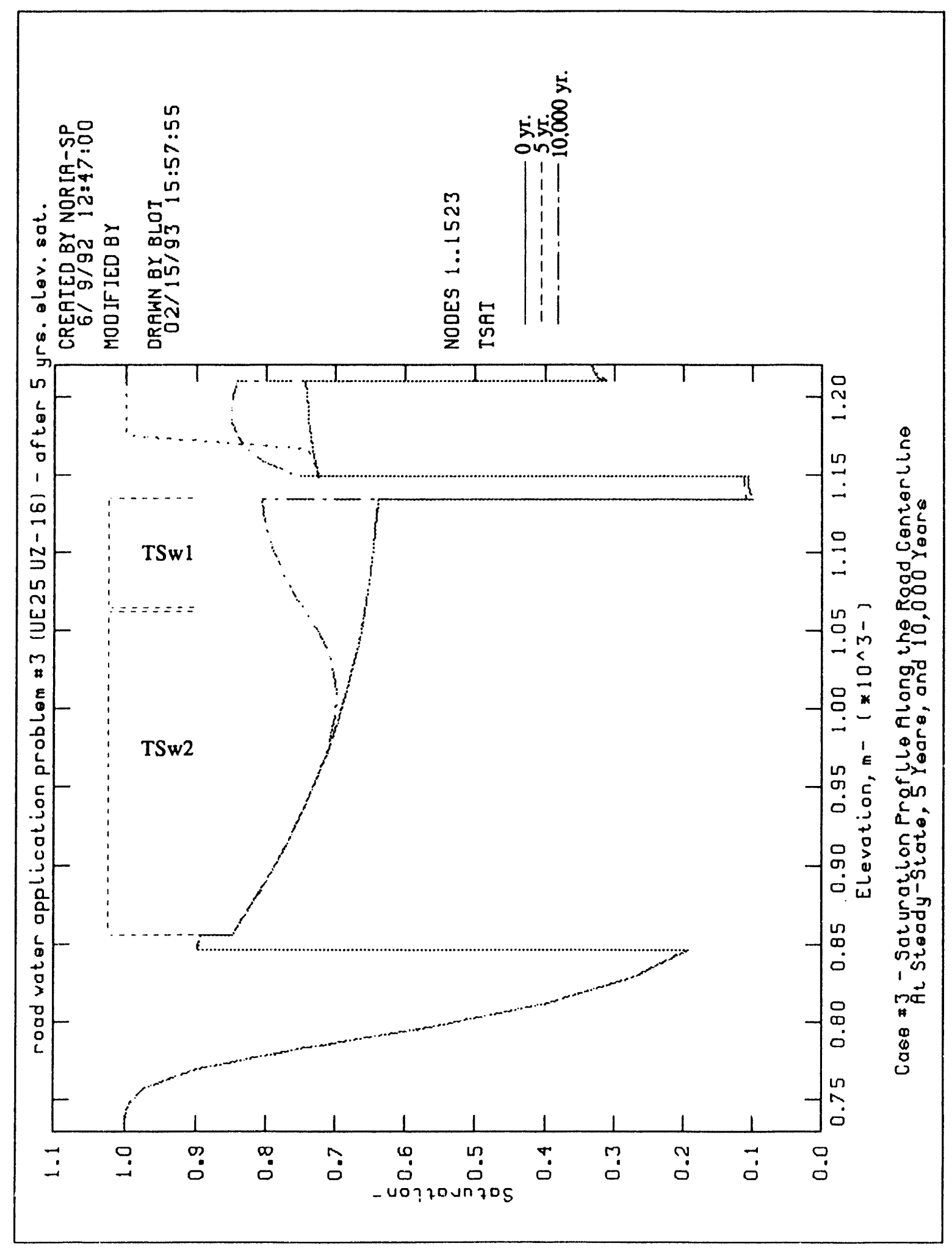

Figure 36: Case \#3 - Saturation Profiles for 0, 5, and 10,000 Years 


\subsection{Case \#4: Water Movement in the Vicinity of UZ-16 Considering the Expected Imbricate Faulting}

As described in Table 1, calculations to be performed for Case \#4 were to be used to estimate the sensitivity of calculational results to a more highly fractured stratigraphy than is usually modeled. It had been anticipated that the borehole UE-25 UZ-16 would be drilled through an imbricate fault zone, where higher fracture densities might be expected, particularly in the TCW and TSw $1 /$ TSw2 units. The values for fracture properties used in this report for the other cases listed in Table 1 are those which have been compiled from a number of sources and listed in Klavetter and Peters (1986). The two most important parameters listed are fracture aperture and fracture density. The values for fracture aperture are taken from data obtained from the borehole USW G-4 (Peters et al., 1984). The values for fracture density are based on measurements from the borehole USW GU-3 (Scott and Castellanos, 1984). It was learned from personnel at the USGS that for the design of the construction of UE-25 UZ-16, the fracture density values expected for UZ-16 are practically the same as those encountered in USW GU-3.5 Because the anticipated fracture properties of the UZ-16 borehole are equivalent to the currently-used values, any values that might have been used for the calculations for Case \#4 would be based on semi-educated speculation. As the value of such calculations for this performance assessment effort was questionable, it was decided that to cancel calculations for Case \#4 until new drill hole data or a sufficient need warrant an analytical effort.

\subsection{Case \#5: Water Movement Near USW H-5 Using a Horizontal Stratigraphic Model}

The location for Case \#5, borehole USW H-5, is on the top ridge of Yucca Mountain just inside the proposed repository block. This location was chosen to determine the potential effects of surficial water applied at a site off and uphill from the proposed repository block. The surface terrain at the top of Yucca Mountain is characterized by a thin layer of soil overlying the highly non-porous TCW unit; TCW was designated as the surface layer as defined in the RIB for USW H-5. (See Appendix A for this stratigraphy.) The calculations for Case \#5 employed a computational grid containing 20 columns and 54 rows of elements, for a total of 1080 finite elements (see Figure 37). The stratigraphic layers were modeled as horizontal and parallel. The computational domain was $40 \mathrm{~m}$ wide, and the centerline of the road formed the vertical boundary at the origin (left side). The bottom boundary was the water table level near the USW H-5 location (Robison et al., 1988), and the ground surface formed the top boundary. The TCW was divided into two parts. The top $0.1 \mathrm{~m}$ of $\mathrm{TCw}$ formed the top row of elements and was designated as the row that contained the road. This road layer is thin to minimize the artificial addition of water to the alluvium as a result of forcing the top row of nodal points in the road section to $100 \%$ saluration

Figure 38 shows the steady-state saturation conditions throughout the entire stratigraphy. The diminished storage and transport capabilities of the $\mathrm{TCw}$ bedrock are indicated dramatically in Figure 39, which shows the saturation in the mountain after 5 years of surficial watering. At this point, only $0.93 \mathrm{~m}$ of water had infiltrated through the road. The plot of $\Delta$ sat at 5 years in Figure

5 A more detailed documentation of the fracture properties and the discussions with USGS personnel may be found in the analysis file for PDM 72-32, located in the SNL, YMP Local Records Center. 
40 indicates that the water has moved to only about $11 \mathrm{~m}$ away from the road's edge. The calculations for 15 years of surficial water application, as plotted in Figures 41 (saturation) and 42 ( $\Delta$ sat), continue to reveal the poor storage capability of $\mathrm{TCw}$. The amount of water, averaged over the road area, that infiltrated the mountain through the road in 15 years was $2.9 \mathrm{~m}$. There is not the substantial lateral dispersion of water that was witnessed in Cases \#1 and \#3. Figure 43 illustrates the results of 10,000 years of water movement after the 15-year elevated saturation period; this figure indicates that all the water remains in the TCw unit through 10,000 years. In fact, the water reached the edge of the 40-m-wide computational grid between 100 and 1000 years, so the resulting numerically-imposed constraint on the water movement may have artificially increased the extent of vertical transport of the water that would be predicted by the computational flow model. These calculations support earlier conclusions that the TCw unit is a poor storage and transport medium for water. 


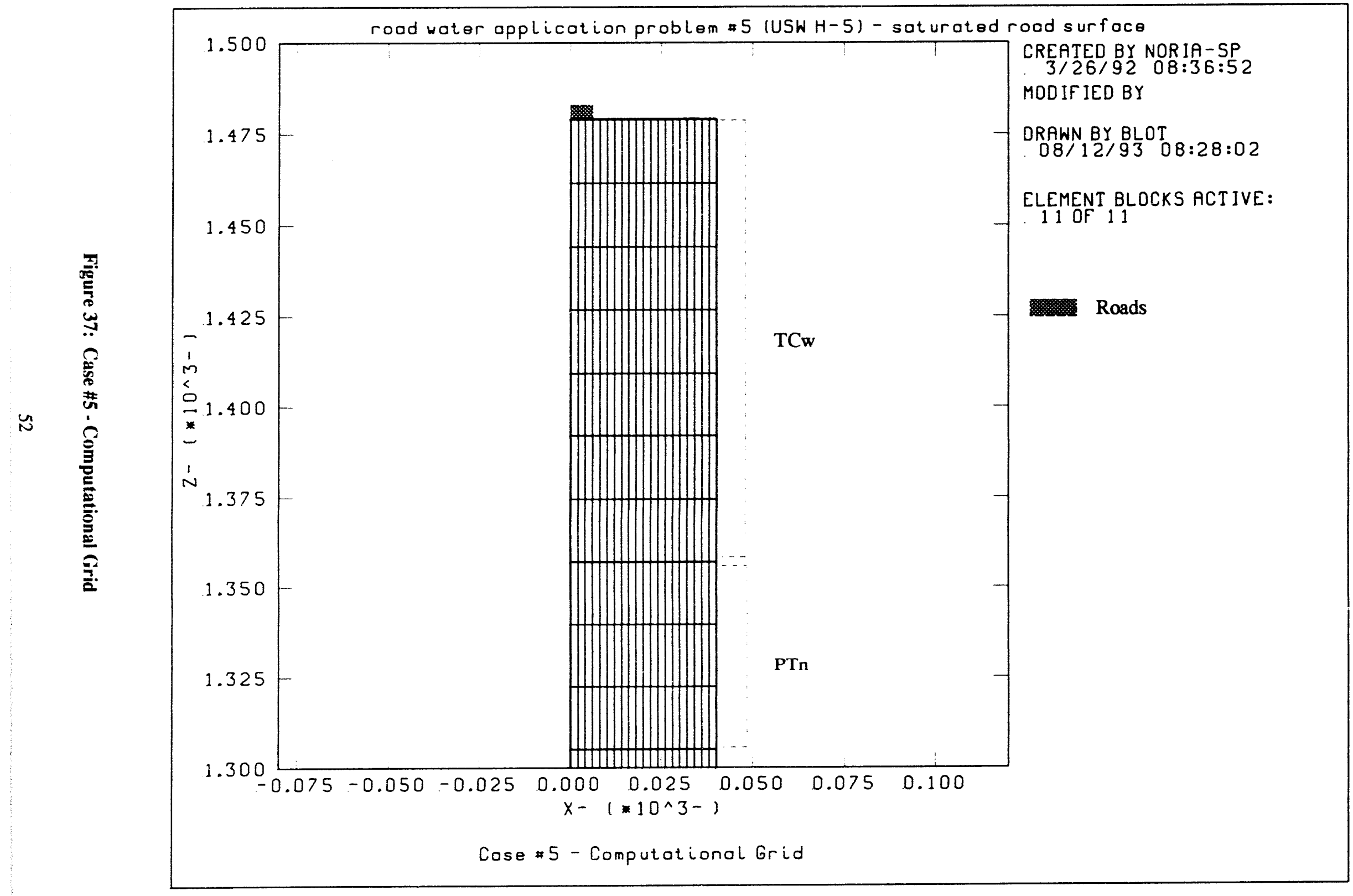




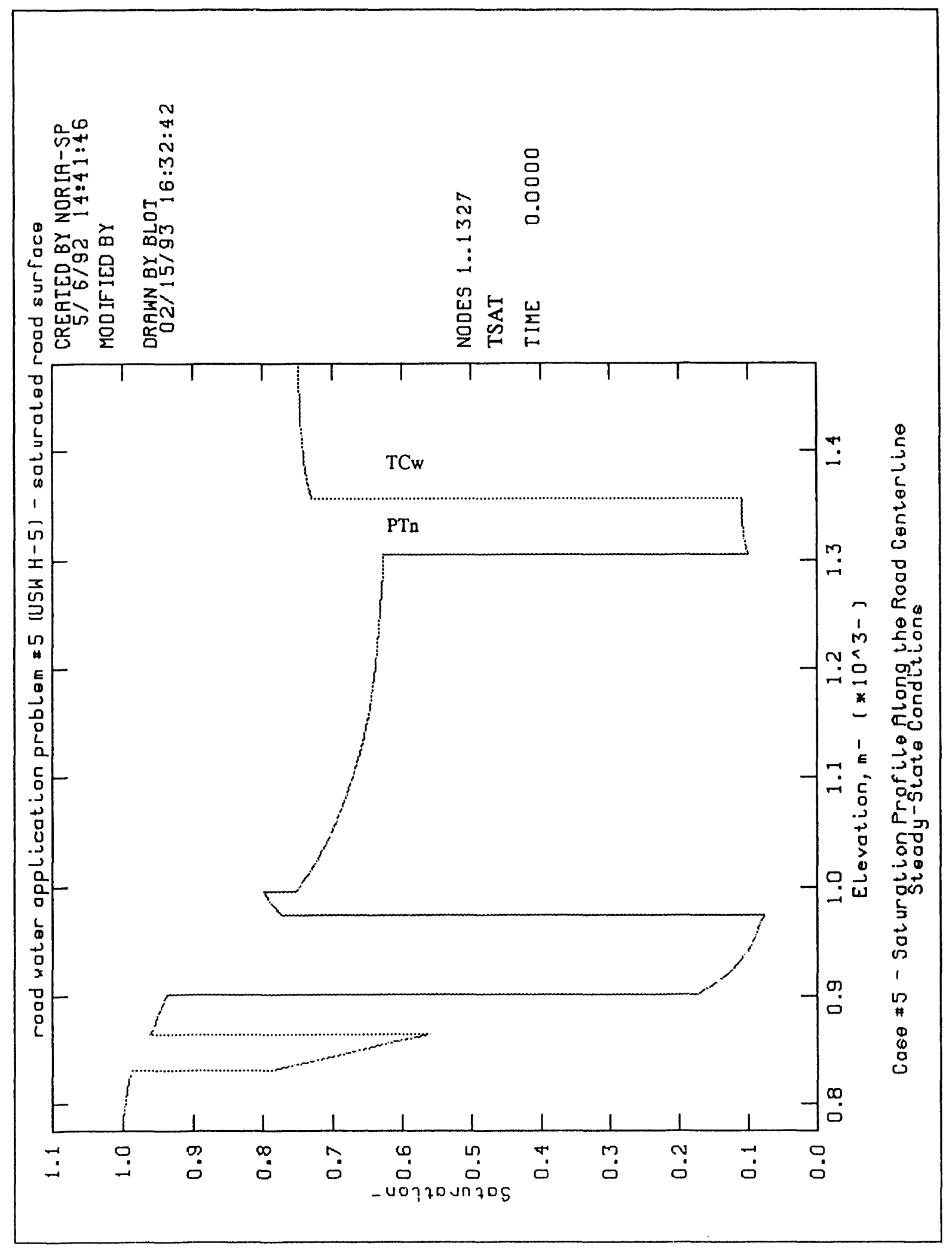

Figure 38: Case \#5 - Steady-State Saturation Profile 


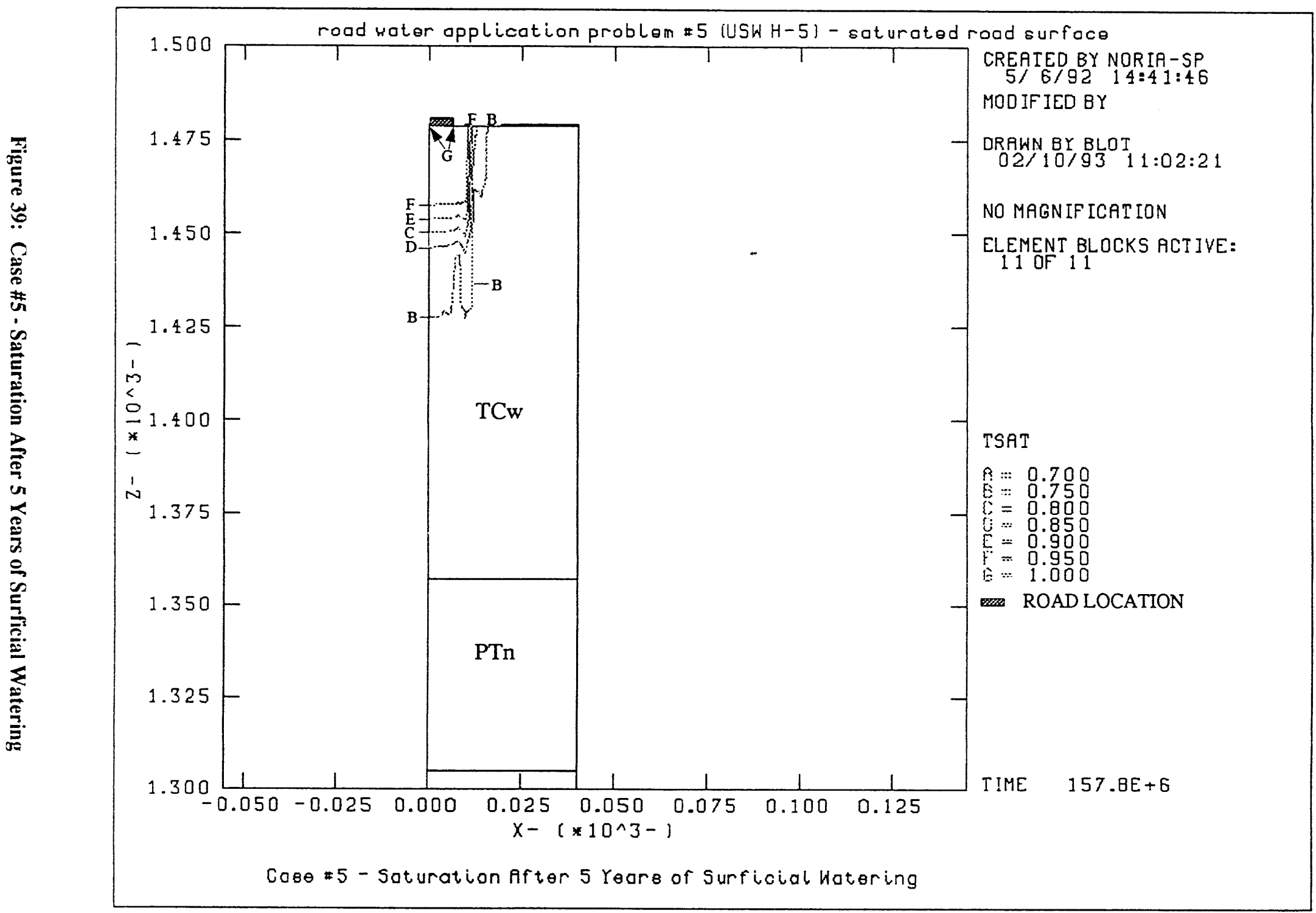




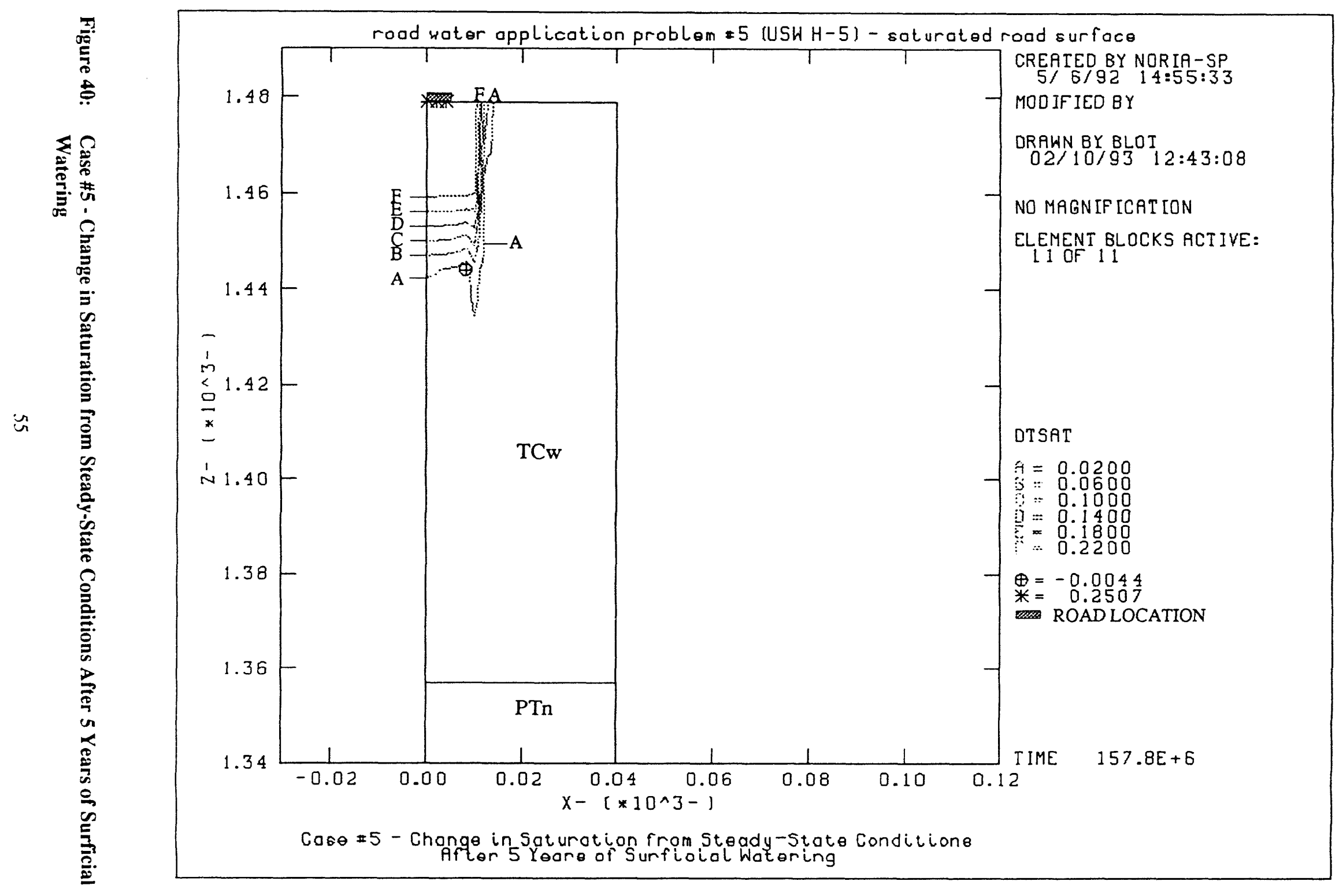




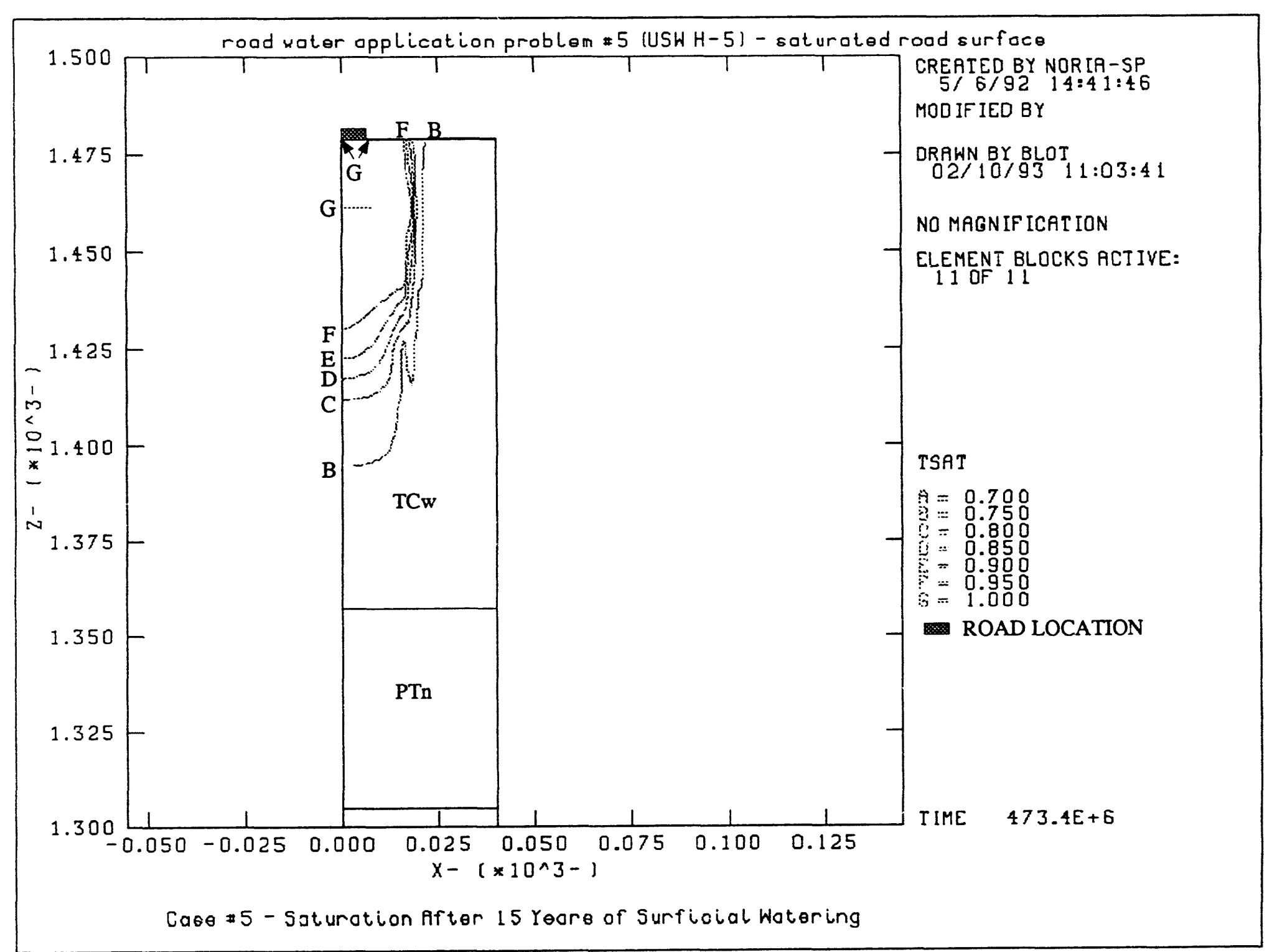




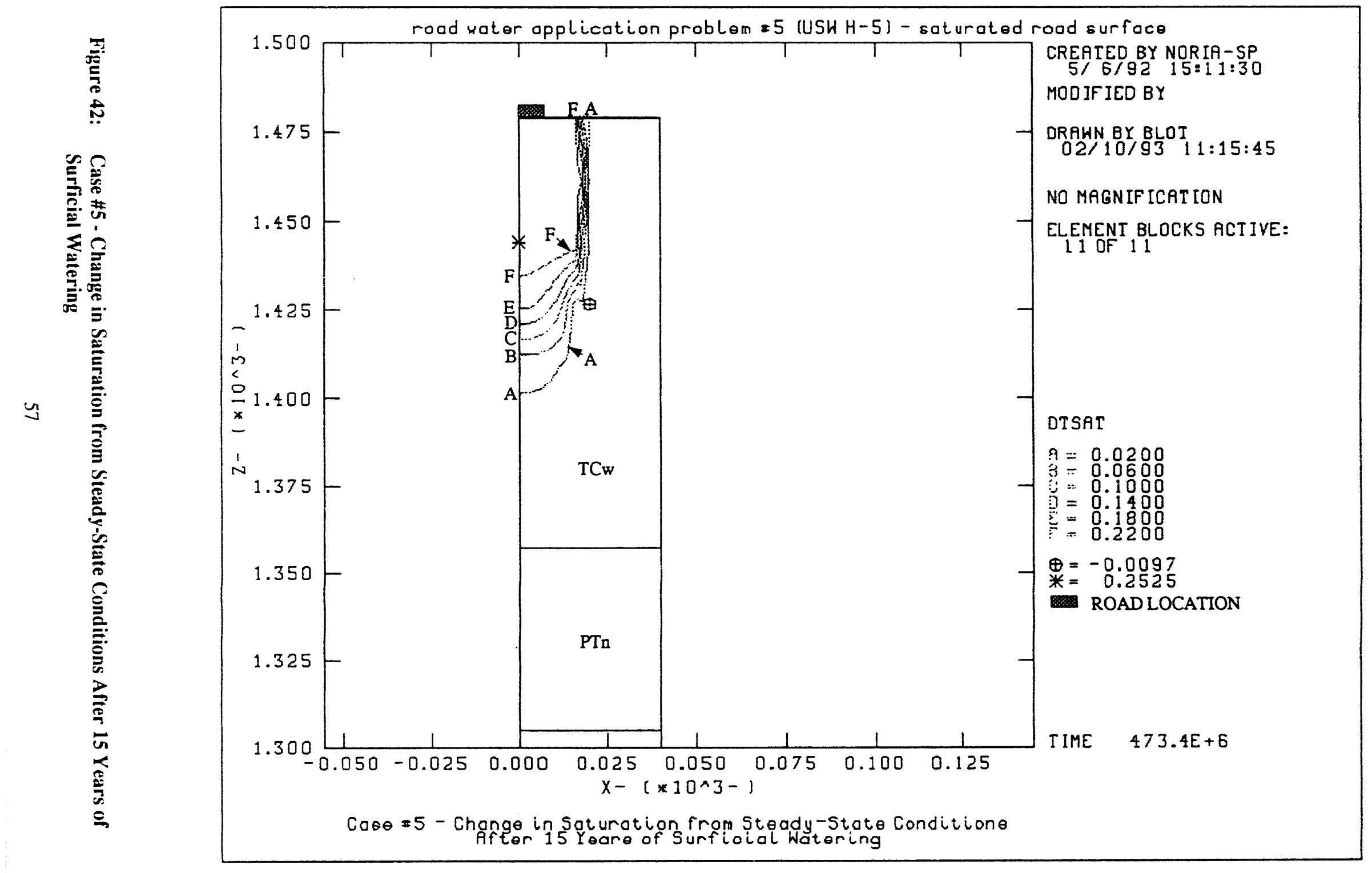




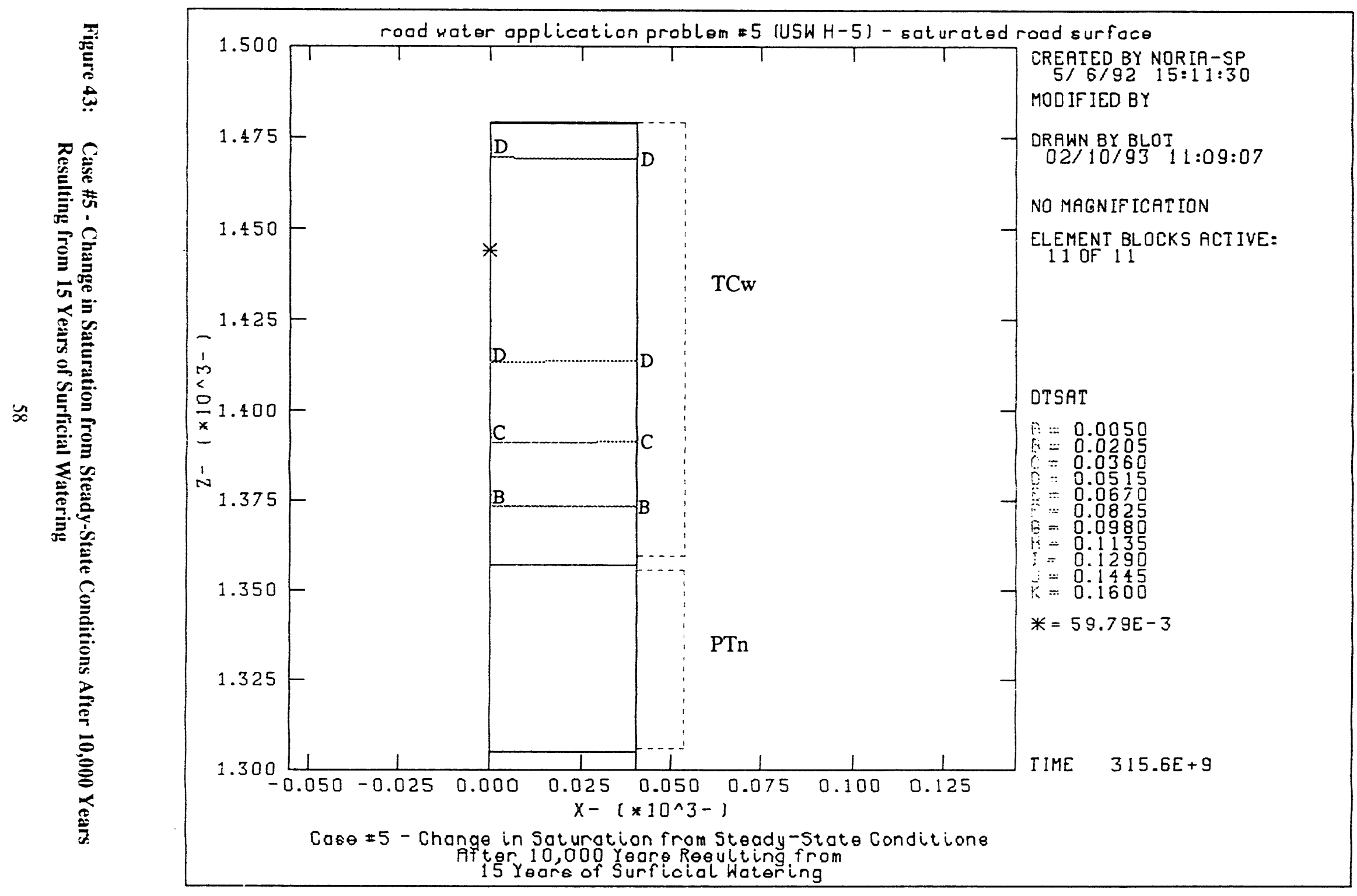




\subsection{Case \#6: Water Movement Near USW H-5 Using a Stratigraphic Model with Natural Gradient}

The preliminary design of the potential repository at Yucca Mountain has the repository dipping so that it is approximately parallel to the dip of the stratigraphic layers. Therefore, the current coordinates of the floor of the repository horizon were obtained, and the westernmost and easternmost points closest to a west-east line through USW H-5 were used as the endpoints of the dip line. This line has a dip angle of $3.47^{\circ}$ from west to east. This angle was used for the dip angle of the stratigraphy.

All stratigraphic layers for Case $\# 6$ were assumed to be parallel and to dip $3.47^{\circ}$. The one exception to this is that the water table was maintained at a constant $775 \mathrm{~m}$ elevation across the computational grid. The road for this case has a horizontal width of $12 \mathrm{~m}$ (an actual width of $12.022 \mathrm{~m}$ ), with the center of the road located at the USW H-5 location. Therefore, the USW H-5 stratigraphy goes through the centerline of the road.

From the calculations for Case \#5, the maximum extent of water movement after 15 years of elevated saturation level was estimated to be about $28 \mathrm{~m}$ from the road centerline. This distance was determined by a difference in saturation level from calculated in situ conditions of $0.02 \%$. Because of this, a horizontal distance of $42 \mathrm{~m}$ from the road centerline $(36 \mathrm{~m}$ from the updip edge of the road) was selected for the updip vertical boundary. In anticipation of a much greater lateral dispersion of water in the down dip direction, the down dip vertical boundary was placed at a horizontal distance of $138 \mathrm{~m}$ from the road centerline (132 $\mathrm{m}$ from the down dip edge of the road). Figure 44 displays the computational grid used for Case \#6.

The steady-state solution for saturation for this case was essentially the same as for Case \#5. The stratigraphic grade employed in Case \#6 has some effect on the movement of the surficial water as compared with Case \#5. The saturation and $\Delta$ sat after 5 years of surficial water application are shown in Figures 45 and 46 . The water movement away from the road is essentially symmetrical Two significant differences between Cases \#5 and \#6 are in the amount of water that infiltrated the road and the extent of migration of that water. For Case \#6,1.2 $\mathrm{m}$ of water had infiltrated after 5 years, compared with $0.93 \mathrm{~m}$ for Case \#5. Additionally, the lateral migration of the water is slightly greater for Case \#6. Figure 47 shows $\Delta$ sat in the TCw and PTn after 15 years of surficial water application; the lateral extent of water movement is again essentially symmetrical, indicating no preference for downhill flow. After 15 years of surficial migration, the amount of water infiltration through the road for Case \#6 is $2.9 \mathrm{~m}$, the same as for Case \#5. It is unclear why the amounts of infiltrated water are significantly different after 5 years, yet the same at 15 years. Additionally, the lateral migration of the water for Case \#6 (as indicated by the contour on Figure 47 representing $2 \%$ change in saturation) is slightly more than that for Case \#5 (compare with the same contour on Figure 42), whereas the vertical migration of the water is nearly $20 \mathrm{~m}$ greater for Case \#5 than for Case \#6. The change in saturation from steady-state conditions resulting from 15 years of surficial water application are plotted in Figures 48, 49, and 50 for 25, 1000 , and 10,000 years respectively. The downdip stratigraphy appears to have a slight effect on the water movement after 100 years, until the plume has reached the updip no-flow boundary; then the flow pattern is significantly altered, and it is not clear whether this alteration is caused 
more by the downdip or the boundary.

In general, the calculations for Case \#6 indicate that the natural mean downgrade of Yucca Mountain will have little significant effect on flow in the Tiva Canyon welded unit. The results from Case \#6 indicate that the downdip condition may encourage lateral movement of the water over vertical movement. The model used in Case \#6 did not allow for runoff. The effects of downgrade on the flow in other units were not evaluated in these calculations. 


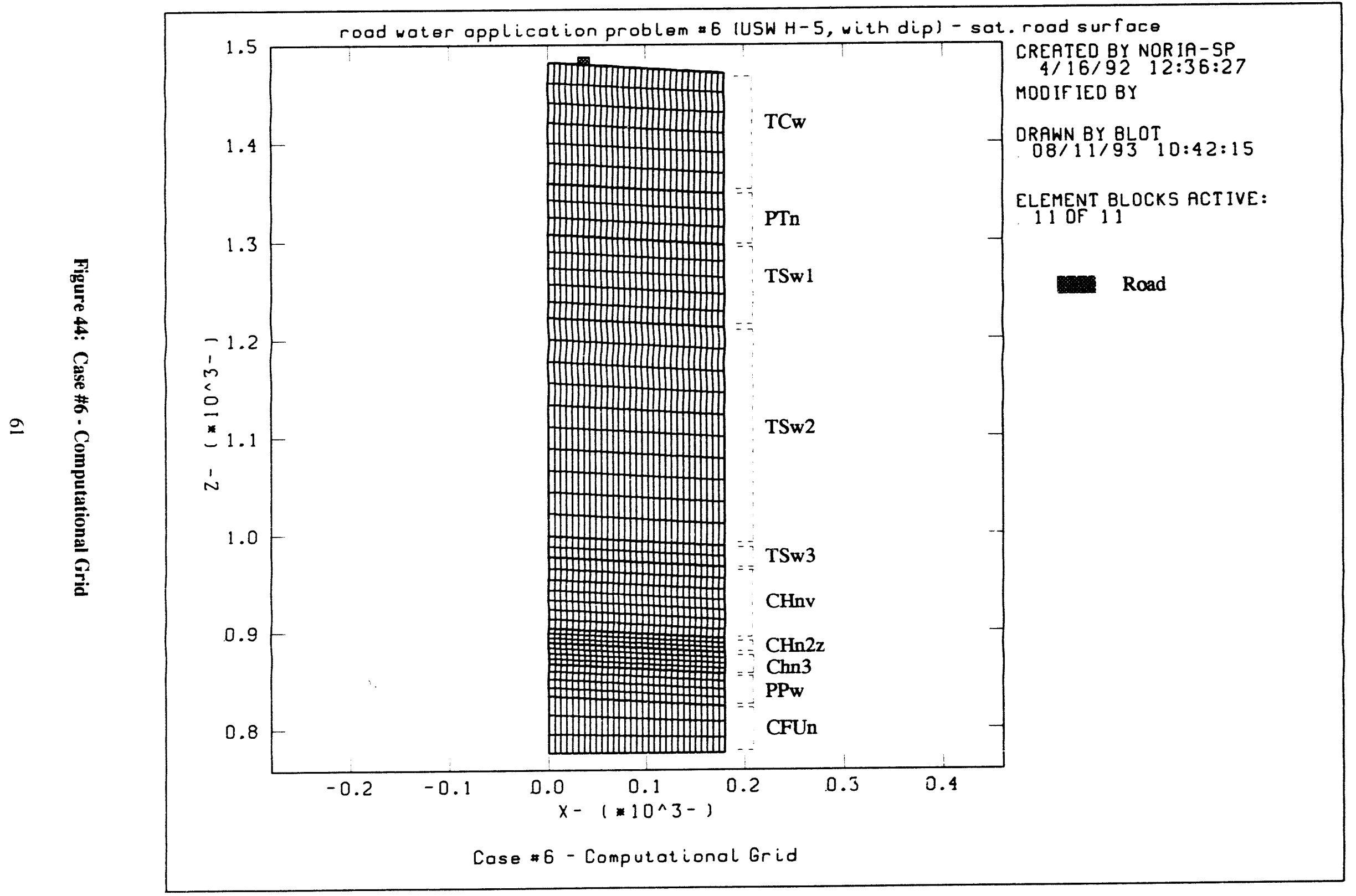




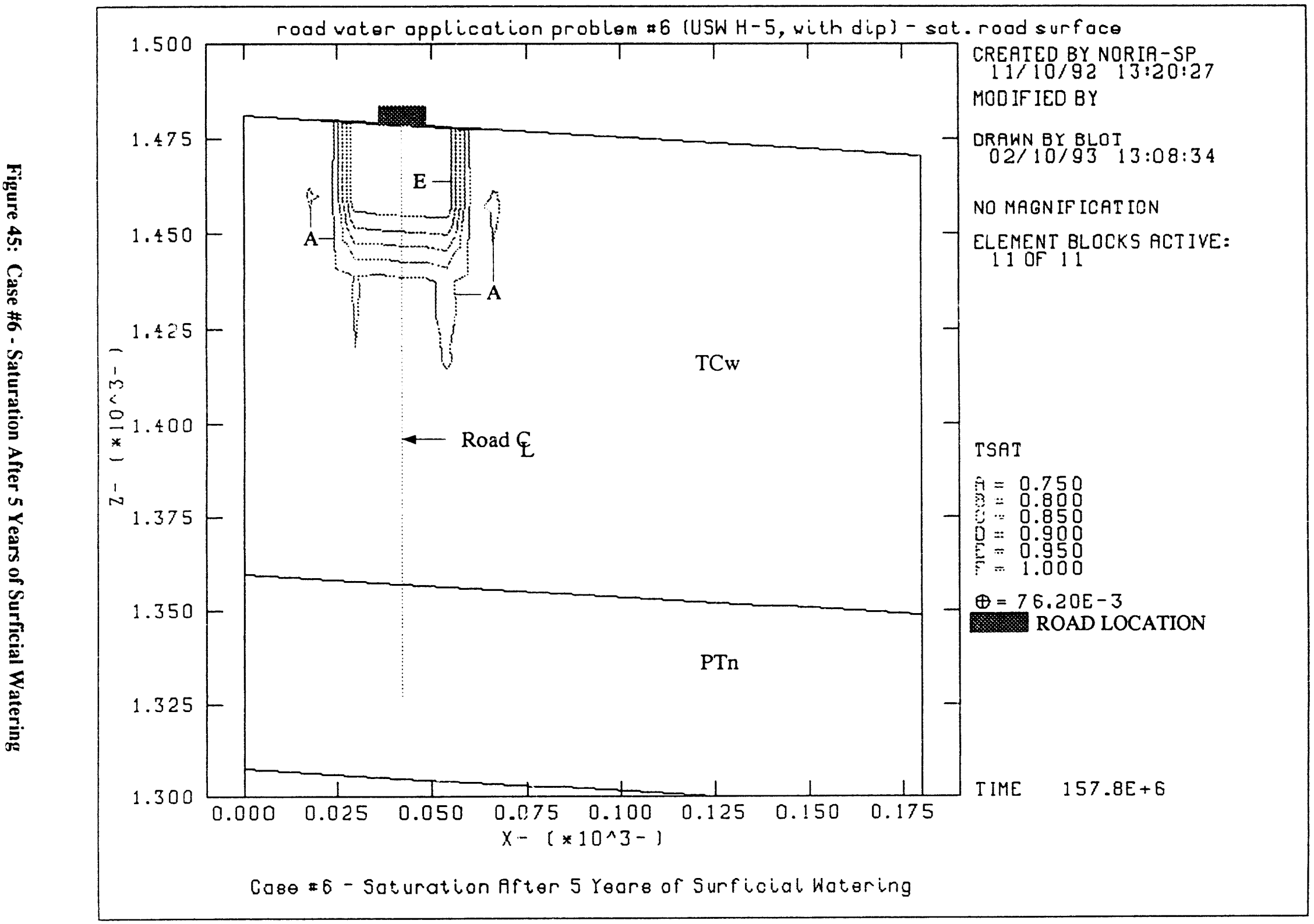




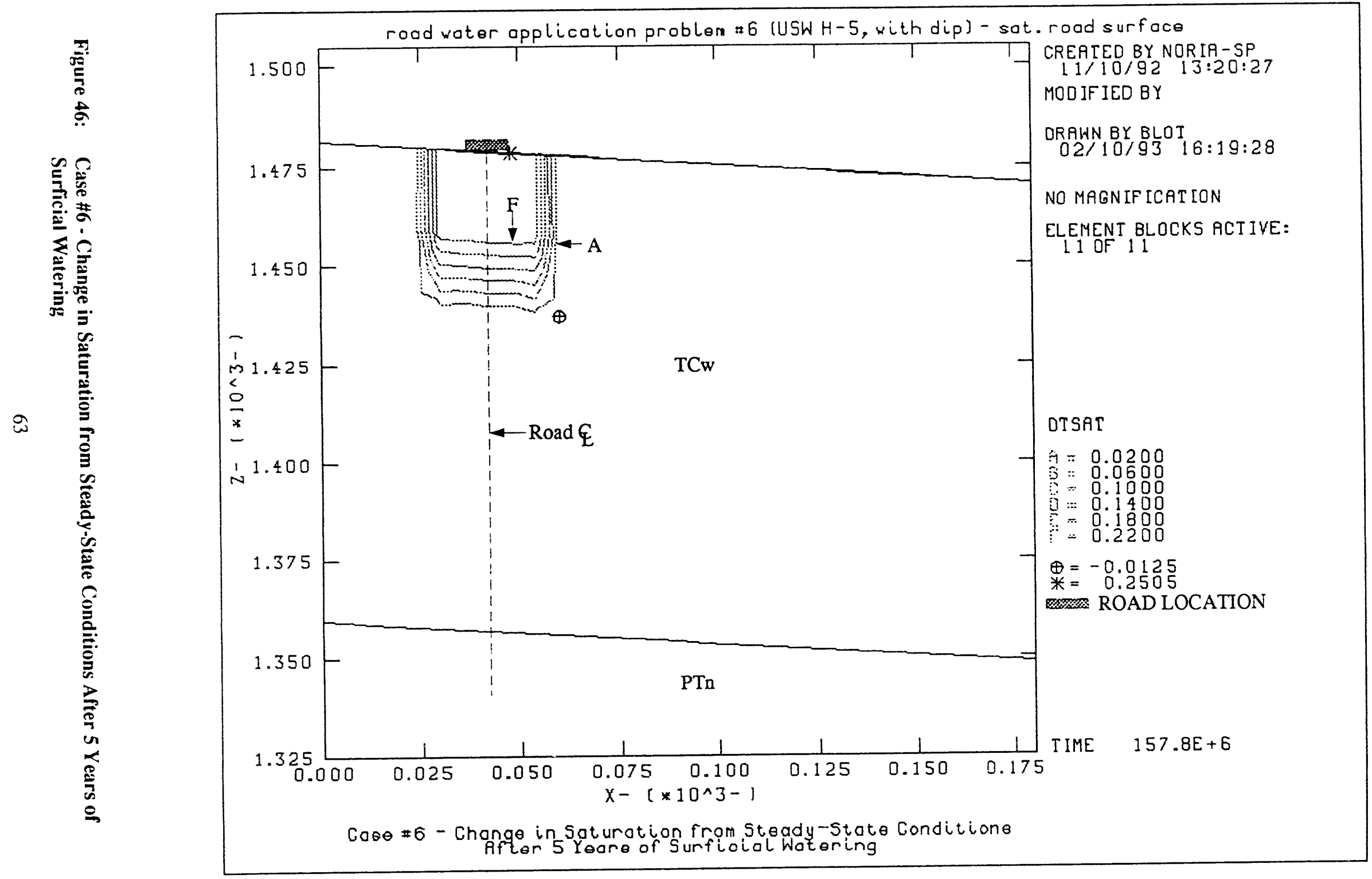




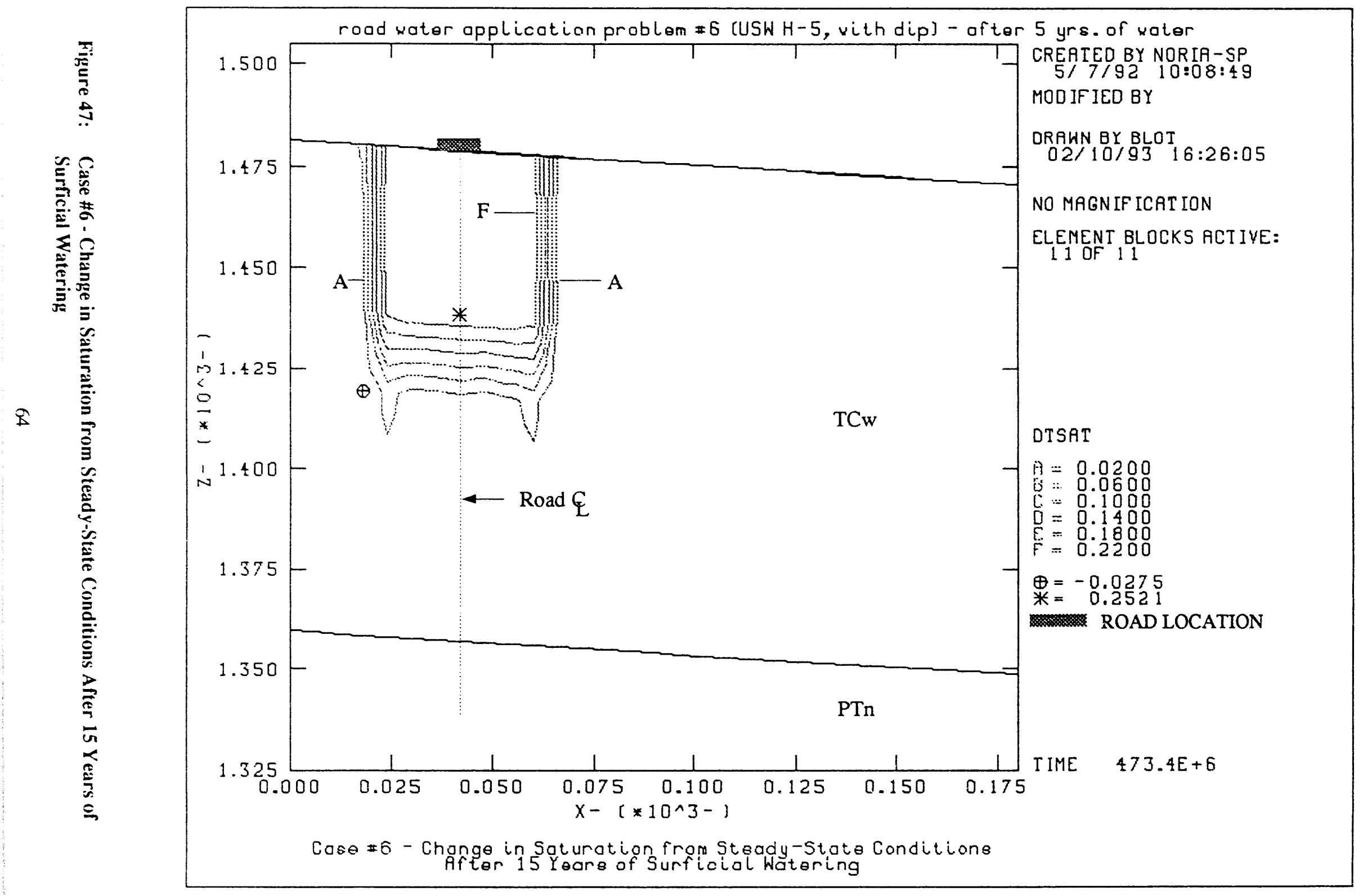




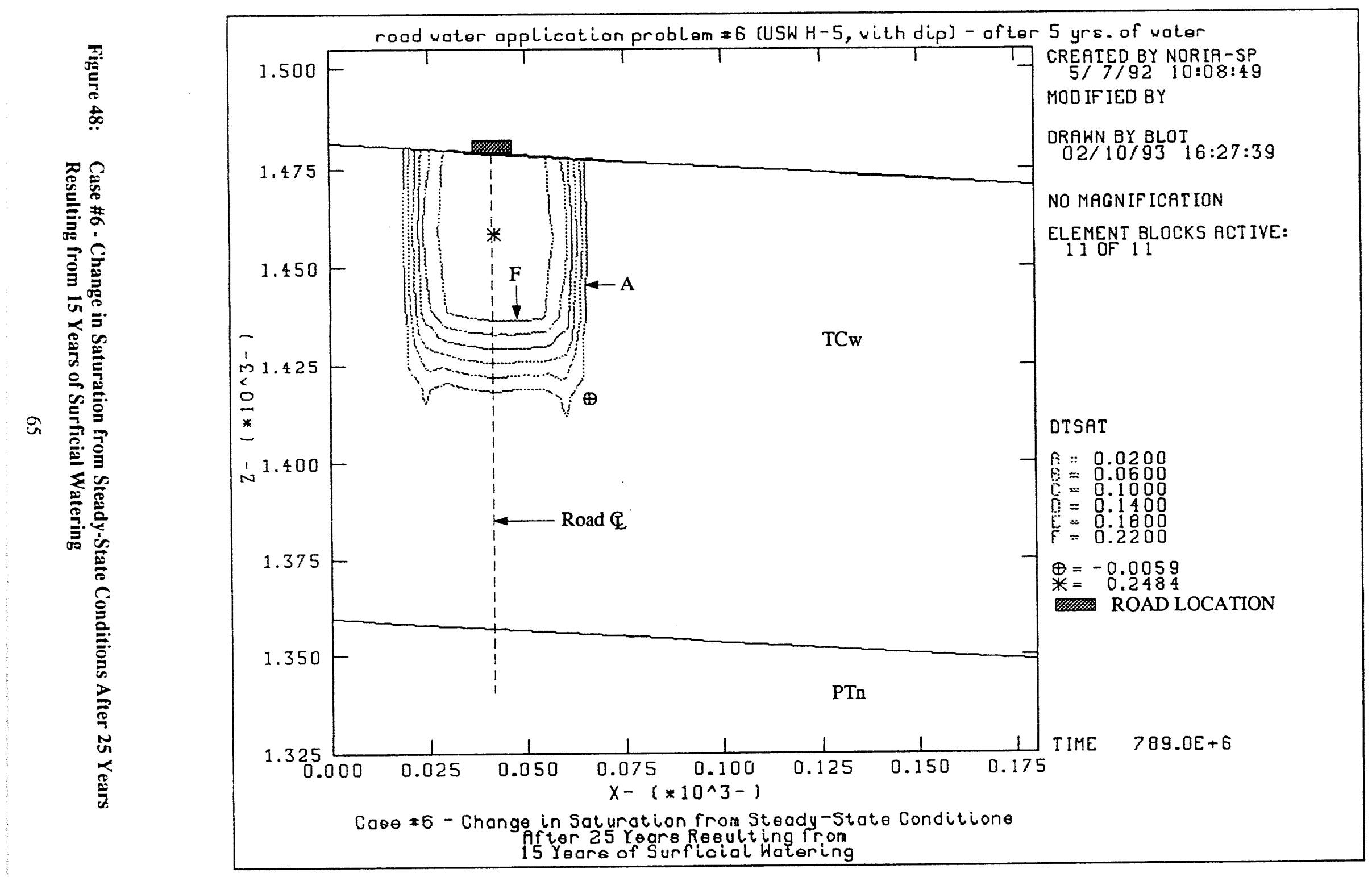




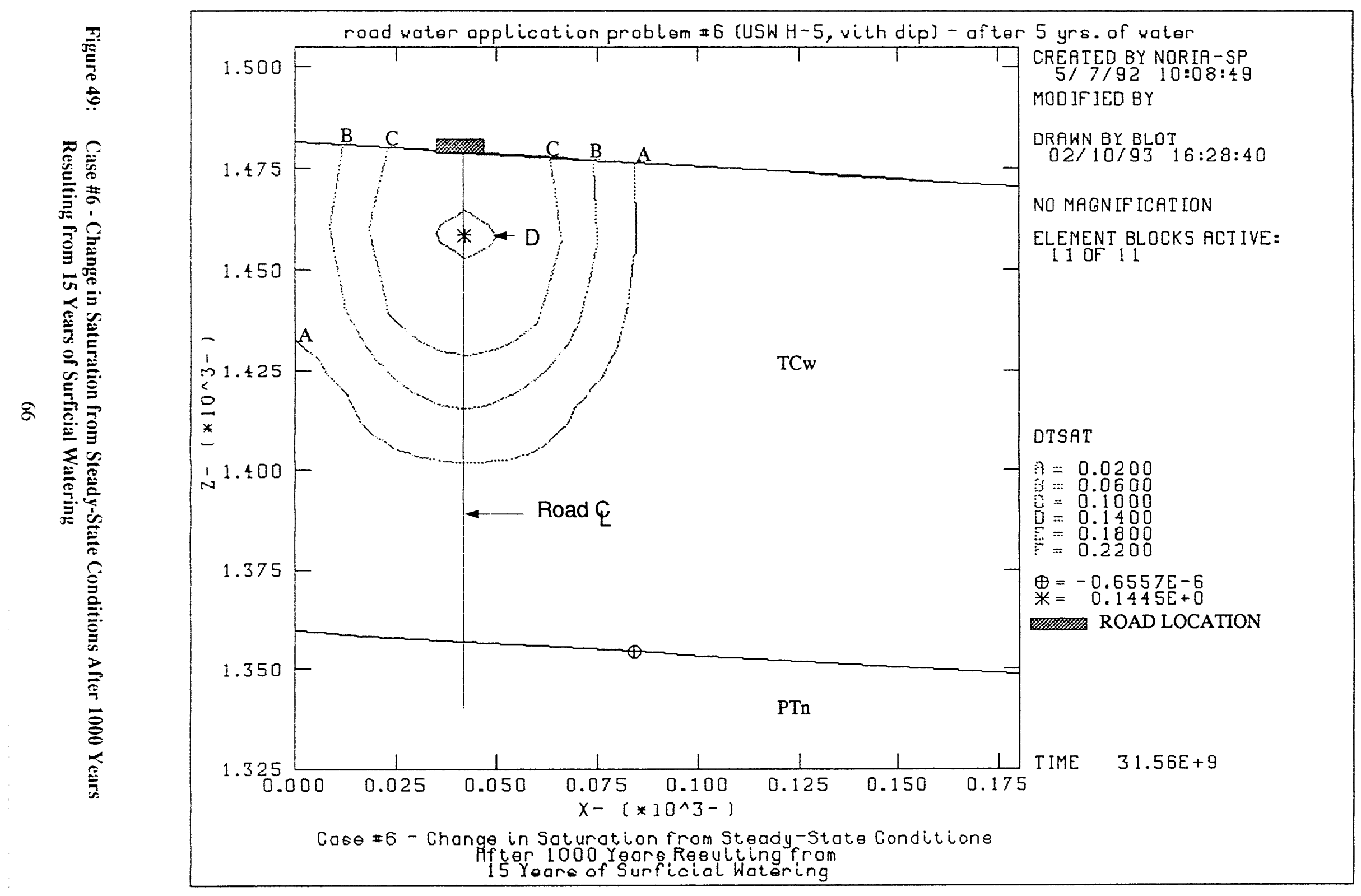




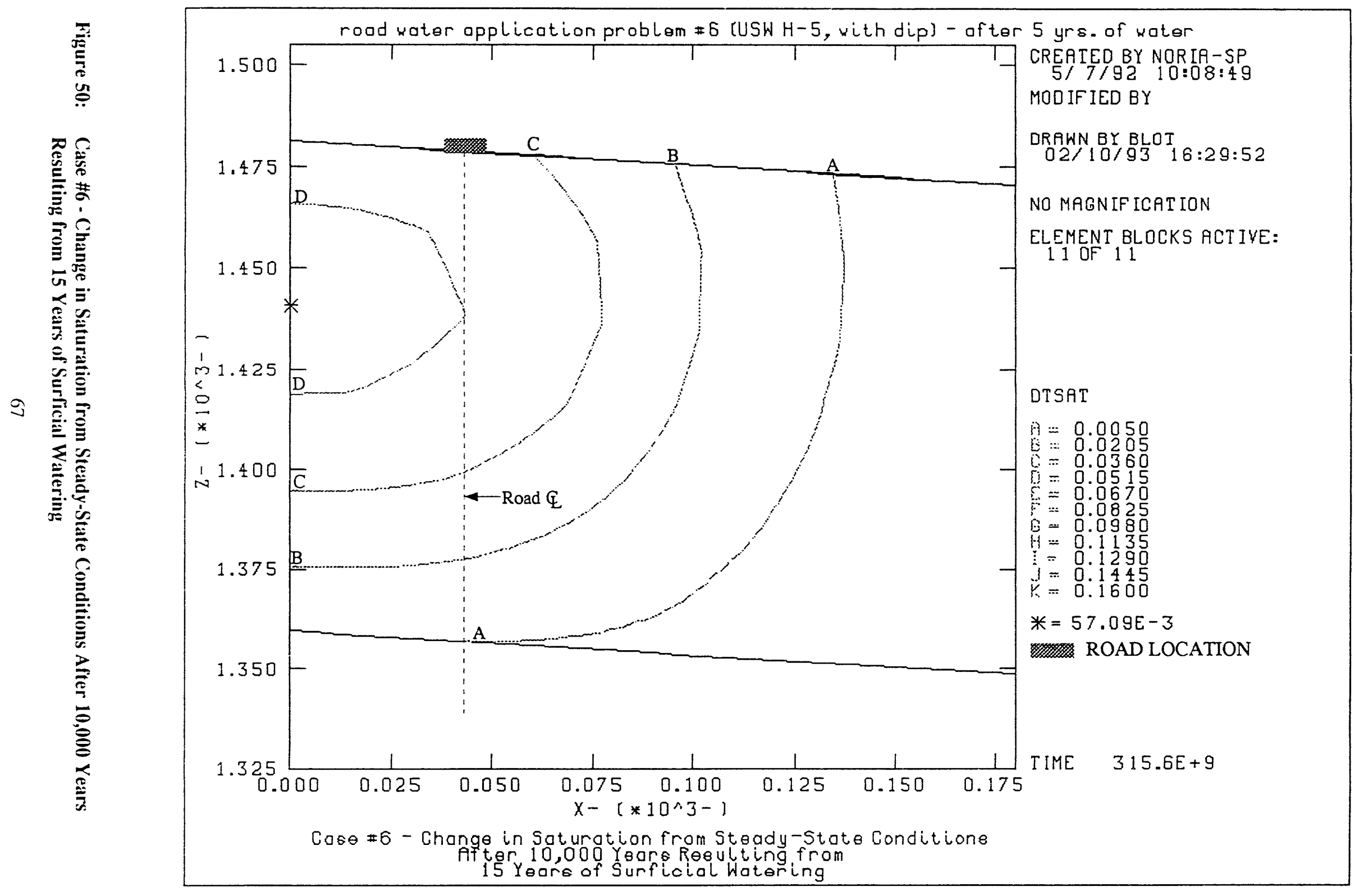




\subsection{Case \#6U: Water Movement Near USW H-5 Considering the Natural Gradient and a}

Thin Alluvium Layer

Cases \#5 and \#6 simulated flow of surficial water at the USW H-5 location, where the surface has a very thin soil layer covering the $\mathrm{TCW}$ bedrock. The effects of natural gradient were evaluated using $\mathrm{TCW}$ as the layer at the top surface. The conclusion drawn from these cases is that the natural mean downdip of Yucca Mountain will have little or no significant effect on flow in the Tiva Canyon welded unit. This conclusions begs the question of what would happen if Case 6 were repeated with an alluvium layer superimposed on top of the in situ stratigraphy. Therefore, the calculations for Case \#6 were repeated with one modification: the addition of an alluvium layer of $1 \mathrm{~m}$ thickness above the USW H-5 stratigraphy. Surficial water was applied for 5 years, after which the surface boundary conditions were returned to the steady-state infiltration rate of $0.01 \mathrm{~mm} / \mathrm{yr}$. All other Case \#6 parameters were unchanged. The steady-state calculations with the added alluvium layer resulted in the same solution for initial saturation in the stratigraphy under the alluvium as was calculated for Case \#6. For convenience, the new calculations for Case \#6 with the additional alluvium layer are referred to as Case \#6U (for Undifferentiated overburden, or alluvium).

In Case \#6, the downdip seemed to have little effect on the lateral movement of the surficial water, as demonstrated in Figure 46 by the symmetry of the region affected by 5 years of surficial water application. The plot of saturation in Figure 51 illustrates the effects of 5 years of surficial water application for Case \#6U. The affected area for Case \#6U is significantly greater than that for Case \#6. There is a slight but clear asymmetry of lateral water movement favoring downhill flow, but the generally symmetric nature of the water migration remains the same. Using the contour representing a $2 \%$ change in saturation in Figure 51 , the extent of water movement on the downhill side of the road is $47.0 \mathrm{~m}$ (or about 7.8 road half-widths) versus $40.8 \mathrm{~m}$ (6.8 roadwidths) on the uphill side of the road. The uphill migration is sufficiently close to the left vertical boundary that it might be restrained in the calculations. Approximately $3.4 \mathrm{~m}$ of water infiltrated through the alluvium road in Case \#6U, nearly 3 times more than for the bedrock road of Case \#6 after 5 years. The change in saturation from steady-state conditions for Case \#6U is plotted in Figures 52 through 54 for 15, 100, and 10,000 years respectively. The downdip appears to have little additional effect on the water movement through 100 years; after that point, the artificial noflow vertical boundary imposed in the calculations affects the lateral movement of the water. This apparent lack of effect on lateral flow may be indicative of the strong suction potential in the TCW relative to the gravitational potential. The strong suction potential in $\mathrm{TCW}$ is also indicated in Figures 53 and 54 by the fact that the water is drained out of the alluvium. Figure 54 indicates that the infiltrated water will remain in the $\mathrm{TCw}$ unit, assuming there are no large fracture or fault networks that provide a fast path to underlying units

Two conclusions may be drawn from the calculations of Cases \#6 and \#6U. First, for preliminary performance assessment purposes, the natural mean downgrade of Yucca Mountain may be assumed to have little significant effect on flow in the Tiva Canyon welded units and in thin layers of alluvium. Second, the presence of a small amount of alluvium or similar soils on the surface can result in significantly greater infiltration and migration of water than on surfaces of lowporosity, welded bedrock 


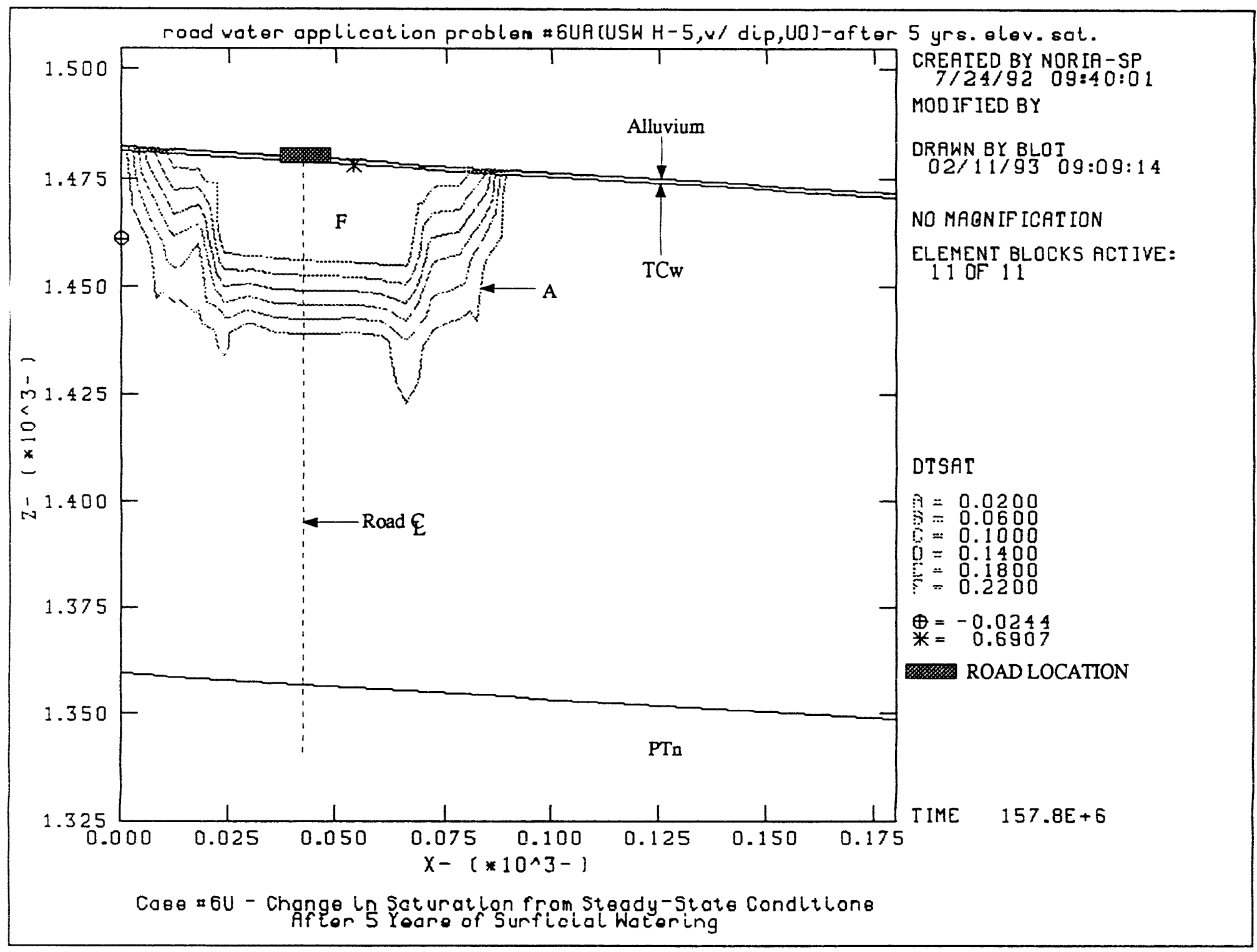




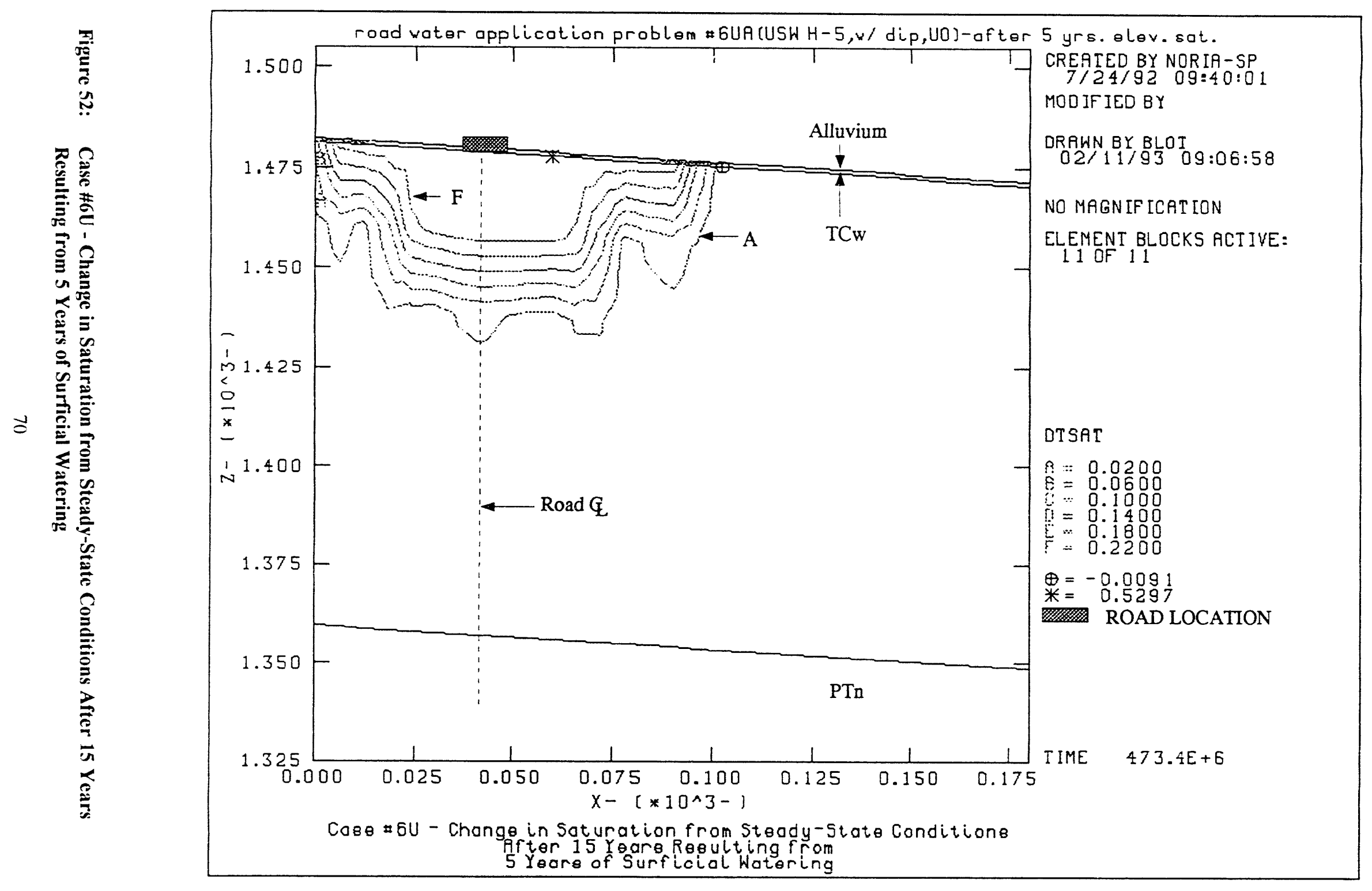




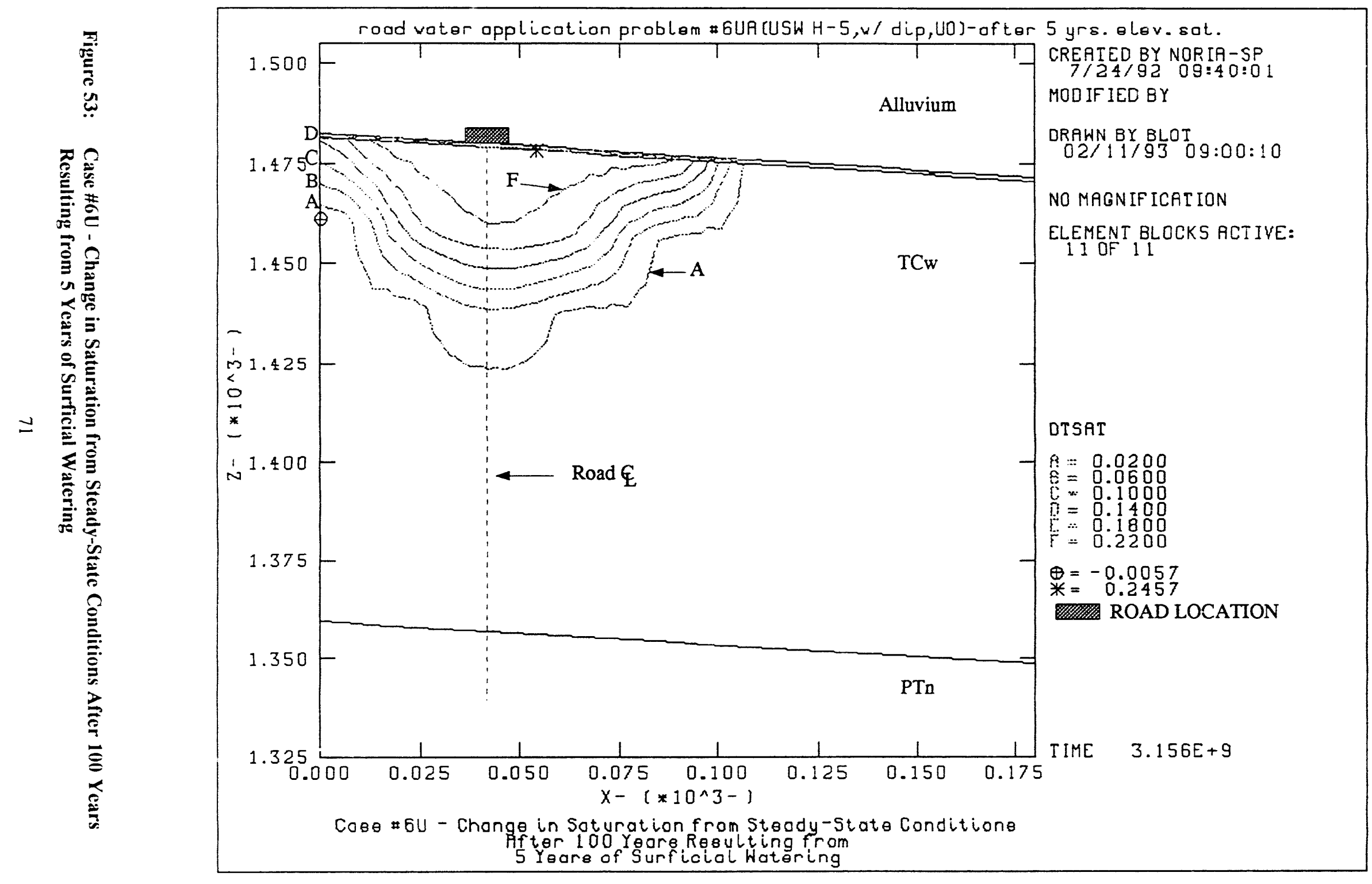




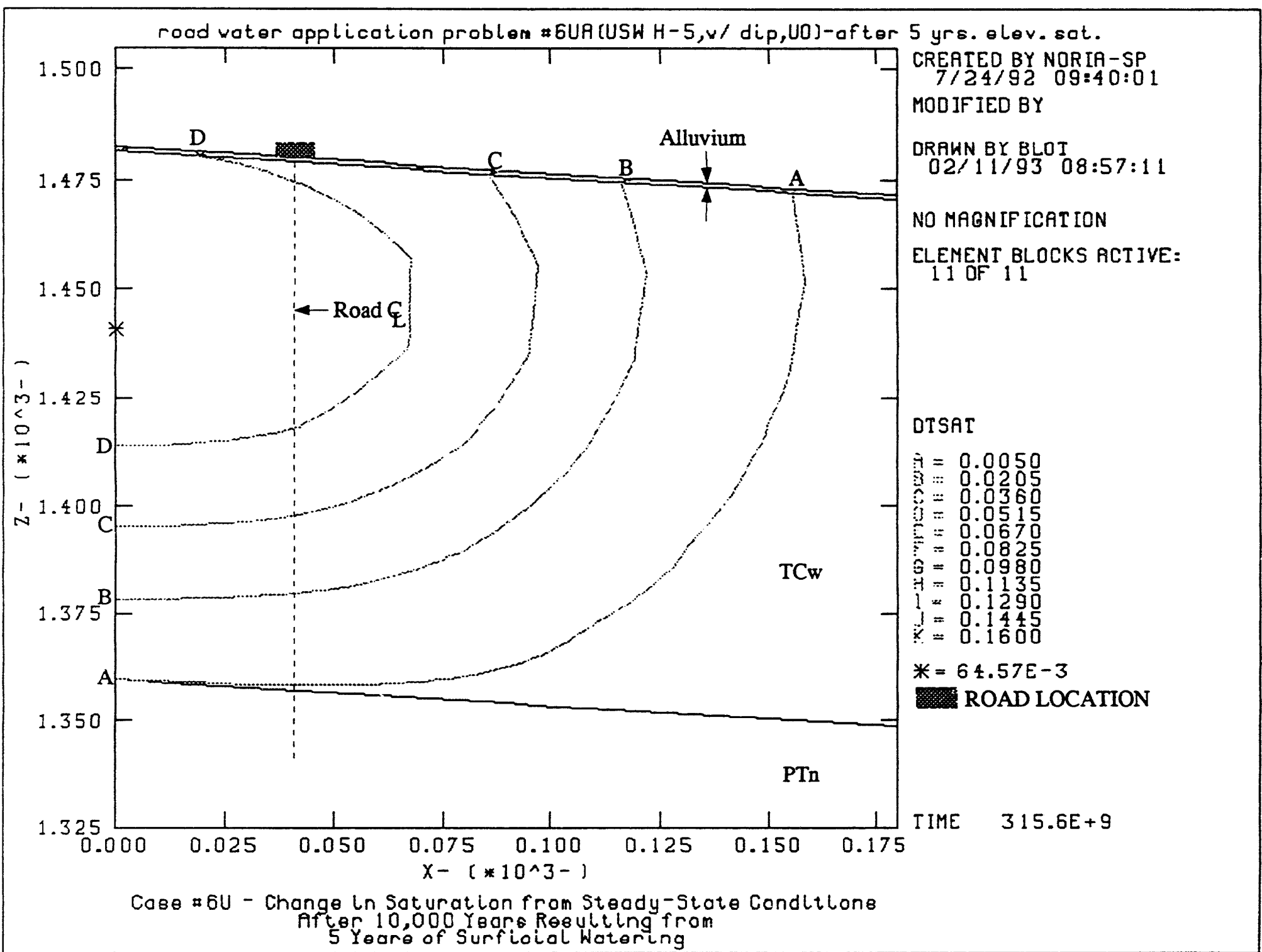




\subsection{IMPLEMENTATION OF THE RESULTS OF THIS ANALYSIS}

Given the results of the six cases described in this report and the limitations and assumptions that are summarized later in this report, the following conclusions have been drawn regarding the use of surficial water outside the Conceptual Drift Perimeter Boundary (CDPB):

1. Surficial water usage outside the CDPB will not affect potential repository performance, given the expected surface conditions and no ponding.

2. Compacted fill material can impede water influx into the alluvium (Cases \#1 and \#2).

3. Alluvium significantly absorbs and spreads surface water (Cases \#1, \#3, and 6U). This has potential effects on tests in neighboring boreholes. This conclusion is especially significant in light of the recent work by the U.S. Geological Survey (USGS) regarding alluvium properties at Pagany Wash (which is discussed later).

4. The natural gradient has little effect on flow in the alluvium and TCw units (Cases \#5, \#6, and \#6U). This conclusion is caveated to the cases and material properties considered, as PTn might act as a capillary barrier under some conditions, and the effects of larger gradients and deeper alluvial deposits have not been evaluated.

An important limitation to the conclusions drawn above is any activity occurring on the western face of Yucca Mountain in Solitario Canyon, where potential fast pathways to the proposed repository horizon exist. Further investigation could be required to determine the potential impact on waste isolation of activities, particularly those involving water or other fluids, in Solitario Canyon. Extra care must be taken for activities occurring at the summit of Yucca Mountain to prevent unintentional runoff down the western slope.

The results of ESF PA Analysis \#12, combined with the previous results of an analysis performed on sewage and settling ponds near the North Portal (Sobolik and Fewell, 1992), can be used as guidance for the location of waste water storage ponds so that they do not affect nearby testing. The same results can also be used as guidance for the location of experiments so they are unaffected by local surficial watering activities such as road watering. The calculations for the sewage pond built on top of alluvium near the North Portal location were integrated with the results of Cases \#1, \#3, \#6, and \#6U from PA Analysis \#12 to obtain the following results. ${ }^{6}$

The analyses cited in the preceding paragraph were formulated similarly. A wetted area was maintained constantly at $100 \%$ saturation for a period of 5 years, after which the steady-state infiltration rate was reimposed. The sewage pond case was calculated using an axisymmetric grid in cylindrical coordinates, whereas the road cases used cartesian coordinates. Also, the pond had a depth of $1.83 \mathrm{~m}$, whereas there was no additional head on the roads; this small difference should not adversely affect a comparison of these results. The results of all the problems are influenced by the different stratigraphies used for each. For all these cases, the problem was modeled with

6 Case \#.5 exhibited results similar to those of Case \#6 with less latera migration, so it was not included in the results described in Section 4.(). 
no evapotranspiration of the additional water; in other words, all the water that infiltrated the ground stayed in the ground. For the road problems, the constant saturation that is used for the boundary condition on the road may result in extremely conservative conclusions and recommendations, as the road watering process is periodic, not continuous, and much evaporation from the road surface occurs between watering applications. The assumption of no evapotranspiration is thought to be conservative for the area around ponds. The resulting recommendations regarding flow around ponds, though, are less conservative than those for roads because the pond area actually could be maintained at constant saturation for the duration of ponding activities; any additional evapotranspiration would occur only at the periphery of the pond.

Table 4 summarizes the results of five years of constant saturation on the wetted surface for the five cases mentioned previously, plus the results of Case \#2, which simulated flow into a road made of compacted fill. The amount of water described in Table 4 is the total volume of infiltrated water divided by the wetted area. Two important observations can be made here. First, the cases for which the alluvium is deeper allow greater amounts of water infiltration. Second, the sewage pond, even though it was simulated with the same stratigraphy as Case \#1, allowed much less areally-averaged water infiltration than Case \#1. This result can be explained by the dimensions of the road, pond, and alluvium. The alluvium for both cases was $9 \mathrm{~m}$ deep. The road width for Case \#1 was $12 \mathrm{~m}$, while the radius of the sewage pond was $54.6 \mathrm{~m}$. Because the pond radius is much larger than the alluvial depth, the general character of the flow of infiltrated water through the pond more closely resembled a one-dimensional flow than that through the road. The underlying Tiva Canyon unit then acted as a barrier to the onedimensional flow because of its significantly lower hydraulic conductivity.

Table 4: Amount of Infiltrated Water for Selected Analytical Cases Evaluating Water Infiltration from Roads and Ponds

\begin{tabular}{|l|c|c|c|}
\hline $\begin{array}{c}\text { Calculational } \\
\text { Case }\end{array}$ & $\begin{array}{c}\text { Surface } \\
\text { Material }\end{array}$ & $\begin{array}{c}\text { Depth of } \\
\text { Alluvium, } \mathrm{m}\end{array}$ & $\begin{array}{c}\text { Areally- Averaged Amount } \\
\text { of Infiltrated Water After 5 } \\
\text { Years (m) }\end{array}$ \\
\hline Case \#1 & Alluvium & 9 & 23.8 \\
\hline Case \#3 & Alluvium & 10 & 27.3 \\
\hline Sewage Pond & Alluvium & 9 & 10.2 \\
\hline Case \#5 & TCw & 0 & 0.93 \\
\hline Case \#6 & TCw & 0 & 1.2 \\
\hline Case \#6U & Alluvium & 1 & 3.4 \\
\hline Case \#2 & $\begin{array}{c}\text { Compacted } \\
\text { road fill }\end{array}$ & N/A & 3.2 \\
\hline
\end{tabular}

The different alluvial depths and surficial dimensions also have an effect on the lateral migration of the water. Table 5 lists for each case the estimated area affected by surficial water based on the distance from the centerline of the road or the center of the pond. This radius is determined by the furthest point from the center of the wetted area where the saturation in either the alluvium or TCw has changed by at 
least $2 \%$. This value for the change in in situ saturation was chosen because it is a typical measurement error for much of the field equipment that could be used to measure saturation in the soil at Yucca Mountain, and because it is well within the variability in measurements that have been taken at Yucca Mountain in the past. The ratio of affected area to wetted area is simple to calculate: for a road, it is the affected radius divided by half the road width; and for a pond, it is the affected radius squared divided by the pond radius squared.

\section{Table 5: Estimations for Size of Wetted Area from NORIA-SP Calculations and from Equation 1}

\begin{tabular}{|l|c|c|c|c|c|}
\hline \multicolumn{1}{|c|}{ Variable } & Case \#1 & Case \#3 & Case \#6 & Case \#6U & Sewage Pond \\
\hline $\begin{array}{l}\text { Depth of } \\
\text { Alluvium (m) }\end{array}$ & 9 & 10 & 0 & 1 & 9 \\
\hline $\begin{array}{l}\text { Shape of wetted } \\
\text { area }\end{array}$ & Road & Road & Road & Road & Circular Pond \\
\hline $\begin{array}{l}\text { Width of road or } \\
\text { radius of pond } \\
\text { (m) }\end{array}$ & 12 & 12 & 12 & 12 & 54.6 \\
\hline $\begin{array}{l}\text { "Radius" affected } \\
\text { by water after 5 } \\
\text { years (m)* }\end{array}$ & 74.7 & 77.8 & 17.3 & 47.0 & 162 \\
\hline $\begin{array}{l}\text { Ratio of affected } \\
\text { area to wetted } \\
\text { area }\end{array}$ & 12.45 & 12.97 & 2.88 & 7.83 & 8.80 \\
\hline \hline $\begin{array}{l}\text { Calculated value } \\
\text { of x as defined in } \\
\text { Equation 1 }\end{array}$ & 1.5 & 1.67 & 0 & 0.167 & 8.72 \\
\hline $\begin{array}{l}\text { Calculated value } \\
\text { of y as defined in } \\
\text { Equation 1 }\end{array}$ & 12.55 & 12.95 & 2.88 & 7.87 & 0.330 \\
\hline
\end{tabular}

* Affected radius is defined by the extent of a minimum change in saturation from the steadystate value by $2 \%$ (e.g., from steady-state value of $74 \%$ saturated to new value of $76 \%$ saturated).

A relationship has been developed (by a curve fit to the calculational results) between the dimensions of the alluvium, the wetted area, and the resulting area affected by surficial water after five years of continuous saturation. The relationship is described as follows: 


$$
\begin{aligned}
y & =\left(4.2+3 e^{-(1-6 x)^{2}}\right) \ln (6 x+1)+2.883, \\
\text { where } x & =\frac{\text { perimeter of wetted surface } * \text { depth of alluvium }}{\text { area of wetted surface }}, \\
\text { and } \quad y & =\frac{\text { area affected by surficial water }}{\text { area of wetted surface }} .
\end{aligned}
$$

For a pond of radius $r$, depth of alluvium $d$, and radius of the affected area $R$,

$$
\mathrm{x}=\frac{2 \pi r d}{\pi r^{2}}=\frac{2 d}{r}, \quad \mathrm{y}=\frac{\pi R^{2}}{\pi r^{2}}=\frac{R^{2}}{r^{2}} ;
$$

for a road of length $l$ and width $w, l>>w$, and $D=$ distance from road centerline affected by the water,

$$
\mathrm{x}=\frac{(2 l+2 w) d}{l w} \approx \frac{2 d}{w}, \mathrm{y}=\frac{2 D l}{w l}=\frac{2 D}{w} .
$$

For the case of a road, its length is much larger than its width, so the value for $\mathrm{x}$ becomes the depth of alluvium divided by half the road width. In addition, for the case of a pond for which the width and length are approximately equal (such as the circular pond; see Sobolik and Fewell, 1992), the minimum value for $y$ should be 4.0. The values for $x$ and the calculated values for $y$ are also included in Table 5 . Equation 1 has also been plotted in Figure 55, along with the valu calculated from the NORIA-SP results for the five cases.

Because evapotranspiration was not considered in the implementation of the results of these calculations, the results posed by Equation 1 are considered to be a conservative assessment of the lateral migration of surficially applied water. Therefore, the recommendation has been made that Equation 1 be included in Appendix I of the ESFDR and in the SBTFRD as a guide for designers to use to determine locations of wastewater storage ponds and surface-based experiments that could be affected by surficial water. For the case of waste water ponds that will be continuously maintained for a long period of time, Equation 1 provides a somewhat conservative guide for pond and experiment location that should be followed strictly until additional analyses incorporating the effects of evapotranspiration are attempted. Because of the periodic nature of road watering, Equation 1 provides a conservative guide for the location of experiments near roads. Because of the potentially higher $h_{y}$ draulic conductivity in alluvium, discussed in Section 6.2 , boreholes should be cased through the alluvium layer to preclude test interference in underlying layers. 


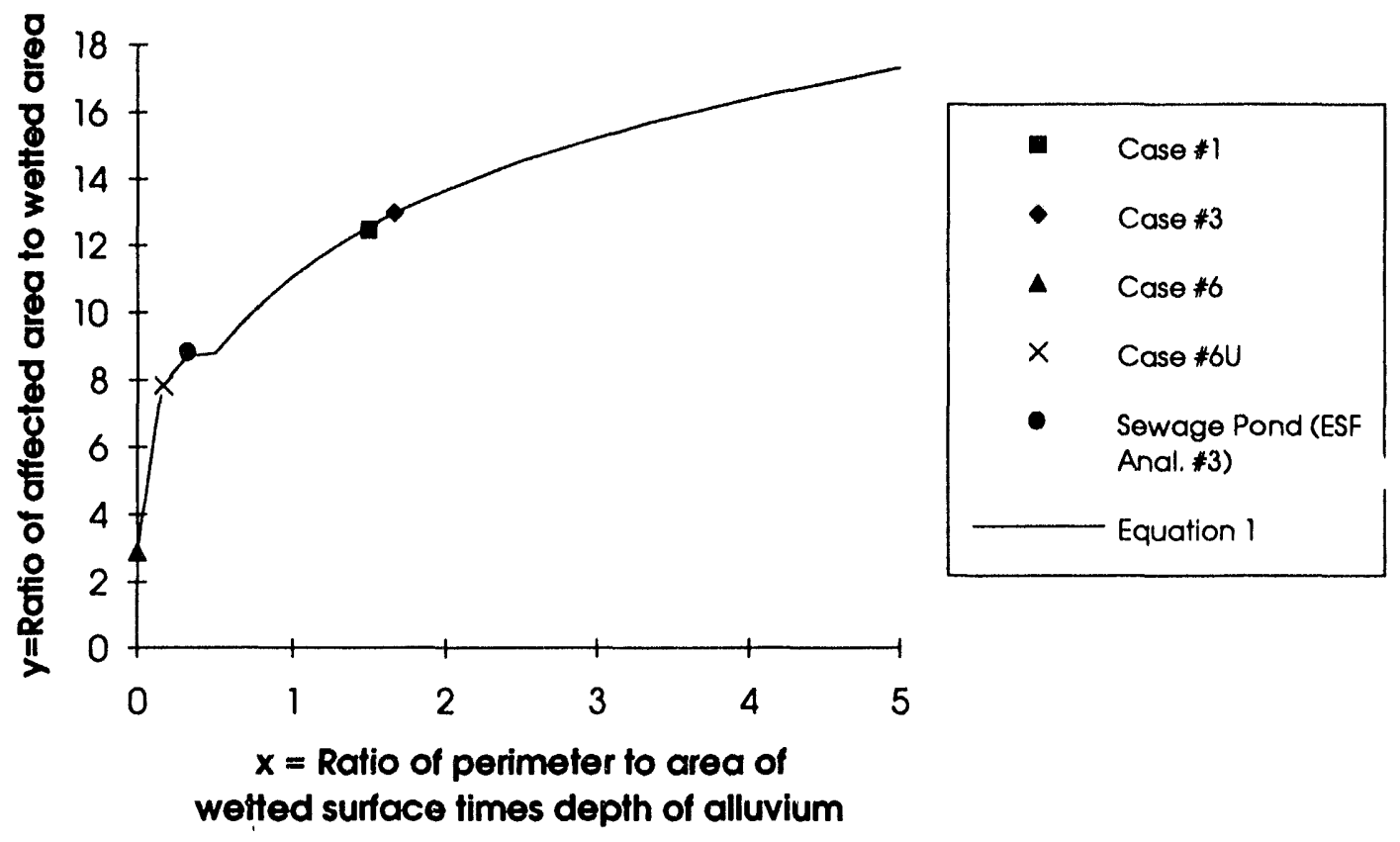

Figure 55: Comparison of NORIA-SP Calculations to Equation 1 Regarding Area Affected by Five Years of Surficial Watering 


\subsection{CONCLUSIONS AND RECOMMENDATIONS}

\subsection{Recommendations for Appendix I of the ESFDR}

The following recommendations have been submitted for inclusion into Appendix I of the ESFDR and the SBTFRD. These recommendations are based on the results of ESF PA Analysis \#12 and other preceding analyses, and they have been made to minimize the potential effects of site characterization activities at Yucca Mountain on waste isolation and test interference.

1. Surficial water applied to alluvium outside the CDPB has no performance assessment impacts given the expected surface conditions (no fracture/fault networks leading directly to the potential repository horizon). For the purposes of preventing potential impacts to waste isolation, surficial water usage outside the CDPB need not be restricted, with the exceptions that runoff and unintentional ponding should be avoided. This recommendation does not apply to activities occurring on the western slope of Yucca Mountain in Solitario Canyon. Surficial water application outside the CDPB should be monitored in accordance with the Tracers, Fluids and Materials Plan.

2. Surficial water applied to alluvium has a high potential for test interference. Accordingly, boreholes in which testing will occur should be cased through the alluvium to preclude test interference in underlying layers.

3. Surficial water applied to alluvium has a high potential for test interference. The placement of surface waste water ponds, and of experiments near such ponds, roads, and other locations where surficial water applications will occur, should be made to preclude test interference. Equation 1 described above should be used by designers as guidance for determining the sizing and/or location of these activities to preclude test interference.

4. Virgin alluvium has a large capacity to store and transport water; this capacity could pose test interference problems. Compacted fill material with a lower storage and transport capacity than alluvium should be used wherever possible for road and pad construction. Bladed and compacted in situ alluvium could be a suitable substitute for virgin alluvium for roads and surface pads. The use of compacted fill material does not invalidate the other three recommendations made under ESF PA Analysis \#12; substantive information regarding the hydraulic properties of the compacted fill would be required before such action may be considered.

\subsection{Other General Recommendations}

The following are more general recommendations that are not required for inclusion in the ESFDR or SBTFRD, but are mentioned here because they are also derived from the results of ESF PA Analysis \#12.

1. Investigate the sensitivity of these and previous analytical results to the potentially varying properties of the alluvium and PTn units.

2. Investigate the hydraulic properties of compacted fill materials to help provide accurate portrayals of road watering scenarios.

3. Investigate infiltration and evapotranspiration phenomena coincident with surficial water addition 


\subsection{LIMITATIONS AND ASSUMPTIONS}

The validity of the results of this analysis depends on the assumptions underlying the conceptual model of flow. This section contains a list of the assumptions and a discussion of the potential errors in the calculations if these assumptions are invalid. Omitted is the fundamental question of the applicability of Darcy's law and Richards' equation -- capillary-bundle theory in general -- to the modeling of unsaturated flow through relatively impermeable rock.

\subsection{Surface Phenomena (Evapotranspiration and Surficial Water Application)}

A potential limitation on the validity of this analysis is the way in which the surface processes are modeled. The ambient ET environment is modeled in this analysis by the time-averaged and areally- averaged infiltration rate of $0.01 \mathrm{~mm} / \mathrm{yr}$. However, the conceptual models for ET processes at Yucca Mountain, both for the usual climatic conditions as well for episodic events such as flooding or surficial watering, are not well developed, and sufficient data do not yet exist to develop these models with confidence. An initial attempt at modeling ET for elevated saturation levels near the surface is documented in this report. In addition, surficial water application is modeled in this analysis as a continuous process, not as an activity that occurs several times a week as would be expected; this may result in an overprediction of the amount of water infiltrating the surface and the range of water movement from the road or wetted surface. A better understanding of surface infiltration processes, including fracture flow at the surface, evapotranspiration, and runoff phenomena, will be required before the uncertainties of water application can be decreased. These new models may require modification of existing flow codes such as NORIA-SP.

The modeling of surface phenomena such as infiltration and runoff and of underground water movement is at some point affected by the manner in which natural grade is assumed in the problem. The $4^{\circ}$ inclination used for Cases \#6 and \#6U seemed to have little effect on the results shown here. An undulating stratigraphy, with slope varying from $0^{\circ}$ to $10^{\circ}$ or more (similar to actual conditions at Yucca Mountain), may provide a more realistic and revealing simulation.

\subsection{MateriaL Hydrological Properties}

The results of the calculations are sensitive to the hydrological properties used for each material. Two materials for which calculations are particularly sensitive are the alluvium and the PTn. The calculations and analyses defined in PDM 72-32 implement a value for the saturated hydraulic conductivity $\left(\mathrm{K}_{\text {sat }}\right)$ of alluvium of $5 \times 10^{-7} \mathrm{~m} / \mathrm{sec}$. This value was obtained in April 1989 from Alan Flint of the USGS. Recently obtained information indicates that more realistic values for $\mathrm{K}_{\text {sat }}$ may be one to two orders of magnitude higher with significant heterogeneity. Alan Flint and Joe Hevesi of the USGS recently analyzed volumetric water content data taken at Pagany Wash following a major flooding event in late 1984. They used an inverse solution method to estimate hydraulic parameters based on standard composition mixtures. Their preliminary results estimate values of $\mathrm{K}_{\text {sat }}$ ranging from $3 \times 10^{-6} \mathrm{~m} / \mathrm{sec}$ to $7 \times 10^{-5} \mathrm{~m} / \mathrm{sec}$. These values indicate that the water storage and flow potential of alluvium may be much greater than what has been shown by this PA analysis. This flow potential is of primary importance to near-surface testing in boreholes, and 
identifies three requirements for performance assessment. One requirement is for more extensive data on the hydraulic properties of alluvium and any potential road fill material. Another is the development of an ET model, both for ambient effects as well as for episodic effects (flooding, road watering, etc.). A third is the development of the capability to model episodic events in codes that model long-term effects (such as NORIA-SP).

It is known that there is a significant qualitative difference in PTn at different locations. PTn is composed of alternating bedded and non-bedded tuffs which are distinct layers at some locations, and are compacted and mixed at others. Data reported for the PTn unit from the RIB and by Weeks and Wilson (1984) suggest that PTn is more saturated than the initial condition given for these calculations. The ambient in situ saturation for PTn is listed in the RIB at $61 \% \pm 15 \%$, and has been reported as high as almost $100 \%$ in some places; the calculations presented here produce a value of near $10 \%$. (Greater initial saturation reduces the amount of space available to store the incoming surface water, and also calls into question the choice of the characteristic curve.) The material hydrologic properties used in the calculations for PTn come from a core sample taken at drill hole USW GU-3, which is located over a kilometer from UE-25a \#1, UE-25 UZ-16, and USW H-5. Rersent measurements taken from samples from the Pah Canyon and Yucca Mountain members of PTn (Flint and Flint, 1990) suggest significantly different values for hydraulic conductivity and moisture retention characteristics. A different porosity value or a different characteristic curve for PTn could significantly change the amount of water that perturbs the saturation at the repository horizon.

\subsection{Homogeneity of Geologic Units}

Geologic units, e.g., the Tiva Canyon welded tuffs, are modeled as a single matrix material and a single fracture material. It is known that hydrologic properties from samples within a geologic unit can vary greatly (Peters et al., 1984). It is unknown what effect this variation would have on flow. For this particular analysis, variations in hydrologic properties in highly conductive and porous regions (such as the surficial alluvium and PTn) may have large effects on the vertical and horizontal dispersion of water. If highly conductive regions are vertically connected, groundwater travel time could be shortened. If highly conductive regions are horizontally connected, lateral dispersion of flow could be enhanced.

Another simplifying assumption used in these calculations is that of isotropic hydraulic conductivity $\left(\mathrm{K}_{\mathrm{xx}}=\mathrm{K}_{z z}\right)$ at each point throughout the geologic units. There is much data in professional hydrologic literature that indicates a higher degree of anisotropy for hydraulic conductivity in soils as the saturation level decreases. This anisotropy in soils tends to favor horizontal movement of water $\left(\mathrm{K}_{\mathrm{x} x /} \mathrm{K}_{z_{2}}>1\right)$. If this sort of anisotropy exists in the alluvium at Yucca Mountain, it could mean that the estimates given in this report for distances of lateral movement of water from roads and ponds may be less conservative than stated. Furthermore, the assumption of isotropic hydraulic conductivity may cause the influence of down dip to be underestimated in the calculations in Cases \#6 and \#6U. However, Flint and Flint (1990) found no evidence of small-scale anisotropy in the nonwelded tuff samples that they tested. 


\subsection{Composite-Porosity Model}

The composite-porosity model used in these calculations treats the matrix and the fractures as an equivalent porous medium. The pressure heads in the matrix and the fractures at any given location are assumed equal. Different flow models have been proposed for Yucca Mountain. For example, the weeps-and-seeps model (Gauthier et al., 1992) assumes that flow is confined to limited regions down connected fracture networks. If the weeps-and-seeps model is applicable to flow at Yucca Mountain, the result would be that a great deal of the surface water could flow directly to the water table within a few years. Such short travel times imply that surface water would not affect the repository: first, the matrix would have little time to saturate, and second, the water would be gone before the repository would be sealed.

\subsection{East Pathways}

Fast pathways such as fractures, faults, and boreholes may either act as preferential pathways that could affect repository performance, or prevent adverse effects by routing water away from the potential repository or acting as a barrier to water flow, depending on their orientation with respect to the proposed repository horizon. Fracture apertures used in these calculations were taken from laboratory measurements (Peters et al., 1984). Actual fractures within Yucca Mountain could have much different apertures. Smaller apertures would tend to favor more flow through the matrix, increasing saturation. Larger apertures would have the opposite effect. Larger apertures could also favor a mechanism of flow different from that modeled by the composite-porosity model. Presence of extremely large apertures (fault zones) could increase the chance of a weeps-and-seeps mechanism that would bypass the water table. 


\subsection{REFERENCES}

Carsel, R. F., and R. S. Parrish, 1988. "Developing Joint Probability Distributions of Soil Water Retention Characteristics," Water Resources Research, Vol. 24, No. 5, May 1988, pp. 755-769. (NNA.910128.0146)

Chow, V. T., Handbook of Applied Hydrology, McGraw-Hill Book Company, 1968. (NNA.900727.0300)

Church, H. W., D. L. Freeman, K. Boro, and R. T. Egami, 1986. Meteorological Tower Data. Yucca Ridge (YR) Site. January-June 1983, SAND85-1053, Sandia National Laboratories, Albuquerque, New Mexico. (NNA.931012.0005)

Church, H. W., D. L. Freeman, K. Boro, and R. T. Egami, 1987. Meteorological Tower Data for the Yucca Alluvial (YA) Site and Yucca Ridge (YR) Site, July, 1983-October, 1984. Final Data Report, SAND86.2533, Sandia National Laboratories, Albuquerque, New Mexico. (NNA.871229.0045)

DOE-YMP, 1992. See U.S. Department of Energy, 1992.

DOE-YMP, 1993. See U.S. Department of Energy, 1993.

Fewell, M. E., S. R. Sobolik, and J. H. Gauthier, 1991. Estimation of the Limitations for Surficial Water Addition Above a Potential High Level Radioactive Waste Repository at Yucca Mountain. Nevada, SAND91-0790, Sandia National Laboratories, Albuquerque, New Mexico. (NNA.911217.0002)

Flint, L. E., and A. L. Flint, 1990. Preliminary Permeability and Water-Retention Data for Nonwelded and Bedded Tuff Samples, Yucca Mountain Area, Nye County, Nevada, USGS/OFR 90-569, U.S. Geological Survey, Denver, Colorado. (NNA.920225.0002)

Gauthier, J. H., M. L. Wilson, and F. C. Lauffer, 1992. "Estimating the Consequences of Significant Fracture Flow at Yucca Mountain," in High Level Radioactive Waste Management: Proceedings of the Third Annual International Conference, American Nuclear Society, La Grange Park, Illinois, pp. 891-898. (NNA.920505.0068)

Hayes, L. R., and T. H. Chaney, 1991. Criteria Letter to C. Gertz, DOE-YMP, dated November 13, 1991, Subject: Criteria Letter for drilling, testing, and instrumenting UE-25 VSP-2 (UZ-16), YMSO, Yucca Mountain, Nevada, YMP-USGS-3343G-()1-C3, R(), U.S. Geological Survey, Denver, Colorado. (NNA.911219.0016)

Hopkins, P. L., N. E. Bixler, and R. R. Eaton, 1991. NORIA-SP - A Finite Element Computer Program for Analyzing Liquid Water Transport in Porous Media, SAND90-2542, Sandia National Laboratories, Albuquerque, New Mexico. (NNA.911202.0031) 
Klavetter, E. A., and R. R. Peters, 1986. Estimation of Hydrologic Properties of an Unsaturated. Fractured Rock Mass, SAND84-2642, Sandia National Laboratories, Albuquerque, New Mexico. (NNA.870317.0738)

Montazer, P., and W. E. Wilson, 1984. Conceptual Hydrologic Model of Flow in the Unsaturated Zone. Yucca Mountain, Nevada, WRIR 84-4345, U.S. Geological Survey, Lakewood, Colorado. (NNA.890327.0051)

Ortiz, T. S., R. L. Williams, F. B. Nimick, B. C. Whittet, and D. L. South, 1985. A ThreeDimensional Model of Reference Thermal/Mechanical and Hydrological Stratigraphy at Yucca Mountain, Southern Nevada, SAND84-1076, Sandia National Laboratories, Albuquerque, New Mexico. (NNA.890315.0013)

Peters, R. R., E. A. Klavetter, I. J. Hall, S. C. Blair, P. R. Heller, and G. W. Gee, 1984. Fracture and Matrix Hydrologic Characteristics of Tuffaceous Materials from Yucca Mountain. Nye County. Nevada, SAND84-1471, Sandia National Laboratories, Albuquerque, New Mexico. (NNA.870407.0036)

Peters, R. R. and E. A. Klavetter, 1988. "A Continuum Model for Water Movement in an Unsaturated Fractured Rock Mass", Water Resources Research, Vol. 24, No. 3, March 1988, pp. 416-430. (NNA.890523.0139)

PDM (Problem Definition Memo), 1992. "ESF PA Analysis \#12 - Estimation of the Extent of Migration of Surficially Applied Water Near the Potential Repository Perimeter," PDM No. 72 32, Sandia National Laboratories, Albuquerque, New Mexico. (NNA.920914.0130)

Robison, J. H., D. M. Stephens, R. R. Luckey, and D. A. Baldwin, 1988. Water Levels in Periodically Measured Wells in the Yucca Mountain Area. Nevada. 1981-87, USGS/OFR 88-468, U.S. Geological Survey, Denver, Colorado. (NNA.891226.0133)

Scott and Castellanos, 1984. Stratigraphic and Structural Relations of Volcanic Rocks in Drill Holes USW GU-3 and USW G-3, Yucca Mountain, Nye County, Nevada, USGS/OFR 84-491, U.S. Geological Survey, Denver, Colorado. (NNA.890804.0017)

Sobolik, S. R., and M. E. Fewell, 1992. Estimation of the Impact of Water Movement from Sewage and Settling Ponds Near a Potential High Level Radioactive Waste Repository in Yucca Mountain. Nevada, SAND91-0792, Sandia National Laboratories, Albuquerque, New Mexico. (NNA.920205.0061)

U.S. Department of Energy, Yucca Mountain Site Characterization Project (DOE-YMP), 1992. Yucca Mountain Site Characterization Project Exploratory Studies Facility Design Requirements Document, Rev. 7/2/92, YMP/CM-0019, Las Vegas, Nevada. (NNA.920903.0087)

U.S. Department of Energy, Yucca Mountain Site Characterization Project (DOE-YMP), 1993. Yucca Mountain Site Characterization Project Surface-Based Testing Facilities Requirements 
Document, Rev. 0, YMP/CM-0022, Las Vegas, Nevada. (NNA.931116.0001)

van Genuchten, M., 1980. "A Closed-Form Equation for Predicting the Hydraulic Conductivity of Unsaturated Soils," Soil Sci. Soc. Am. J., Vol. 44, pp. 892- 898. (NNA.890522.0287)

Weeks, E. P., and W. E. Wilsonı, 1984. Preliminary Evaluation of Hydrologic Properties of Cores of Unsaturated Tuff. Test Well USW H-1, Yucca Mountain, Nevada, WRIR 84-4193, U.S. Geological Survey, Lakewood, Colorado. (NNA.870407.0037) 
APPENDIX A

Parameters Used for the Analyses 
Table A.1. Definition of Input Parameters: Water Properties

\begin{tabular}{lll} 
Description of Variable (units) & Value & Reference \\
\hline Density of water $\left(\mathrm{kg} / \mathrm{m}^{3}\right)$ & 1000 & Standard \\
Compressibility of water $(1 / \mathrm{m})$ & $4.30 \mathrm{E}-06$ & Standard \\
Dyn. Viscosity of water $\left[\mathrm{kg} /\left(\mathrm{m}^{*} \mathrm{sec}\right)\right]$ & 0.001 & Standard @ $68^{\circ} \mathrm{F}$ \\
Acceleration of gravity $\left(\mathrm{m} / \mathrm{sec}^{2}\right)$ & 9.8 & $\begin{array}{l}\text { standard } \\
\text { Steady-state infiltration rate } \mathrm{q}(\mathrm{mm} / \mathrm{yr})\end{array}$ \\
& 0.01 & $\begin{array}{l}\text { Given: Boundary condition } \\
\text { on surface }\end{array}$ \\
$\qquad \mathrm{m} / \mathrm{sec})$ & $3.17 \mathrm{E}-13$ &
\end{tabular}

Table A.2. Definition of Hydrologic Units (Ortiz et al., 1985)

CFUn -- Upper Crater Flat nonwelded, zeolitized unit

$\mathrm{PPw}$-- Prow Pass welded unit

$\mathrm{CHnz}$-- Zeolitized Calico Hills nonwelded unit (CHn3z, CHn2z, CHn 1z)

CHnv -- Vitric Calico Hills nonwelded unit ( $\mathrm{CHn} 3 v, \mathrm{CHn} 2 \mathrm{v}, \mathrm{CHn} 1 \mathrm{v})$

TSw3 -- Basal Vitrophyre of the Topopah Spring welded unit

TSw2 -- Topopah Spring welded unit (The potential repository unit)

TSw1 -- Topopah Spring welded unit

PTn -- Paintbrush nonwelded unit

$\mathrm{TCw}$-- Tiva Canyon welded unit

UO -- Undifferentiated Overburden (alluvium)

\section{STRATIGRAPHIES}

Table A.3. UE-25a \#1 Stratigraphy (stratigraphy from RIB Version 2.002; water table level from Robison et al., 1988); this was used for Cases 1 and 2.

Nevada State Plane Coordinates (feet): E.566,350, N.764,900

\begin{tabular}{lcll} 
Material Designation & Material Number & $\begin{array}{l}\text { Elevation }(\mathrm{m}) \\
\text { Bottom }\end{array}$ & Top \\
\hline Water Table & 1 & 730.6 & 730.6 \\
CHnz & 2 & 798 & 798 \\
TSw3 & 3 & 815 & 815 \\
TSw2 & 4 & 871 & 871 \\
TSw1 & 5 & 1115 & 1115 \\
PTn & 6 & 1140 & 1140 \\
TCw & 7 & 1190 & 1190 \\
UO (Alluvium) & 8 & 1198.9 & 1199 \\
Alluvium Road Layer & & & 1199 \\
(for Case \#1) & 8 & 1198.7 & \\
Compacted Road & & & \\
Material (for Case \#2) & & &
\end{tabular}


Table A.4. UE-25 UZ-16 Expected Stratigraphy (stratigraphy from Hayes and Chaney, 1991; water table level from Robison et al., 1988); this was used for Case \#3.

Nevada State Plane Coordinates (feet): E.564,856.90, N.760,535.32

\begin{tabular}{llll} 
Material Designation & Material Number & $\begin{array}{l}\text { Elevation }(\mathrm{m}) \\
\text { Bottom }\end{array}$ & Top \\
\hline Water Table & 1 & & 730.3 \\
CHn2(z) & 2 & 730.3 & 736 \\
CHn1(v) & 3 & 846 & 847 \\
TSw3 & 4 & 856 & 856 \\
TSw2 & 5 & 1069 & 1069 \\
TSw1 & 6 & 1134 & 1134 \\
PTn & 7 & 1149 & 1149 \\
TCw & 8 & 1210 & 1210 \\
UO (Alluvium) & 9 & 1219.9 & 1220 \\
Road Layer (Alluvium) & & & 1220
\end{tabular}

Table A.5. USW H-5 Stratigraphy (stratigraphy from RIB Version 2.002; water table level from Robison et al., 1988); this was used for Cases \#5, \#6, and \#6U.

Nevada State Plane Coordinates (feet): E.558,909, N.766,634

\begin{tabular}{lclll} 
Material Designation & Material Number & $\begin{array}{l}\text { Elevation }(\mathrm{m}) \\
\text { Bottom }\end{array}$ & Top \\
\hline Water Table & 1 & 775 & 775 & \\
CFUn & 2 & 831 & 831 & \\
PPw & 3 & 864 & 884 & \\
CHn3 & 4 & 886 & 901 & \\
CHn2(z) & 5 & 901 & 906 & Combined \\
CHn2(v) & & 906 & 974 & into one \\
CHn1(v) & & & & unit, CHnv \\
& 6 & 974 & 996 & \\
TSw3 & 7 & 996 & 1220 & \\
TSw2 & 8 & 1220 & 1305 & \\
TSw1 & 9 & 1305 & 1479 & \\
PTn & 10 & 1357 & 1479 & \\
TCw & 11 & 1478.9 & 1480 \\
Road layer (TCw) & 11 & 1479 & & \\
Alluvium (for special & & & &
\end{tabular}




\section{HYDROGEOLOGIC PROPERTIES}

Table A.6. USW G-4 Stratigraphy and Hydrogeologic Properties

\section{Matrix Properties}

All matrix properties from Peters et al., 1984.

\begin{tabular}{|c|c|c|c|c|c|c|c|}
\hline \multirow[b]{2}{*}{ Unit } & \multirow{2}{*}{\multicolumn{2}{|c|}{$\begin{array}{c}\text { Saturated } \\
\text { Hydraulic } \\
\text { Conductivity } \\
(\mathrm{m} / \mathrm{s})\end{array}$}} & \multirow{2}{*}{$\begin{array}{l}\text { Residual } \\
\text { Saturation }\end{array}$} & \multirow{2}{*}{$\begin{array}{c}\alpha \\
(1 / \mathrm{m})\end{array}$} & \multicolumn{3}{|c|}{$\begin{array}{c}\text { Bulk-Rock } \\
\text { Compressibility }\end{array}$} \\
\hline & & & & & B & $(1 / \mathrm{m})$ & Sample \\
\hline CFUn & 0.29 & $2.00 \times 10^{-11}$ & 0.135 & 0.00316 & 2.019 & $2.60 \times 10^{-6 a}$ & G4-19 \\
\hline PPw & 0.24 & $4.50 \times 10^{-9}$ & 0.066 & 0.0141 & 2.639 & $1.70 \times 10^{-6}$ & G4-18 \\
\hline CHnz & 0.28 & $2.00 \times 10^{-11}$ & 0.11 & 0.00308 & 1.602 & $2.60 \times 10^{-6}$ & G4-11 \\
\hline CHnv & 0.46 & $2.70 \times 10^{-7}$ & 0.041 & 0.0160 & 3.872 & $3.90 \times 10^{-6}$ & GU3-14 \\
\hline TSw3 & 0.07 & $1.50 \times 10^{-12}$ & 0.08 & 0.00441 & 2.058 & $5.80 \times 10^{-7}$ & GU3-11 \\
\hline TSw2 & 0.11 & $1.90 \times 10^{-11}$ & 0.08 & 0.00567 & 1.798 & $5.80 \times 10^{-7}$ & G4-6 \\
\hline TSw1 & 0.11 & $1.90 \times 10^{-11}$ & 0.08 & 0.00567 & 1.798 & $1.20 \times 10^{-6}$ & G4-6 \\
\hline PTn & 0.40 & $3.90 \times 10^{-7}$ & 0.10 & 0.015 & 6.872 & $8.20 \times 10^{-6}$ & GU3-7 \\
\hline $\mathrm{TCw}$ & 0.08 & $9.70 \times 10^{-12}$ & 0.002 & 0.00821 & 1.558 & $6.20 \times 10^{-7}$ & G4-1 \\
\hline
\end{tabular}

Fracture Properties

All fracture properties from Klavetter and Peters, 1986.

\begin{tabular}{|c|c|c|c|c|c|c|c|}
\hline Unit & Porosity & $\begin{array}{c}\text { Saturated } \\
\text { Hydraulic } \\
\text { Conductivity } \\
(\mathrm{m} / \mathrm{s})\end{array}$ & $\begin{array}{c}\text { Residual } \\
\text { Saturation }\end{array}$ & $\begin{array}{c}\alpha \\
(1 / \mathrm{m})\end{array}$ & $B$ & $\begin{array}{c}\text { Fracture } \\
\text { Compress- } \\
\text { ibility }(1 / \mathrm{m})\end{array}$ & Sample \\
\hline CFUn & $4.60 \times 10^{-5}$ & $2.00 \times 10^{-4}$ & 0.0395 & 1.2851 & 4.23 & $2.80 \times 10^{-8}$ & $\overline{G 4-4 F^{a}}$ \\
\hline PPw & $1.30 \times 10^{-5}$ & $1.40 \times 10^{-5}$ & 0.0395 & 1.2851 & 4.23 & $0.50 \times 10^{-8}$ & G4-2F \\
\hline $\mathrm{CHnz}$ & $4.60 \times 10^{-5}$ & $2.00 \times 10^{-4}$ & 0.0395 & 1.2851 & 4.23 & $2.80 \times 10^{-8}$ & G4-4F \\
\hline CHnv & $4.60 \times 10^{-5}$ & $2.00 \times 10^{-4}$ & 0.0395 & 1.2851 & 4.23 & $2.80 \times 10^{-8}$ & G4-4F \\
\hline TSw3 & $4.30 \times 10^{-5}$ & $1.60 \times 10^{-5}$ & 0.0395 & 1.2851 & 4.23 & $2.10 \times 10^{-8}$ & G4-2F \\
\hline TSw2 & $1.80 \times 10^{-4}$ & $1.75 \times 10^{-5}$ & 0.0395 & 1.2851 & 4.23 & $1.20 \times 10^{-7}$ & G4-2F \\
\hline TSw1 & $4.10 \times 10^{-5}$ & $2.20 \times 10^{-5}$ & 0.0395 & 1.2851 & 4.23 & $5.60 \times 10^{-8}$ & G4-2F \\
\hline PTn & $2.70 \times 10^{-5}$ & $6.10 \times 10^{-4}$ & 0.0395 & 1.2851 & 4.23 & $1.90 \times 10^{-7}$ & G4-3F \\
\hline $\mathrm{TCw}$ & $1.40 \times 10^{-4}$ & $3.80 \times 10^{-5}$ & 0.0395 & 1.2851 & 4.23 & $1.32 \times 10^{-6}$ & G4-2F \\
\hline
\end{tabular}

a Used fracture and bulk-rock values for $\mathrm{CHnz}$, which is also nonwelded and zeolitic. 
Table A.7. Alluvium (UO) Hydrogeologic Properties

Alluvium Matrix Properties
(representative values taken from van Genuchten, 1980, except as cited)

\begin{tabular}{cccccc} 
& Saturated Hydraulic & Residual & $\alpha$ & & $\begin{array}{c}\text { Bulk-Rock } \\
\text { Compressibility } \\
(1 / \mathrm{m})\end{array}$ \\
\hline $0.32^{\mathrm{a}}$ & Conductivity $(\mathrm{m} / \mathrm{s})$ & Saturation & $\begin{array}{c}\alpha \\
(1 / \mathrm{m})\end{array}$ & $\beta$ & 0 \\
Fracture porosity, none & 0 & 0.3 & 0.423 & 2.06 & \\
Fracture compressiblity, $1 / \mathrm{m}$ & 0 & & &
\end{tabular}

a Values derived from a range of values obtained from personal communication with Alan Flint, U.S. Geological Survey, July 19, 1989.

Table A.8. Compacted Road Fill Hydrogeologic Properties

\begin{tabular}{cccccc} 
& $\begin{array}{c}\text { Saturated Hydraulic } \\
\text { Porosity } \\
\text { Conductivity }(\mathrm{m} / \mathrm{s})\end{array}$ & $\begin{array}{c}\text { Residual } \\
\text { Saturation }\end{array}$ & $\begin{array}{c}\alpha \\
(1 / \mathrm{m})\end{array}$ & $\beta$ & $\begin{array}{c}\text { Bulk-Rock } \\
\text { Compressibility } \\
(1 / \mathrm{m})\end{array}$ \\
\hline $0.15^{\mathrm{a}}$ & $5.00 \times 10^{-8 \mathrm{a}}$ & $0.07^{\mathrm{b}}$ & $0.500^{\mathrm{b}}$ & $1.09^{\mathrm{b}}$ & 0 \\
Fracture porosity, none & 0 & & &
\end{tabular}

a Parameters selected by the principal investigator, based in part on road design information supplied by Reynolds Electrical and Engineering Company.

b Parameters based on those for silty clay from Carsel and Parrish, 1988. 


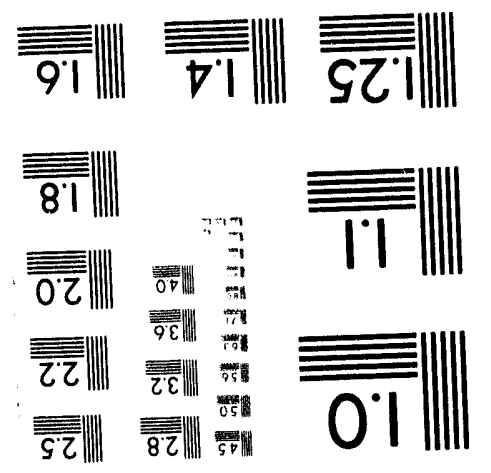


$\mid$
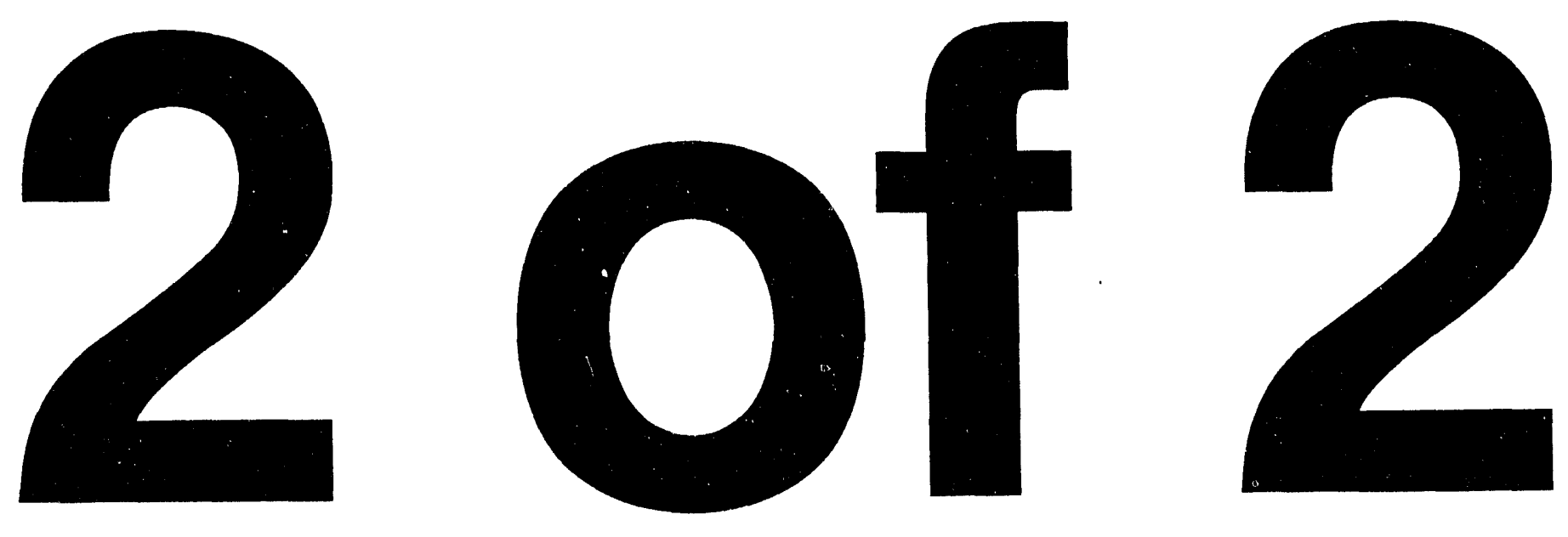


\section{APPENDIX B}

\section{Evapotranspiration Model}

As described in Section 3.1.3, an initial attempt was made to impose an evapotranspiration (ET) model on the non-wetted surface with the assumption that the flux is a function of the local level of saturation. The model is described by the following:

a) For saturation $\mathrm{s}=\mathrm{s}_{\mathrm{in}}$ situ , the flux $\mathrm{q}$ is set to $\mathrm{q}=-0.01 \mathrm{~mm} / \mathrm{yr}\left(-3.17 \times 10^{-13} \mathrm{~m} / \mathrm{sec}\right.$; the negative value indicates infiltration).

b) For saturation $s=100 \%$, the flux $q$ is set equal to the evaporation rate for a small shallow pond (Chow, 1968, as found in Standard Handbook for Civil Engineers, Frederick S. Merritt, editor, p. 21-79, McGraw Hill, New York, 1968.):

$\mathrm{q}=\mathrm{Ex}$,

$\mathrm{E}=\mathrm{C}\left(\mathrm{e}_{\mathrm{w}}-\mathrm{e}_{\mathrm{a}}\right) \Psi$, and

$\Psi=1+0.1 \mathrm{w}$, where

$\mathrm{E}=$ evaporation rate, in inches/30-day month,

$\mathrm{x}=$ conversion factor $=9.8 \times 10^{-9}(\mathrm{~m} / \mathrm{sec}) /(\mathrm{in} . / 30$-day month $)$

$\mathrm{C}$ = an empirical coefficient, equal to 15 for small shallow pools (or 11 for large, deep reservoirs),

$\mathrm{e}_{\mathrm{W}}=$ saturation vapor pressure, in. $\mathrm{Hg}$, corresponding to the monthly mean air temperature observed locally,

$\mathrm{e}_{\mathrm{a}}=$ actual vapor pressure, in. $\mathrm{Hg}$, corresponding to the monthly mean air temperature and relative humidity observed locally,

$\mathrm{w}=$ monthly mean wind velocity, $\mathrm{mph}$ at about $30 \mathrm{ft}$ above ground, and

$\Psi=$ a wind factor

This equation, called the Meyer equation in the referenced text, is predicated on the assumption that the rate of evaporation from a free-water (i.e., saturated) surface is dependent on the vapor pressure gradient between the water surface and the air above it. Measurements of temperature, relative humidity, and wind speed have been taken at Yucca Mountain (Church et al., 1986; Church et al., 1987), and these data were integrated to provide some of the inputs to the Meyer equation. The saturated alluvium was treated as a shallow pond, and thus the value chosen for the coefficient $C$ was 15. In the Standard Handbook for Civil Engineers cited above, an example was given for the evaporation that may occur from a large reservoir: "the mean annual evaporation from Lake Mead is $6 \mathrm{ft}$." The weather data and the resulting monthly evaporation rates used for the calculations in Section 3.1.3 are listed in Table B.1. The $2.7 \mathrm{~m} / \mathrm{yr}$ ET rate predicted for a shallow pond is somewhat higher than the 1.5 to $1.7 \mathrm{~m} / \mathrm{yr}$ currently estimated for in situ conditions from Yucca Mountain. ${ }^{7}$

c) For saturation $s_{\text {in }}$ situ $\leq s \leq 100 \%$, an asymptotic function for flux between the two values

7 Estimate obtained from personal communication with Dwight Hoxie, USGS, August 5, 1993. 
stated in a) and b) is used. The asymptot c function is based on the suction pressure of the alluvial water at the surface.

Table B.1. Yucca Mountain Meteorological Data and the Resulting Monthly Evaporation Rate According to the Meyer Equation

\begin{tabular}{|c|c|c|c|c|c|c|}
\hline & \multicolumn{3}{|c|}{ Monthly Mean Values } & \multirow[b]{2}{*}{$\begin{array}{c}\text { Sat. Vapor } \\
\text { Pressure } \\
\text { in. } \mathrm{Hg} \\
\end{array}$} & \multirow[b]{2}{*}{$\begin{array}{l}\text { Actual Vapor } \\
\text { Pressure } \\
\text { in. } \mathrm{Hg}\end{array}$} & \multirow[b]{2}{*}{$\begin{array}{c}\text { Evap. rate } \\
\mathrm{m} / \mathrm{yr}\end{array}$} \\
\hline & $\begin{array}{l}\text { Temp. } \\
\operatorname{deg} F\end{array}$ & $\begin{array}{l}\text { Relative } \\
\text { Humidity }\end{array}$ & $\begin{array}{c}\text { Wind Vel., } \\
\text { mph }\end{array}$ & & & \\
\hline January & 43.38 & 35.46 & 4.96 & 0.283 & 0.100 & 1.25 \\
\hline February & 42.72 & 31.67 & 6.81 & 0.276 & 0.088 & 1.45 \\
\hline March & 44.29 & 57.92 & 7.34 & 0.293 & 0.170 & 0.98 \\
\hline April & 45.73 & 37.97 & 8.79 & 0.309 & 0.117 & 1.65 \\
\hline May & 63.85 & 16.83 & 7.18 & 0.599 & 0.101 & 3.92 \\
\hline June & 72.58 & 17.57 & 7.2 & 0.810 & 0.142 & 5.25 \\
\hline July & 77.44 & 24.67 & 7.7 & 0.952 & 0.235 & 5.81 \\
\hline August & 74.15 & 51.68 & 5.5 & 0.852 & 0.440 & 2.92 \\
\hline September & 72.48 & 29.06 & 6.19 & 0.807 & 0.234 & 4.24 \\
\hline October & 61.04 & 33.49 & 4.84 & 0.543 & 0.182 & 2.45 \\
\hline November & 47.18 & 34.64 & 6.59 & 0.327 & 0.113 & 1.62 \\
\hline December & 40.59 & 47.54 & 5.06 & 0.254 & 0.121 & 0.92 \\
\hline Annual Mean & & & & & & 2.70 \\
\hline
\end{tabular}




\section{APPENDIX C \\ Reference Information Base and \\ Site Engineering Properties Data Base}

This report uses information from the Reference Information Base; see Appendix A for a listing of the values used.

This report contains no candidate information for inclusion in the Reference Information Base.

This report contains no candidate information for inclusion in the Site and Engineering Properties Data Base. 


\section{YUCCA MOUNTAIN SITE CHARACTERIZATION PROJECT}

\section{DISTRIBUTION LIST}

L. H. Barrett (RW-1)

Assistant Director

OCRWM

US Department of Energy

1000 Independence Avenue SW

Washington, DC 20585

1

J. D. Saltzman (RW-2)

Acting Deputy Director

OCRWM

US Department of Energy

1000 Independence Avenue SW

Washington, DC 20585

1 C. Kouts (RW-4)

Office of Strategic Planning and International Programs

OCRWM

US Department of Energy

1000 Independence Avenue SW

Washington, DC 20585

1 A. Benson (RW-5)

Office of External Relations

OCRWM

US Department of Energy

1000 Independence Avenue SW

Washington, DC 20585

1 Samuel Rousso (RW-10)

Office of Program and Resource Mgt.

OCRWM

US Department of Energy

1000 Independence Avenue SW

Washington, DC 20585

1
J. C. Bresee (RW-10)

OCRWM

US Department of Energy

1000 Independence Avenue SW

Washington, DC 20585
1 L. M. Smith (RW-20)

Ofince of Geologic Disposal

OCRWM

US Department of Energy

1000 Independence Avenue, SW

Washington, DC 20585

1 S. J. Brocoum (RW-22)

Analysis and Verification Division

OCRWM

US Department of Energy

1000 Independence Avenue SW

Washington, DC 2585

1 D. Shelor (RW-30)

Office of Systems and Compliance

OCRWM

US Department of Energy

1000 Independence Avenue, SW

Washington, DC 20585

1 J. Roberts (RW-33)

Director, Regulatory Compliance

Division

OCRWM

US Department of Energy

1000 Independence Avenue, SW

Washington, DC 20585

1 G. J. Parker (RW-332)

OCRWM

US Department of Energy

1000 Independence Avenue, SW

Washington, DC 20585

1 R. A. Milner (RW-40)

Office of Storage and

Transporation

OCRWM

US Department of Energy

1000 Independence Avenue, SW

Washington, DC 20585

Distribution - 1 
S. Rousso (RW-50)

Office of Contract Business

Management

OCRWM

US Department of Energy

1000 Independence Avenue, SW

Washington, DC 20585

1

T. Wood (RW-52)

Director, M\&O Management Division

OCRWM

US Department of Energy

1000 Independence Avenue, SW

Washington, DC 20585

4 Victoria F. Reich, Librarian

Nuclear Waste Technical Review Board

1100 Wilson Blvd, Suite 910

Arlington, VA 22209

5

C. P. Gertz, Project Manager

Yucca Mountain Site

Characterization Project Office

US Department of Energy

P.O. Box 98608--MS 523

Las Vegas, NV 89193-8608

1 C. L. West, Director

Office of External Affairs

DOE Nevada Field Office

US Department of Energy

P.O. Box 98518

Las Vegas, NV 89193-8518

8

Technical Information Officer

DOE Nevada Field Office

US Department of Energy

P.O. Box 98518

Las Vegas, NV 89193-8518

1 P. K. Fitzsimmons, Technical Advisor

Office of Assistant Manager for

Environmental Safety and

Health

DOE Nevada Field Office

US Department of Energy

P.O. Box 98518

Las Vegas, NV 89193-8518
D. R. Elle, Director

Environmental Protection and Division

DOE Nevada Field Office

US Department of Energy

P.O. Box 98518

Las Vegas, NV 89193-8518

1

Repository Licensing \& Quality

Assurance

Project Directorate

Division of Waste Management

US NRC

Washington, DC 20555

1

Senior Project Manager for Yucca

Mountain

Repository Project Branch

Division of Waste Management

US NRC

Washington, DC 20555

1

1

NRC Document Control Desk

Division of Waste Management

US NRC

Washington, DC 20555

Philip S. Justus

NRC Site Representive

301 E Stewart Avenue, Room 203

Las Vegas, NV 89101

$1 \quad$ E. P. Binnall

Field Systems Group Leader

Building 50B/4235

Lawrence Berkeley Laboratory

Berkeley, CA 94720

1 Center for Nuclear Waste

Regulatory Analyses

6220 Culebra Road

Drawer 28510

San Antonio, TX 78284

3

W. L. Clarke

Technical Project Officer - YMP

Attn: YMP/LRC

Lawrence Livermore National

Laboratory

P.O. Box 5514

Livermore, CA 94551 
J. A. Blink

Deputy Project Leader

Lawrence Livermore National

Laboratory

101 Convention Center Drive

Suite 820, MS 527

Las Vegas, NV 89109

4

J. A. Canepa

Technical Project Officer - YMP

N-5, Mail Stop J521

Los Alamos National Laboratory

P.O. Box 1663

Los Alamos, NM 87545

1

H. N. Kalia

Exploratory Shaft Test Manager

Los Alamos National Laboratory

Mail Stop 527

101 Convention Center Dr., \#820

Las Vegas, NV 89101

$1 \quad$ N. Z. Elkins

Deputy Technical Project Officer

Los Alamos National Laboratory

Mail Stop 527

101 Convention Center Dr., \#820

Las Vegas, NV 89101

5

L. E. Shephard

Technical Project Officer - YMP

Sandia National Laboratories

Organization 6302

P.O. Box 5800

Albuquerque, NM 87185

1

J. F. Devine

Asst Director of Engineering Geology

US Geological Survey

106 National Center

12201 Sunrise Valley Drive

Reston, VA 22092

$1 \quad$ L. R. Hayes

Technical Project Officer

Yucca Mountain Project Branch

MS 425

US Geological Survey

P.O. Box 25046

Denver, CO 80225
1

\author{
V. R. Schneider \\ Asst. Chief Hydrologist--MS 414 \\ Office of Program Coordination \\ and Technical Support \\ US Geological Survey \\ 12201 Sunrise Valley Drive \\ Reston, VA 22092
}

1

J. S. Stuckless

Geologic Division Coordinator

MS 913

Yucca Mountain Project

US Geological Survey

P.O. Box 25046

Denver, CO 80225

1 D. H. Appel, Chief

Hydrologic Investigations Program

MS 421

US Geological Survey

P.O. Box 25046

Denver, CO 80225

1 E. J. Helley

Branch of Western Regional Geology

MS 427

US Geological Survey

345 Middlefield Road

Menlo Park, CA 94025

1 R. W. Craig, Chief

Nevada Operations Office

US Geological Survey

101 Convention Center Drive

Suite 860, MS 509

Las Vegas, NV 89109

1

D. Zesiger

US Geological Survey

101 Conventional Center Drive

Suite 860, MS 509

Las Vegas, NV 89109

1 G. L. Ducret, Associate Chief

Yucca Mountain Project Division

US Geological Survey

P.O. Box 25046

421 Federal Center

Denver, CO 80225

Distribution - 3 
1

A. L. Flint

US Geological Survey

MS 721

P.G. Box 327

Mercury, NV 89023

1 D. A. Beck

Water Resources Division, USGS 6770 S Paradise Road

Las Vegas, NV 89119

$1 \quad$ P. A. Glancy

US Geological Survey

Federal Building, Room 224

Carson City, NV 89701

1 J. H. Sass - USGS

Branch of Tectonophysics

2255 N Gemini Drive

Flagstaff, AZ 86001

1 DeWayne Campbell

Technical Project Officer - YMP

US Bureau of Reclamation

Code D-3790

P.O. Box 25007

Denver, CO 80225

1 J. M. LaMonaca

Records Specialist

US Geological Survey

421 Federal Center

P.O. Box 25046

Denver, CO 80225

1 W. R. Keefer - USGS

913 Federal Center

P.O. Box 25046

Denver, CO 80225

1 M. D. Voegele

Technical Project Officer - YMP

SAIC

101 Convention Center Drive

Suite $\mathbf{4 0 7}$

Las Vegas, NV 89109
2

$$
\text { L. D. Foust }
$$

Nevada Site Manager

TRW Environmental Safety

Systems

101 Convention Center Drive

Suite 540, MS 423

Las Vegas, NV 89109

1

C. E. Ezra

YMP Support Office Manager

EG\&G Energy Measurements Inc MS V-02

P.O. Box 1912

Las Vegas, NV 89125

1 E. L. Snow, Program Manager

Roy F. Weston Inc

955 L'Enfant Plaza SW

Washington, DC 20024

1 Technical Information Center

Roy F. Weston Inc

955 L'Enfant Plaza SW

Washington, DC 20024

1 D. Hedges, Vice President, QA

Roy F. Weston Inc

4425 Spring Mountain Road

Suite 300

Las Vegas, NV 89102

1 D. L. Fraser, General Manager

Reynolds Electrical \&

Engineering Co, Inc

MS 555

P.O. Box 98521

Las Vegas, NV 89193-8521

1 B. W. Colston, President and

General Manager

Las Vegas Branch

Raytheon Services Nevada

MS 416

P.O. Box 95487

Las Vegas, NV 89193-5487

$1 \quad$ R. L. Bullock

Technical Project Officer - YMP

Raytheon Services Nevada

Suite P-250, MS 403

101 Convention Center Drive

Las Vegas, NV 89109 
Paul Eslinger, Manager

PASS Program

Pacific Northwest Laboratories

P.O. Box 999

Richland, WA 99352

1 A. T. Tamura

Science and Technology Division

OSTI

US Department of Energy

P.O. Box 62

Oak Ridge, TN 37831

1 Carlos G. Bell Jr

Professor of Civil Engineering

Civil and Mechanical Engineering Dept.

University of Nevada, Las Vegas

4505 S Maryland Parkway

Las Vegas, NV 89154

1 P. J. Weeden, Acting Director

Nuclear Radiation Assessment Div.

US EPA

Environmental Monitoring

Systems Lab

P.O. Box 93478

Las Vegas, NV 89193-3478

$1 \quad$ ONWI Library

Battelle Columbus Laboratory

Office of Nuclear Waste Isolation

505 King Avenue

Columbus, OH 43201

1 T. Hay, Executive Assistant

Office of the Governor

State of Nevada

Capitol Complex

Carson City, NV 89710

3 R. R. Loux

Executive Director

Agency for Nuclear Projects

State of Nevada

Evergreen Center, Suite 252

1802 N. Carson Street

Carson City, NV 89710
1

C. H. Johnson

Technical Program Manager

Agency for Nuclear Projects

State of Nevada

Evergreen Center, Suite 252

1802 N. Carson Street

Carson City, NV 89710

1 John Fordham

Water Resources Center

Desert Research Institute

P.O. Box 60220

Reno, NV 89506

1 David Rhode

Desert Research Institute

P.O. Box 60220

Reno, NV 89506

$1 \quad$ Eric Anderson

Mountain West Research-

Southwest Inc

2901 N Central Avenue \#1000

Phoenix, AZ 85012-2730

1

The Honorable Cyril Schank

Chairman

Churchill County Board of

Commissioners

$190 \mathrm{~W}$ First Street

Fallon, NV 89406

1 Dennis Bechtel, Coordinator

Nuclear Waste Division

Clark County Department of

Comprehensive Planning

301 E Clark Avenue, Suite 570

Las Vegas, NV 89101

1 Juanita D. Hoffman

Nuclear Waste Repository

Oversight Program

Esmeralda County

P.O. Box 490

Goldfield, NV 89013

1

Eureka County Board of Commissioners

Yucca Mountain Information

Office

P.O. Box 714

Eureka, NV 89316

Distribution - 5 
1

Brad Mettam

Inyo County Yucca Mountain

Repository Assessment Office

Drawer L

Independence, CA 93526

$1 \quad$ Lander County Board of

Commissioners

315 South Humbolt

Battle Mountain, NV 89820

1 Vernon E. Poe

Office of Nuclear Projects

Mineral County

P.O. Box 1026

Hawthorne, NV 89415

1 Les W. Bradshaw

Program Manager

Nye County Nuclear Waste

Repository Program

P.O. Box 153

Tonopah, NV 89049

$1 \quad$ Florindo Mariani

White Pine County Nuclear

Waste Project Office

457 Fifth Street

Ely, NV 89301

1 Judy Foremaster

City of Caliente Nuclear Waste

Project Office

P.O. Box 158

Caliente, NV 89008

1 Phillip A. Niedzielski-Eichner

Nye County Nuclear Waste

Repository Project Office

P.O. Box 221274

Chantilly, VA 22022-1274

1 Jason Pitts

Lincoln County Nuclear Waste

Project Office

Lincoln County Courthouse

Pioche, NV 89043
1 Economic Development Dept.

City of Las Vegas

400 E. Stewart Avenue

Las Vegas, NV 89101

1 Commmunity Planning and

Development

City of North Las Vegas

P.O. Box 4086

North Las Vegas, NV 89030

1 Community Development and

Planning

City of Boulder City

P.O. Box 61350

Boulder City, NV 89006

1 Commission of the European

Communities

200 Rue de la Loi

B-1049 Brussells

BELGIUM

6

M. J. Dorsey, Librarian

YMP Research and Study Center

Reynolds Electrical \&

Engineering Co Inc

MS 407

P.O. Box 98521

Las Vegas, NV 89193-8521

1

Amy Anderson

Argonne National Laboratory

Building 362

$9700 \mathrm{~S}$ Cass Avenue

Argonne, IL 60439

1 Steve Bradhurst

P.O. Box 1510

Reno, NV 89505

1 Michael L. Baughman

35 Clark Road

Fiskdale, MA 01518

1 Glenn Van Roekel

Director of Community

Development

City of Caliente

P.O. Box 158

Caliente, NV 89008 
Ray Williams, Jr

P.O. Box 10

Austin, NV 89310

1 Charles Thistlethwaite, AICP

Associate Planner

Inyo County Planning Department

Drawer L

Independence, CA 93526

$1 \quad$ Nye County District Attorney

P.O. Box 593

Tonopah, NV 89049

1 William Offutt

Nye County Manager

Tonopah, NV 89049

1 R. F. Pritchett

Technical Project Officer - YMP

Reynolds Electrical \&

Engineering Company Inc

MS 408

P.O. Box 98521

Las Vegas, NV 89193-8521

1 Dr. Moses Karakouzian

1751 E Reno \#125

Las Vegas, NV 89119

1 Dwight Hoxie

USGS - Las Vegas

YMSCP

101 Convention Center Drive

Mail Stop 509

Las Vegas, NV 89109

1 Dierdre Boak

LANL - Las Vegas

YMSCP

101 Convention Center Drive

Mail Stop 527

Las Vegas, NV 89109

$1 \quad$ Albin Brandstetter

M\&O/Intera - Las Vegas

YMSCP

101 Convention Center Drive

Mail Stop 423

Las Vegas, NV 89109
$16300 \quad$ D.E. Ellis

16302 L.E. Shephard

$1 \quad 6312 \quad$ H.A. Dockery

$1 \quad 6313 \quad$ L.S. Costin

$2 \quad 6352 \quad$ G.M. Gerstner-Miller for 100/12547/SAND92-2248/QA

26352 G.M. Gerstner-Miller for DRMS files

20 $\quad 6352 \quad$ WMT Library

$1 \quad 6319 \quad$ R.R. Richards

16115 P.B. Davies

$1 \quad 1502 \quad$ P.J. Hommert

$16410 \quad$ D.A. Dahlgren

$5 \quad 7141$ Technical Library

17151 Technical Publications

10 7613-2 Document Processing for DOE/OSTI

8523-2 Central Technical Files

$\begin{array}{lll}\mathbf{1} & \mathbf{1 5 1 1} & \text { P.L. Hopkins } \\ \mathbf{1} & \mathbf{1 5 1 1} & \text { M.J. Martinez } \\ \mathbf{1} & \mathbf{1 5 1 3} & \text { R.R. Eaton } \\ \mathbf{1} & \mathbf{6 1 1 5} & \text { C.K. Ho } \\ \mathbf{1} & \mathbf{6 3 0 2} & \text { F.J. Schelling } \\ \mathbf{1} & \mathbf{6 3 1 2} & \text { R.W. Barnard } \\ \mathbf{1} & \mathbf{6 3 1 2} & \text { G.E. Barr } \\ \mathbf{1} & \mathbf{6 3 1 2} & \text { E. Dunn } \\ \mathbf{1} & \mathbf{6 3 1 2} & \text { J.H. Gauthier } \\ \mathbf{1} & \mathbf{6 3 1 2} & \text { W.G. Perkins } \\ \mathbf{1} & \mathbf{6 3 1 2} & \text { T.H. Robey } \\ \mathbf{1} & \mathbf{6 3 1 2} & \text { M.L. Wilson } \\ \mathbf{1} & \mathbf{6 3 1 3} & \text { R.E. Finley } \\ \mathbf{1} & \mathbf{6 3 1 3} & \text { J.E. Grant } \\ \mathbf{1} & \mathbf{6 3 1 3} & \text { J. Pott } \\ \mathbf{1} & \mathbf{6 3 1 3} & \text { E.E. Ryder } \\ \mathbf{5} & \mathbf{6 3 1 3} & \text { S.R. Sobolik } \\ \mathbf{1} & \mathbf{6 3 1 3} & \text { C.F. Taylor } \\ \mathbf{5} & \mathbf{6 3 4 2} & \text { M.E. Fewell }\end{array}$



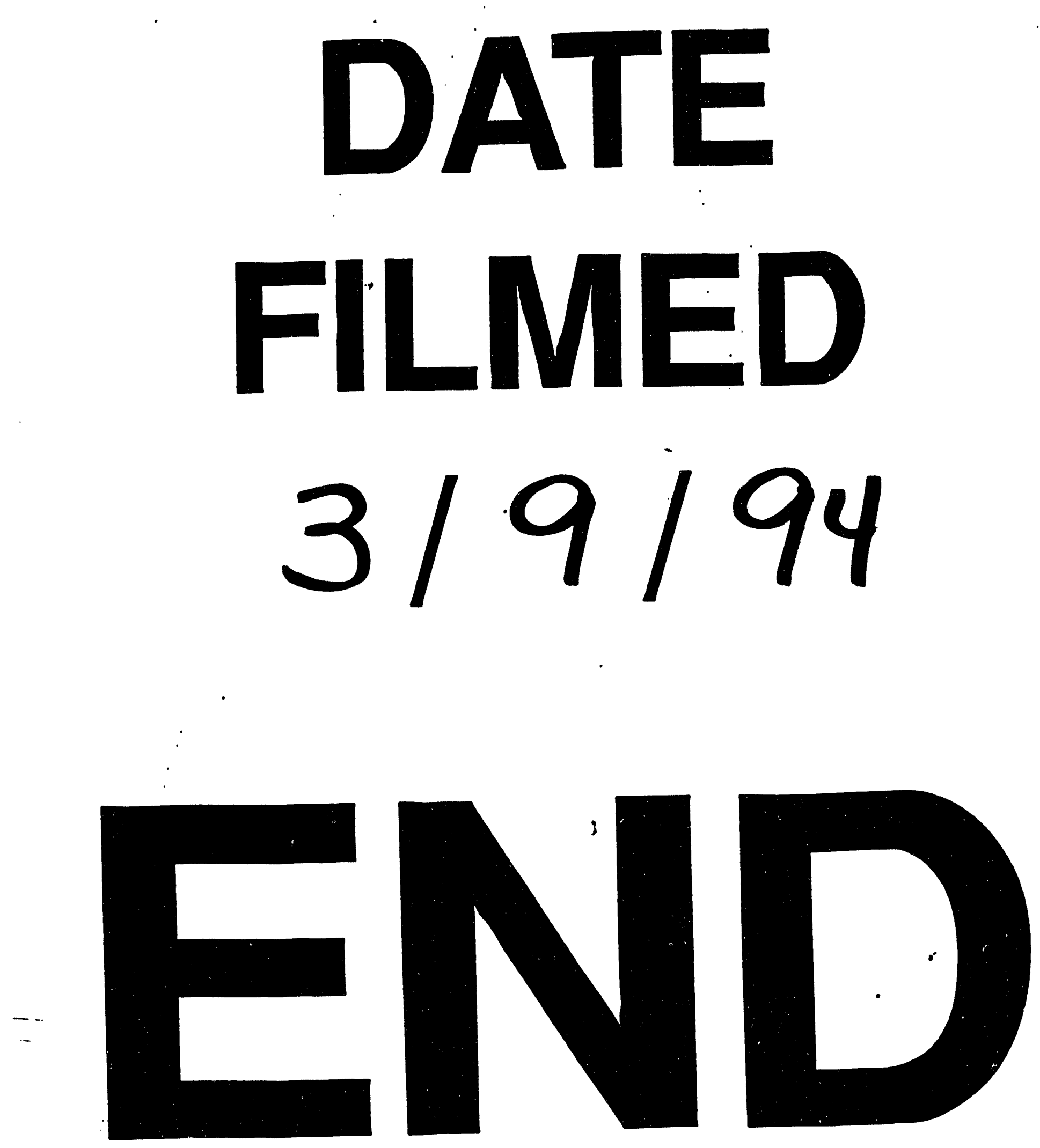